GRI-94/0038

\title{
PIPELINE CORRDORS THROUGH WETLANDS - IMPACTS ON PLANT COMMUNITIES: DEEP CREEK AND BRANDY BRANCH CROSSINGS, NASSAU COUNTY, FLORIDA
}

\section{TOPICAL REPORT}

(July 1992-October 1993)

\section{Prepared by}

L.M. Shem, G.D. Van Dyke,* and R.E. Zimmerman

Center for Environmental Restoration Systems

Energy Systems Division

Argonne National Laboratory 9700 South Cass Avenue

Argonne, Illinois 60439

\section{For}

\section{GAS RESEARCH INSTITUTE}

Contract No. 5088-252-1770

GRI Project Manager

Ted Williams

Environment and Safety Research Group

December 1994

* Van Dyke is affiliated with the Department of Biology, Trinity Christian College, Palos Heights, Illinois. 
LEGAL NOTICE. This report was prepared by Argonne National Laboratory as an account of work sponsored by the Gas Research Institute (GRI). Neither GRI, members of GRI, nor any person acting on behalf of either:

a. Makes any warranty or representation, express or implied, with respect to the accuracy, completeness, or usefulness of the information contained in this report, or that the use of any apparatus, method, or process disclosed in this report may not infringe privately owned rights; or

b. Assumes any liability with respect to the use of, or for damages resulting from the use of, any information, apparatus, method, or process disclosed in this report.

\title{
DISCLAIMER
}

\begin{abstract}
This report was prepared as an account of work sponsored by an agency of the United States Government. Neither the United States Government nor any agency thereof, nor any of their employees, makes any warranty, express or implied, or assumes any legal liability or responsibility for the accuracy, completeness, or usefulness of any information, apparatus, product, or process disclosed, or represents that its use would not infringe privately owned rights. Reference herein to any specific commercial product, process, or service by trade name, trademark, manufacturer, or otherwise does not necessarily constitute or imply its endorsement, recommendation, or favoring by the United States Government or any agency thereof. The views and opinions of authors expressed herein do not necessarily state or reflect those of the United States Government or any agency thereof.
\end{abstract}




\section{DISCLAIMER}

Portions of this document may be illegible in electronic image products. Images are produced from the best available original document. 


\begin{tabular}{|c|c|}
\hline \begin{tabular}{|l|l|l} 
REPORT DOCUMENTATION & 1. REPORT NO. \\
GAGI-94/0038 & 2
\end{tabular} & 3. Recipient's Accession No. \\
\hline 4. Title and Subtitle & 5. Report Date \\
\hline $\begin{array}{l}\text { Pipeline Corridors through Wetlands - Impacts on Plant Communities: Deep } \\
\text { Creek and Brandy Branch Crossings, Nassau County, Florida }\end{array}$ & 6. December 1994 \\
\hline $\begin{array}{l}\text { 7. Author(s) } \\
\text { L.M. Shem, G.D. Van Dyke, and R.E. Zimmerman }\end{array}$ & 8. Performing Organization Rept. No. \\
\hline $\begin{array}{l}\text { 9. Performing Organization Name and Address } \\
\text { Center for Environmental Restoration Systems } \\
\text { Energy Systems Division } \\
\text { Argonne National Laboratory } \\
9700 \text { South Cass Avenue } \\
\text { Argonne, Ill. } 60439\end{array}$ & $\begin{array}{l}\text { 10. ProjectTaskWork Unit No. } \\
\text { ACK } 85872 \\
\text { 71. Contract (c) or Grant (G) No. } \\
\text { (c) } 5088-252-1770 \\
\text { (G) }\end{array}$ \\
\hline $\begin{array}{l}\text { 12. Sponsoring Organization Name and Address } \\
\text { Environment and Safety Research Group } \\
\text { Gas Research Institute } \\
8600 \text { West Bryn Mawr Avenue } \\
\text { Chicago, Ill. } 60631\end{array}$ & $\begin{array}{l}\text { 13. Type of Report \& Period Covered } \\
\text { Topical Report } \\
\text { July 1992-October } 1993\end{array}$ \\
\hline
\end{tabular}

T. Supplementary Notes

16. Abstract (Limit 200 words)

The goal of the Gas Research Institute Wetland Corridors Program is to document impacts of existing pipelines on the wetlands they traverse. To accomplish this goal, 12 existing wetland crossings were surveyed. These sites varied in elapsed time since pipeline construction, wetland type, pipeline installation techniques, and rightof-way (ROW) management practices. This report presents the results of surveys conducted July 14-18, 1992, at the Deep Creek and the Brandy Branch crossings of a pipeline installed during May 1991 in Nassau County, Florida. Both floodplains supported bottomland hardwood forests. The pipeline at the Deep Creek crossing was installed by means of horizontal directional drilling after the ROW had been clear-cut, while the pipeline at the Brandy Branch crossing was installed by means of conventional open trenching. Neither site was seeded or fertilized. At the time of sampling, a dense vegetative community, made up primarily of native perennial herbaceous species, occupied the ROW within the Deep Creek floodplain. The Brandy Branch ROW was vegetated by a less dense stand of primarily native perennial herbaceous plants. Plant diversity was also lower at the Brandy Branch crossing than at the Deep Creek crossing. The results suggest that some of the differences in plant communities are related to the more hydric conditions at the Brandy Branch floodplain.

17. Document Analysis a. Descriptors

b. Identifiers/Open-Ended Terms

c. COSATI Field/Group

\begin{tabular}{|c|c|c|}
\hline $\begin{array}{l}\text { f8. Availability Statement } \\
\text { Release unlimited }\end{array}$ & $\begin{array}{l}\text { 19. Security class (this heport) } \\
\text { Unclassified }\end{array}$ & 21. No. of Pages \\
\hline & $\begin{array}{c}\text { 20. Security Class (This Page) } \\
\text { Unclassified }\end{array}$ & 22. Price \\
\hline
\end{tabular}




\section{Research Summary}

Title Pipeline Corridors through Wetlands - Impacts on Plant Communities: Deep Creek and Brandy Branch Crossings, Nassau County, Florida

Contractor Argonne National Laboratory

Principal Investigators

Report Period

Objective

Technical Perspective

\author{
L.M. Shem, G.D. Van Dyke, and R.E. Zimmerman
}

July 1992-October 1993

Document the historical impacts of pipeline rights-of-way (ROWs) on wetlands.

The impact of pipeline construction in wetlands is a very sensitive issue and one that is under strict regulatory control. Neither the natural gas industry nor the regulatory community has a documented basis to define the type, value, or environmental consequences of past pipeline activities in wetlands. This report is one of a series documenting these impacts. This data report is the result of field studies in two forested wetlands along the route of a pipeline installed one year prior to sampling. Pipeline installation at one site was by conventional open trenching, while installation at the other site was by directional drilling.

Results Observable impacts of the ROW on the natural communities at both sites were, except for minor impacts, limited to the ROW itself. The ROW at the Deep Creek site had been cleared of forest vegetation prior to being directionally drilled. The soil surface of the ROW was undisturbed, except for disturbances caused by heavy equipment used to remove timber and slash. Within 14 months, the ROW at this site supported a dense herbaceous vegetative community composed predominantly of native perennial species. Species richness in the ROW was greater than in the adjacent natural areas (NAs). Topography and hydrology of the ROW and the wetland appeared to be unmodified. At the Brandy Branch site, pipeline installation was by conventional trenching. At this site, there was more standing water on the ROW than in the adjacent NAs and ROW vegetation was less well-developed and contained fewer species than the vegetation on the ROW at the Deep Creek Site. Development of ROW vegetation at the Brandy Branch site appeared to be impeded by more standing water, unconsolidated soils, and a 
later final grading date, which resulted in less elapsed time between site closure and vegetative sampling. Differences in natural site hydrology account for at least some of the differences in vegetation development. The ROW at the Deep Creek site was well-drained for much of the growing season. The ROWs at both sites supported hydric vegetation.

Technical Approach

Project Implications
A relatively homogeneous study site was selected within a forested wetland occupying at least 200 meters along the ROW at each site. Data were collected on soils, hydrology, and plant cover from transect plots within both sides of the ROW and the NAs on either side of the ROW. Plant data were analyzed to determine similarities and differences between the two sides of the ROW and the two adjacent NAs.

This study shows that within one year after installation of the pipeline, the ROW through the forested wetland at the Deep Creek site had developed a dense and diverse stand of mostly native herbaceous plant species. Bahia grass, seeded on an adjacent upland, had become sufficiently established on the ROW within the wetland to constitute a dominant species. Some of the soil surface on the ROW remained unvegetated at the wetter Brandy Branch site. Standing water at this site had delayed final grading for approximately six months. Bahia grass, apparently from adjacent upland seeding, was also present on the ROW at this site. ROW vegetation at this site consisted of species with greater fidelity to wetlands than was characteristic of the species at the Deep Creek site. There had been no seeding, liming, or fertilization of the ROWs within these two wetlands. Both ROWs add to the species richness of the wetlands they traverse while providing a diversity of habitat and forest edge.

Ted A. Williams

GRI Project Manager

Environment and Safety Research Group 


\section{Contents}

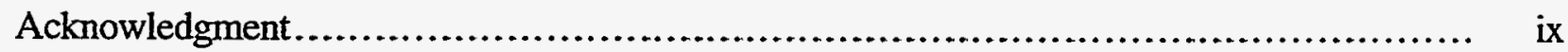

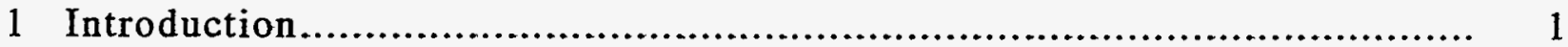

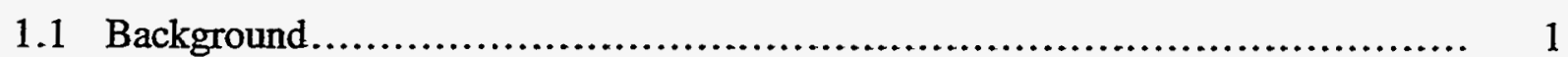

1.2 Goals and Objectives ...................................................... 2

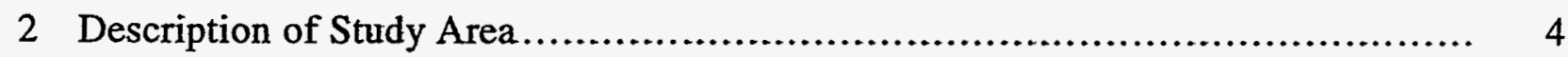

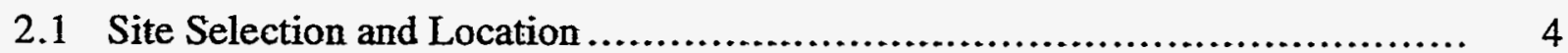

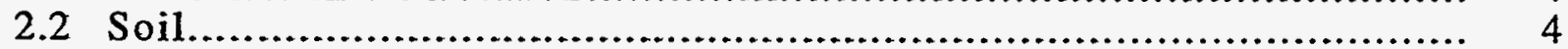

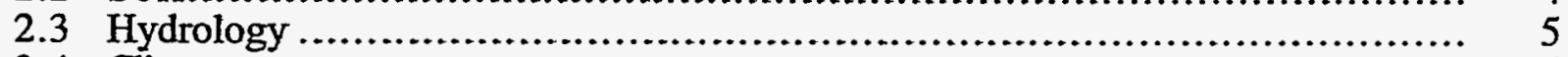

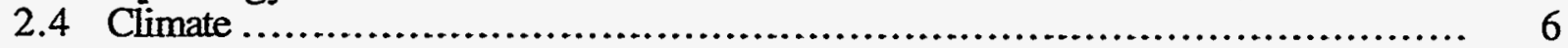

2.5 History and Management Practices ............................................. 6

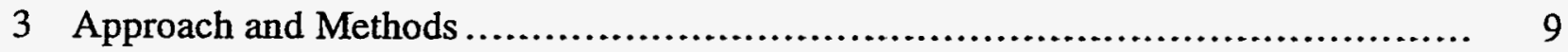

3.1 General Approach ........................................................... 9

3.2 Habitat Description ........................................................... 9

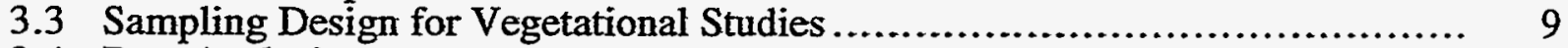

3.4 Data Analysis ......................................................... 12

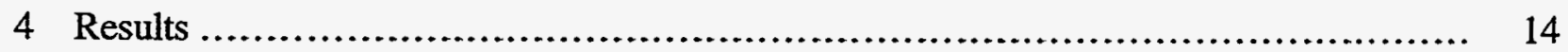

4.1 Deep Creek Study Site ............................................... 14

4.1.1 General Ecology ............................................................ 14

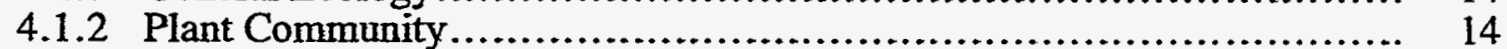

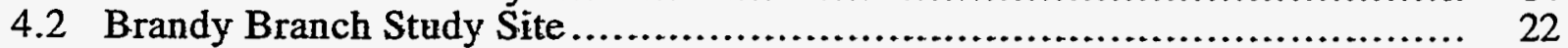

4.2.1 General Ecology ......................................................... 22

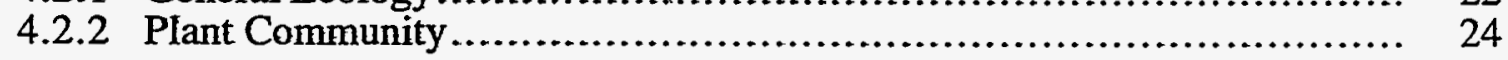

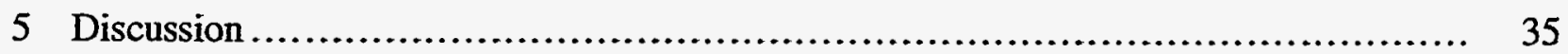

5.1 Deep Creek Study Site .................................................. 35

5.2 Brandy Branch Study Site ................................................. 36

5.3 Comparison of the Deep Creek and Brandy Branch Sites....................... 36

6 Summary and Conclusions.................................................... 38

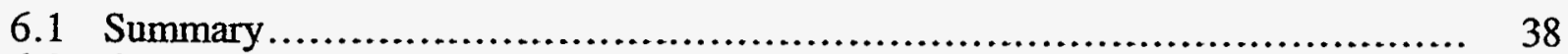

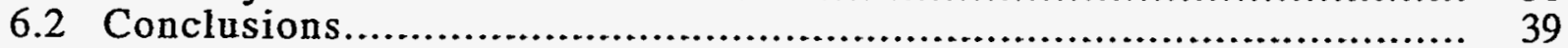

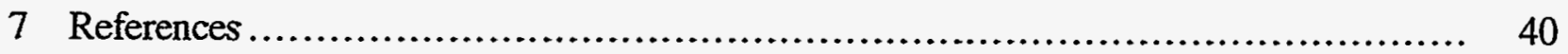

Appendix A: Definition of Jurisdictional Wetlands ............................... 41

Appendix B: Data Analysis — Definitions and Equations............................ 45

Appendix C: Plant Species List, Areal Coverage Data, and Species Distribution ....... 51 


\section{Figures}

1 Location of the Deep Creek and Brandy Branch Study Sites in

Nassau County, Florida.

2 Generalized Cross Section of the Deep Creek Study Site Showing the ROW, Pipeline Location, and Vegetation Types.............................. 10

3 Generalized Cross Section of the Brandy Branch Study Site Showing the ROW, Pipeline Location, and Vegetation Types...

4 Plan View of Study Sites Showing Transect Length and Spacing....

5 Location and Dimensions of Sampling Plots along One Transect

6 Number of Species in Each Wetland Indicator Category by Area

for the Deep Creek Site

7 Percent of Species in Each Wetland Indicator Category by Area for the Deep Creek Site

8 Number of Species in Each Wetland Indicator Category by Area for the Brandy Branch Site

9 Percent of Species in Each Wetland Indicator Category by Area for the Brandy Branch Site

A.1 Schematic Diagram of the Wetland Delineation Process.

\section{Tables}

1 Number of Plant Species by Wetland Indicator Category Found in the Study Plots in the NAs and the ROW at the Deep Creek Site

2 Number of Plant Species by Wetland Indicator Category Found in the Study Plots in the North and South Sides of the ROW at the Deep Creek Site

3 Number of Plant Species by Wetland Indicator Category Found in the NNA and SNA at the Deep Creek Site.

4 Dominant Species by Vegetative Stratum for Each Area at the Deep Creek Site

5 Coefficient of Community Values Comparing Similarity of Species Occurring in Study Plots at the Deep Creek Site.

6 Prevalence Index and Average Wetland Values for all Species and Dominant Species Found in the NAs and the ROW at the Deep Creek Site 


\section{Tables (Cont.)}

$7 \quad$ Number of Plant Species by Wetland Indicator Category Found in the Study Plots in the NAs and the ROW at the Brandy Branch Site

8 Number of Plant Species by Wetland Indicator Category Found in the Study Plots in the West and East Sides of the ROW at the Brandy Branch Site.

9 Number of Plant Species by Wetland Indicator Category Found in the Study Plots in the WNA and ENA at the Brandy Branch Site

10 Dominant Species by Vegetative Stratum for Each Area at the Brandy Branch Site

11 Coefficient of Community Values Comparing Species Occurring in Study Plots at the Brandy Branch Site.

12 Prevalence Index and Average Wetland Values for All Species and Dominant Species in the NAs and the ROW at the Brandy Branch Site

C.1 Plant Species List for the Deep Creek Site

C.2 Cover Estimates for Each Species by Stratum, Deep Creek Site

C.3 Average Percent Cover, Absolute Frequencies, and Distribution of Species by Stratum, Deep Creek Site.

C.4 Plant Species List for the Brandy Branch Site

C.5 Cover Estimates for Each Species by Stratum, Brandy Branch Site 66

C.6 Average Percent Cover, Absolute Frequencies, and Distribution of Species by Stratum, Brandy Branch Site 


\section{Acknowledgment}

The authors would like to thank John Bailey, Center for Wetlands, Phelps Laboratory, University of Florida, Gainesville, for verifying the identifications of the plant species found at the study sites in Nassau County, Florida. 


\title{
Pipeline Corridors through Wetlands - Impacts on Plant Communities: Deep Creek and Brandy Branch Crossings, Nassau County, Florida
}

by

\author{
L.M. Shem, G.D. Van Dyke, and R.E. Zimmerman
}

\section{Introduction}

\subsection{Background}

Pipelines for the distribution of natural gas traverse all types of terrain, including wetlands. Prior to the wetlands regulatory climate of the late 1980s and the early 1990s, the construction of right-of-way (ROW) corridors through wetlands was often welcomed by landowners and local communities; ROW corridors opened up wetlands, thereby providing public access. With the promulgation of more stringent regulations related to development activities (including no-net-loss wetland policies), an assessment of the historical impacts of pipeline ROWs through wetlands is needed to evaluate construction and reclamation methods, assist in future permit application processes, and evaluate future construction costs.

The Gas Research Institute (GRI) Wetland Corridors Program was designed to evaluate impacts of gas-pipeline construction and subsequent maintenance on wetlands. The data gathered through this GRI program provide a better understanding of the type, degree, and duration of impacts of various pipeline-construction techniques. This information will enable the industry to evaluate current construction practices and provide factual input to regulatory bodies.

Careful evaluation of the impacts of pipeline installation on wetlands is necessary because specific impacts may be beneficial to some plant and/or animal species and detrimental to others. Some impacts may appear to be detrimental when, in fact, they improve conditions for certain sensitive species or provide for greater diversity of species and habitat.

The initial questions addressed by the GRI Wetland Corridors Program are as follows:

1. Do ROW construction and/or management practices lead to differences in ROW plant communities with respect to adjacent wetland communities?

2. Does the ROW alter the diversity of the adjacent wetland community? If so, how far do the impacts extend?

3. Does the ROW enhance species diversity of the wetland? 
4. Are there ROW construction and management practices that can enhance the positive contributions of ROWs to wetlands and minimize detrimental impacts?

Answers to these broad questions will provide information related to a number of more specific questions. Data on the type of plant communities that develop on ROWs in various wetlands when specific pipeline construction and management practices are utilized and comparison of the ROW plant communities with the plant communities in areas adjacent to the ROW will provide a basis for comparing environmental impacts of previous and current construction and management practices. Valuable data for such comparisons include numbers of plant species present, species that are dominant, percentage of the species that are native to the area, and fidelity of the plants to wetlands. Other measures of the quality of species present are also valuable, but those data are not available at present.

Concern exists as to whether pipeline corridors provide avenues of access for nonnative and invasive plants. Whether such plants become established along pipeline ROWs and from there invade adjacent areas, and the extent to which such invaders modify the plant communities in adjacent areas, are important to determining potential impacts of pipelines on wetlands.

Potential positive impacts are also important to assess. The degree to which ROWs provide habitat for rare or endangered species and other desirable species that are poorly represented in the adjacent areas is important information. Assessments of impacts of pipeline corridors on wetlands should also include the contribution of corridors to both plant and animal species diversity.

Answers to the above questions will assist the industry and regulatory agencies in evaluating current installation and management practices and making modifications that are beneficial to wetland quality enhancement.

\subsection{Goal and Objectives}

The goal of the GRI Wetland Corridors Program is to document impacts of existing pipelines on the wetlands they transverse. To accomplish this goal, 12 existing wetland crossings were surveyed. The sites evaluated differed in years since pipeline installation (ranging from 8 months to 31 years), wetland type, installation technology used, and management practices. Each wetland survey had the following specific objectives:

- Document vegetative communities existing in the ROW and in adjacent wetland communities;

- Evaluate similarities and differences between the plant communities in the ROW and in the adjacent wetland communities; 
- Document qualitative changes to the topography, soils, and hydrology attributable to ROW construction; and

- Identify impacts caused by ROW construction on rare, threatened, endangered, or sensitive species.

These individual wetland objectives were fulfilled by the collection and analysis of field data and the presentation of those data and their analysis in nine individual site reports. An upcoming summary report further synthesizes and interprets the data from all individual sites.

This report is a data report of a field survey conducted over the period of July 13-16, 1992, at two bottomland, hardwood wetland sites along a pipeline ROW near the town of Baldwin, in Nassau County, Florida. The pipeline was installed approximately one year prior to this survey. 


\section{Description of Study Area}

\subsection{Site Selection and Location}

Personnel from a local gas pipeline company assisted a team from Argonne National Laboratory (ANL) in selecting areas classified as "Jurisdictional Wetlands" under Section 404 of the Clean Water Act. Several wetlands crossings were identified along a recently installed pipeline that extends across the southwest portion of Nassau County in northeast Florida and feeds into lines serving Jacksonville. Field visits were made to several of these wetland crossings. Two sites were selected so that (1) the effects of two different pipeline installation technologies directional horizontal drilling and open trenching - on the reestablishment of vegetation on the ROW could be compared and (2) the impacts on adjacent wetland areas undisturbed by pipeline installation could be assessed. At each site, the wetland paralleled at least $200 \mathrm{~m}^{*}$ along the length of the ROW and extended $50 \mathrm{~m}$ on both sides of the ROW, from its center. The natural vegetation at both sites was a second growth, predominantly hardwood, bottomland forest.

One of the selected sites was the pipeline crossing of the Deep Creek floodplain wetland, within which the pipeline was installed by means of horizontal drilling. The other site was the crossing of the eastern drainage into the Brandy Branch Swamp, within which the pipeline was installed by means of open trenching. Figure 1 shows that the sites are located approximately $6 \mathrm{mi}(10 \mathrm{~km})$ apart in the southwest portion of Nassau County. Deep Creek is located approximately $3.5 \mathrm{mi}(5.6 \mathrm{~km})$ northwest of Baldwin, just west of state highway 90 . Brandy Branch is located approximately $5 \mathrm{mi}(8 \mathrm{~km})$ north of Baldwin, just west of state highway 200 . Both sites are palustrine forested wetlands (Cowardin et al. 1979).

\subsection{Soil}

The soils at the two sites are mapped as Ellabelle soils (Soil Conservation Service [SCS] 1991a). Ellabelle soils are classified as hydric soils (SCS 1991b). The Ellabelle soils are siliceous, thermic Arenic Umbric Paleaquults (SCS 1991b), characterized by mucky fine sand and subject to frequent flooding for long periods most years. Ellabelle soils are found in nearly level, poorly drained drainageways. Typically, the surface of the Ellabelle soil is about 12 in. thick, with the upper portion made up of black, mucky fine sand and the lower portion made up of very dark gray fine sand. The subsurface is made up of fine sand, with a gray upper portion and a grayish-brown lower portion. The subsoil is a dark gray sandy loam in the upper portion, a grayish-brown sandy clay in the middle portion, and a greenish-gray sandy clay in the lower portion.

\footnotetext{
* Measurements are given in metric units except where they were actually taken in English units; in these cases, metric equivalents are given in parentheses.
} 


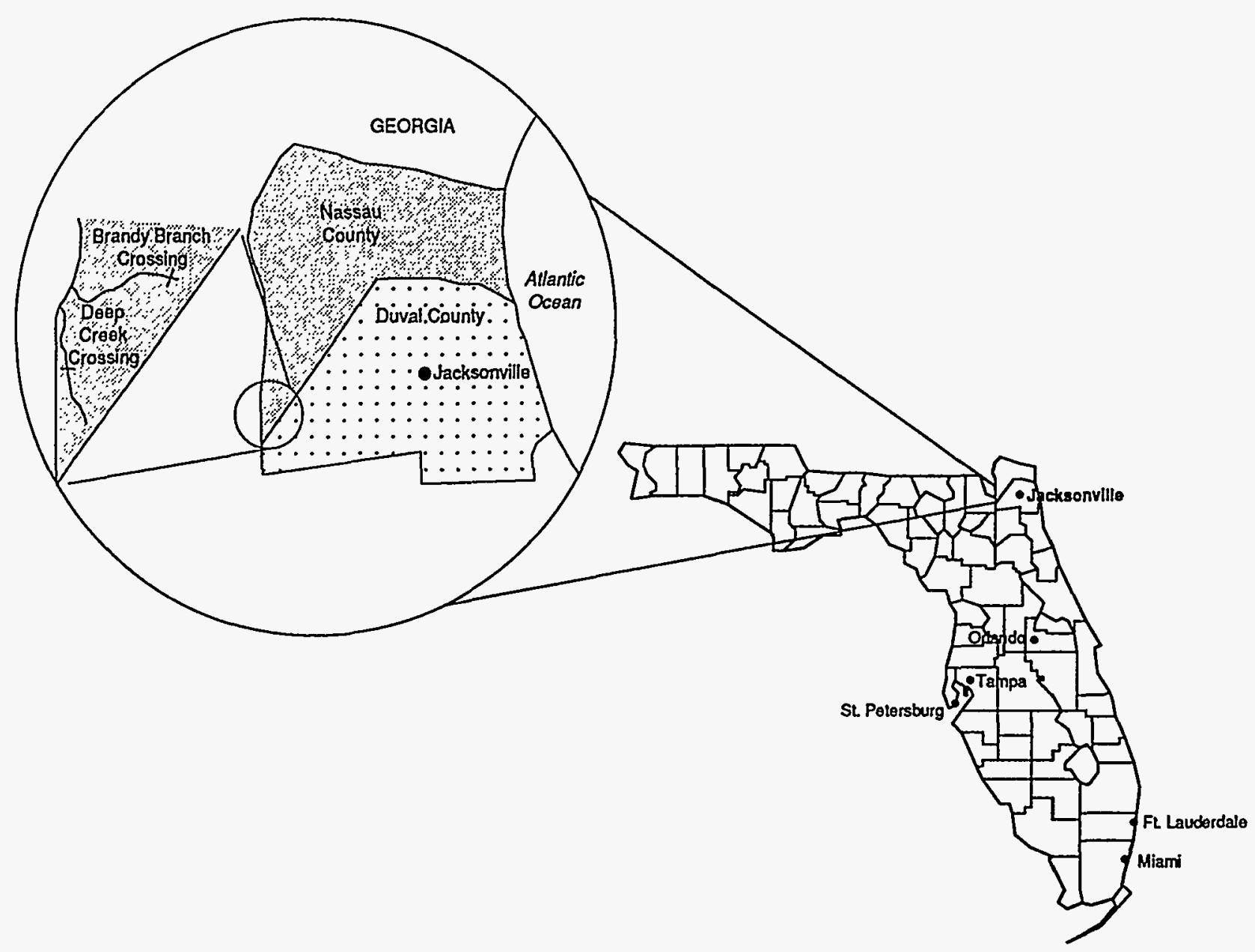

FIGURE 1 Location of the Deep Creek and Brandy Branch Study Sites in Nassau County, Florida

The permeability of the Ellabelle soil is moderately rapid in the surface and subsurface strata and moderately slow in the subsoil. The seasonal high water table is within 12 in. of the surface for three to six months of the year. Soil fertility is low.

Areas with Ellabelle soils are generally woodlands that are composed of a pond pine, sweetgum, blackgum, water oak, bald cypress, and water tupelo overstory. The understory includes fetterbush lyonia, red maple, southern bayberry, giant gallberry, and sweetbay. Common grasses are plumegrass, longleaf uniola, and sedge.

\subsection{Hydrology}

The Deep Creek study site is located on the floodplain of Deep Creek, approximately $2.3 \mathrm{mi}(3.7 \mathrm{~km})$ south of its confluence with the Saint Mary's River. Although Deep Creek is a relatively large permanent stream, it is well within its banks for most of the year. Limited seasonal flooding is caused by high rainfall events and can occur during months of heavy rainfall. The 
study site is within the floodplain on the east side of the main channel and includes a smaller channel. Although the smaller channel is 4-5 ft $(1.2-1.5 \mathrm{~m})$ deep, it had less than $1 \mathrm{ft}(0.3 \mathrm{~m})$ of water at the time of field sampling.

The Brandy Branch study site encompasses the upper portion of Brandy Branch Swamp, which is drained by Brandy Branch Creek. Several channels cross the ROW in this area. The largest channel is $5-10 \mathrm{ft}(1.5-3.0 \mathrm{~m})$ wide and 3-4 $\mathrm{ft}(0.9-1.2 \mathrm{~m})$ deep, and the banks were $2-3 \mathrm{ft}(0.6-0.9 \mathrm{~m})$ above water level at the time of field investigations. The study site was south of this channel and just north of a second channel, which was 5-10 $\mathrm{ft}(1.5-3.0 \mathrm{~m})$ wide but only 2-4 $\mathrm{ft}(0.6-1.2 \mathrm{~m})$ deep; this channel had low banks that were less than $1 \mathrm{ft}(0.3 \mathrm{~m})$ above water level. A third channel (best described as a slough) crossed the study site just south of its center. This channel had no defined banks - it consisted of shallow standing and flowing water on the ROW. Little water occurred west of the ROW, although a well-defined drainage channel occurred east of the ROW. This area was described in the wetland crossing plan as a high-quality wetland.

\subsection{Climate}

The climatic information presented here is taken from the Soil Survey of Nassau County, Florida (SCS 1991a). Nassau County has a climate of long, warm, humid summers and mild winters. Average monthly temperatures in the summer are around $80^{\circ} \mathrm{F}\left(27^{\circ} \mathrm{C}\right)$, and the high temperature rarely exceeds $96^{\circ} \mathrm{F}\left(36^{\circ} \mathrm{C}\right)$. In the winter, average monthly temperatures are around $56^{\circ} \mathrm{F}\left(13^{\circ} \mathrm{C}\right)$; low temperatures rarely dip below freezing.

Average annual precipitation recorded at the Jacksonville International Airport, approximately $20 \mathrm{mi}(32 \mathrm{~km})$ to the east, is $54.47 \mathrm{in} .(138 \mathrm{~cm})$. Approximately $65 \%$ of the annual rainfall occurs between June and October. During this period, showers and thunderstorms can be heavy; rainfall rates of 2 to $3 \mathrm{in} . \mathrm{h}(5.1$ to $7.6 \mathrm{~cm} / \mathrm{h})$ have been recorded. Average monthly rainfall for the summer months is between 5 and 8 in. $(12.7$ and $20.3 \mathrm{~cm})$, and that for the winter months is from 2 to $3.6 \mathrm{in}$. $(5.1$ to $9.1 \mathrm{~cm})$. Snowfall is very rare and generally melts as it hits the ground. Tropical storms can affect the area between June and mid-November. Hurricaneforce winds (up to $75 \mathrm{mph}$ ) occur about once in 50 years.

Extended dry periods can occur at any time of the year. They are most common in the spring and fall. Dry periods in the spring (April and May) are generally shorter than those in the fall, but they are more severe because temperatures are higher in the spring than in the fall and because plants need more moisture after winter for spring growth.

\subsection{History and Management Practices}

Area History. Both sites support forests consisting of bottomland hardwoods, pines, and bald cypress. Although no records of recent logging could be found for either site (and remnants 
of cut stumps were not present in the uncut forest), it is likely that at least some logging has occurred at each site. The forest at the Brandy Branch site had larger trees and a less dense understory than did the forest at the Deep Creek site.

Pipeline Construction. The pipeline was constructed during 1991. According to the construction training documents, workers were required to participate in preconstruction seminars at which construction techniques and practices were discussed. Wetland construction requirements dealing with clearing, construction, soil replacement, erosion, and turbidity control were addressed in the seminar. Each wetland to be crossed by the pipeline was specifically discussed.

It is assumed that stipulated procedures were followed. If so, clearing, excavation, soil replacement, and construction-equipment access were limited to the 50-ft (15-m) ROW. Equipment traffic within wetlands was kept to a minimum. Woody vegetation was cleared from the ROW, by hand, to near ground level. Low stumps and root systems were left intact, except where the pipeline trench was excavated or where these plant parts had to be removed to enable access by construction equipment. Bulldozers were used to remove logs and debris from the wetlands. Immediately after clearing, turbidity curtains and staked hay bales were used upstream and downstream of the work area for all stream, river, or flowing wetland crossings to prevent suspended materials from flowing downstream. Staked hay bales were employed along all stream banks in the wetland areas for erosion control. Silt fences were placed along both edges of the ROW and extended $20 \mathrm{ft}$ beyond the limits of the wetland. Staging areas were limited to a maximum size and were at least $50 \mathrm{ft}$ from the edge of the wetland. Silt fences were used between adjacent uplands and the wetland to prevent the erosion of disturbed soils into the wetland. Refueling and other activities involving hazardous substances were kept at least $100 \mathrm{ft}$ from the edge of the wetland.

During February and March of 1991, the ROW was cleared along the pipeline route. After clearing of the ROW at the Deep Creek site, directional drilling was used to install the pipeline through the wetland. Conventional construction techniques involving trenching and backfilling were used at the Brandy Branch site. At Brandy Branch, the east side of the ROW was used as the working side, and the pipeline was installed approximately $15 \mathrm{ft}(4.5 \mathrm{~m})$ from the west edge of the ROW. At the time of pipeline installation, this area was covered by shallow standing and running water. Operators of construction equipment used mats and corduroy to help them navigate the standing water and soft soil of this site. An attempt was made to salvage the upper one foot of top soil for replacement at the surface while backfilling the trench. However, because of the wet conditions during construction, this activity proved to be impractical. Water was pumped from the trench before backfilling and filled to original grade (as near as possible).

Although the pipeline had been installed through both sites by May 1991, final cleanup of the Brandy Branch site was delayed until December 1991 because of high water levels at the time of pipeline installation. Cleanup tasks included pulling stumps, removing silt fences from the ROW, and final grading. 
Postconstruction Maintenance. The two wetland study sites were allowed to revegetate naturally - no seeding, liming, or fertilizing was performed. Maintenance plans require that all invasive plant species be hand-pulled one year after the completion of construction; this practice will be a one-time event. Erosion-control devices will be left in place until vegetation stabilizes the soils within the sites. The ROW within the wetlands will not be mowed. Selective hand-cutting of trees will be done to maintain access to the pipeline and to comply with U.S. Department of Transportation (DOT) surveillance requirements under 49 CFR 192.

Uplands adjacent to the wetlands were stabilized by fertilizing with 13-13-13 fertilizer at a rate of $100 \mathrm{lb} /$ acre and by seeding with bahia grass (Paspalum notatum), Bermuda grass (Cynodon dactylon), and panic grass (Panicum fasiculatum) at rates of 100, 50, and $20 \mathrm{lb} / \mathrm{acre}$, respectively. 


\section{Approach and Methods}

\subsection{General Approach}

The primary objectives listed in the Introduction (Section 1.2) provided the general guidelines for this study. To allow comparison of results across sites, methodologies for site reconnaissance, vegetation data collection, and data analysis used at this site were similar to those used at the other sites. Because both of these two study sites were located within forested wetlands having well-developed canopies, sampling techniques were adapted to provide basal areas of trees and numbers of vines per plot.

\subsection{Habitat Description}

General data on the habitats of the sites, including topography, water levels, direction of water flow, soil conditions, and structure of the plant communities, were recorded on the basis of the general reconnaissance of the sites. Soil characteristics (as observed by means of a hand auger) were compared with those listed for Ellabelle soils, as mapped for each site in the Soil Survey of Nassau County, Florida (SCS 1991a).

ROW boundaries were identified on the basis of construction plan information and field observations. Figure 2 shows a generalized cross-sectional profile of the Deep Creek site, including the ROW, natural vegetation, and location of the pipeline. Figure 3 shows a similar generalized cross-sectional profile of the Brandy Branch site.

\subsection{Sampling Design for Vegetational Studies}

The design for sampling was similar for each of the two study sites. Four areas were defined on the basis of their relationship to the midline of the ROW. These four areas consist of the two sides of the ROW and the two adjacent natural areas (NAs), the wetlands undisturbed by pipeline installation, on either side of the ROW. This definition of areas allows comparisons between the two vegetative communities in the NAs on either side of the ROW, the vegetative communities developing on the two sides of the ROW, and the vegetative communities developing on the ROW and those occurring in the NAs. For convenience, the four areas are designated at each site by the direction in which they lie from the midline of the ROW.

Transects. At each site, five starting points for the transects were established at 30-m intervals along the midline of the ROW. Transects were established perpendicular to the midline of the ROW, extending $30 \mathrm{~m}$ in either direction from each transect starting point. Figure 4 illustrates the general layout of these transects for both study sites. Directional orientation is not given in 


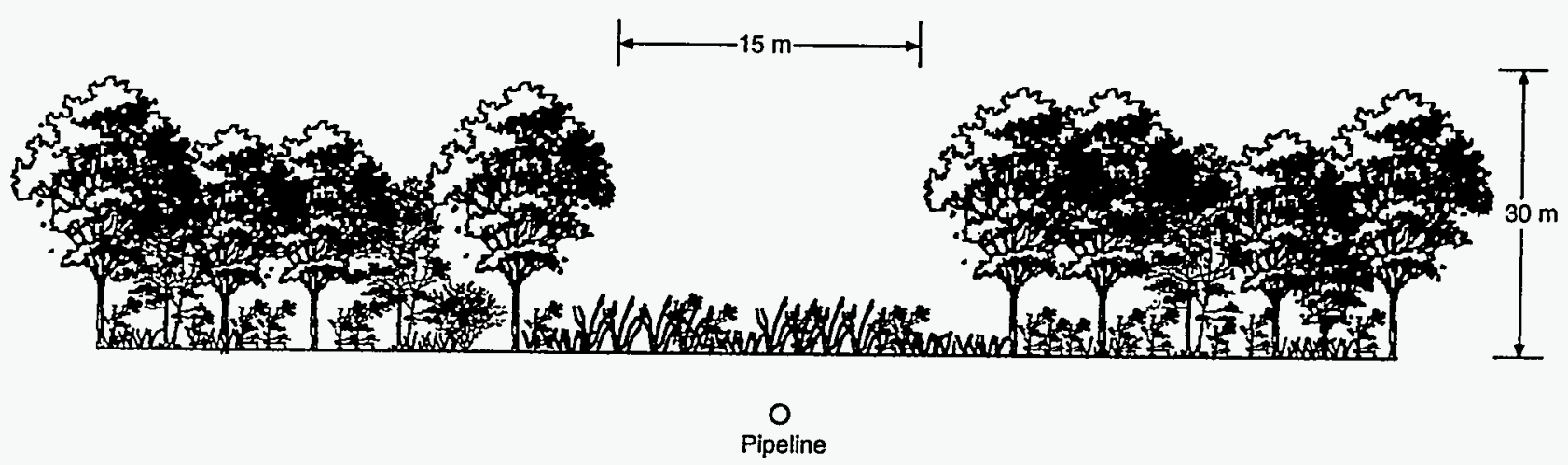

FIGURE 2 Generalized Cross Section of the Deep Creek Study Site Showing the ROW, Pipeline Location, and Vegetation Types

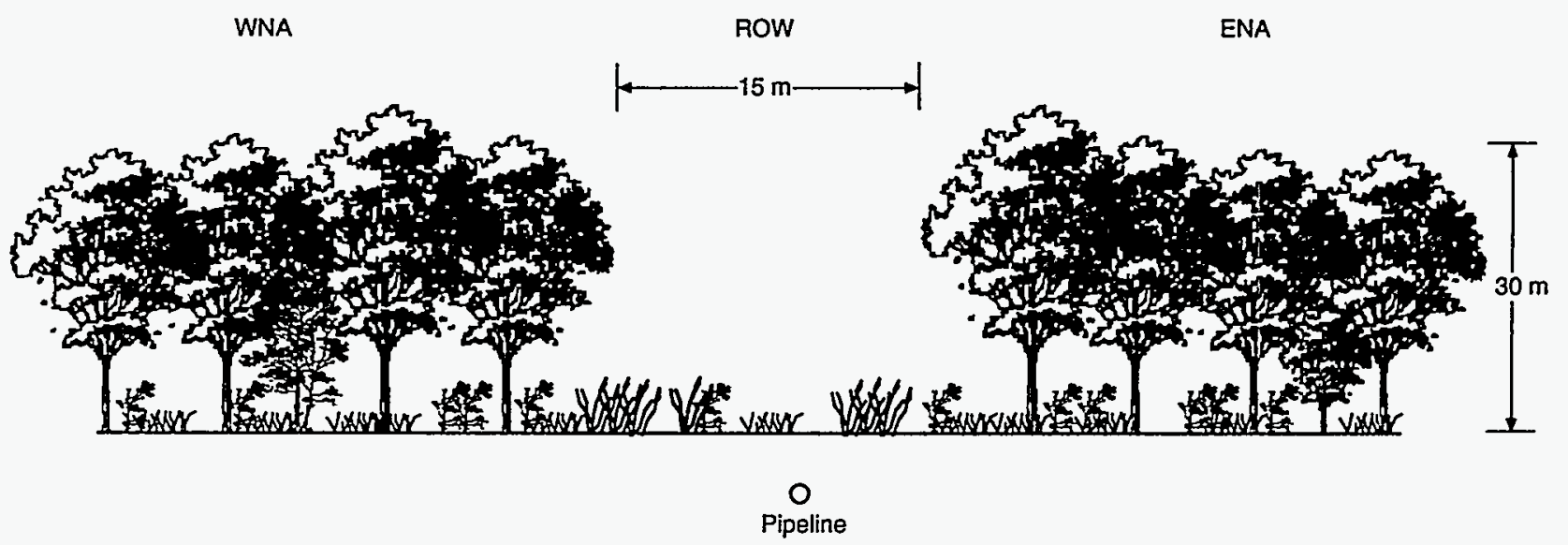

FIGURE 3 Generalized Cross Section of the Brandy Branch Study Site Showing the ROW, Pipeline Location, and Vegetation Types

Figure 4 because the ROW at the Deep Creek site runs east to west, while the ROW at the Brandy Branch site runs north to south.

Four $2 \mathrm{~m} \times 5 \mathrm{~m}$ sampling plots were established along each transect for sampling the herb stratum. The two plots on the ROW extended from the center of the ROW, $5 \mathrm{~m}$ along the transect in either direction. The two plots in the NAs extended along the transects, and each plot began $17.5 \mathrm{~m}$ from the center of the ROW and extended $22.5 \mathrm{~m}$ from the center of the ROW. Shrub, vine, sapling, and tree data were collected in the NAs. To collect these data, $10 \mathrm{~m} \times 20 \mathrm{~m}$ plots were established along each transect, beginning $10 \mathrm{~m}$ from the center of the ROW and extending to $30 \mathrm{~m}$ from the center of the ROW. Figure 5 illustrates the layout of plots along each transect in relationship to the pipeline and the edges of the ROW. The transect lines delineated the eastern edges of the plots at the Deep Creek site, while the transect lines delineated the southern edges of the plots at the Brandy Branch site. 


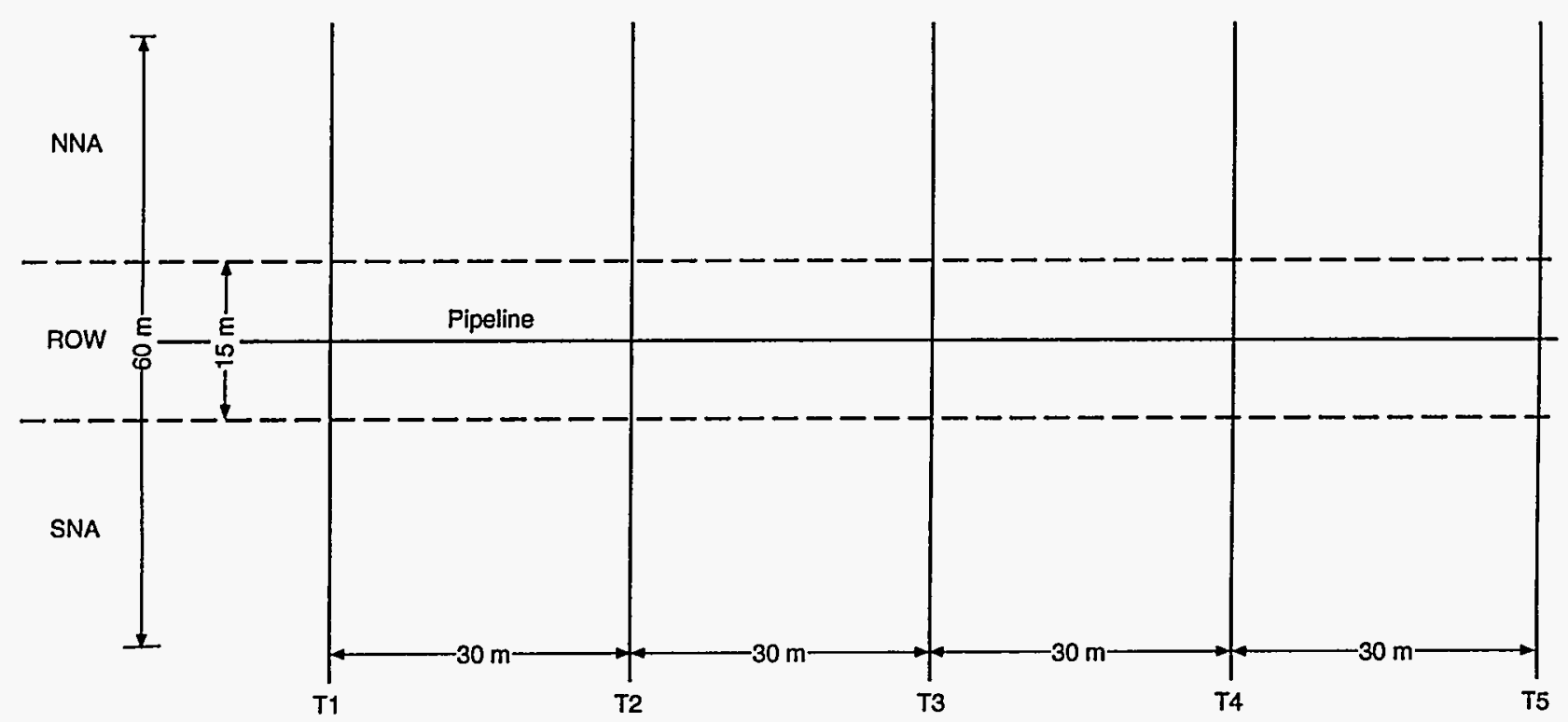

FIGURE 4 Plan View of Study Sites Showing Transect Length and Spacing

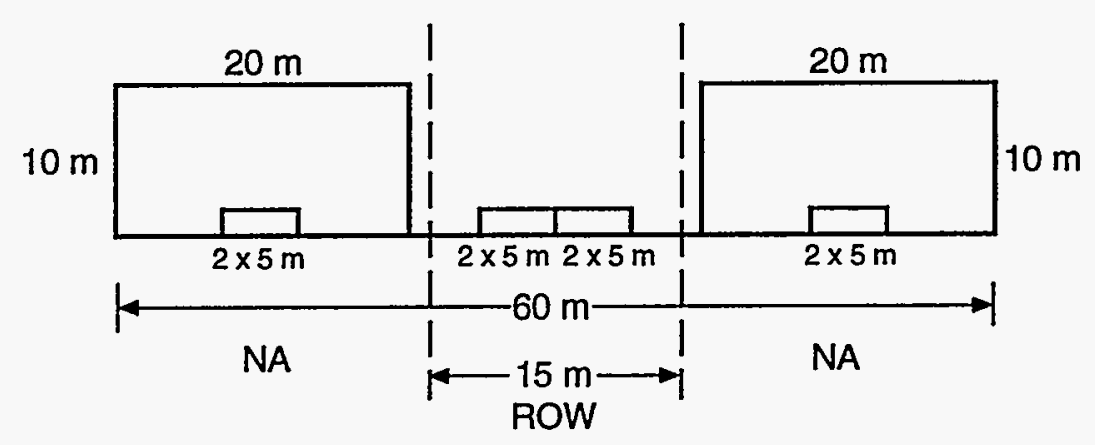

FIGURE 5 Location and Dimensions of Sampling Plots along One Transect

Sampling Procedures. Vegetational data were collected for all plots at each site. Two specimens of each plant species, except rare or endangered species, found on or near the plots were collected as voucher specimens. Common names for the plants, wetland indicator categories, life-forms, and the origin of each species were derived from Reed (1988).

Vegetational data were collected by recording separate data for each species within the sampling plots. Visual estimates of areal cover were made separately for the herb, shrub, and sapling strata. Diameter at breast high (dbh) was recorded for each tree that occurred in each large plot. Definitions of strata and trees are given in the 1989 Federal Manual (FICWD 1989). The herb stratum is defined as herbaceous plants, including graminoids, forbs, ferns, herbaceous vines, and woody species under $3 \mathrm{ft}(0.91 \mathrm{~m})$ in height. The shrub stratum includes multistemmed bushy shrubs, small trees, and saplings between 3 and $20 \mathrm{ft}(0.91$ and $6.1 \mathrm{~m})$ in height. Saplings are defined as having a dbh of 0.4 to 4.9 in. $(1.0$ to $12.4 \mathrm{~cm})$ and exceeding $20 \mathrm{ft}(6.1 \mathrm{~m})$ in height. Trees are defined as having a dbh of greater than or equal to $5.0 \mathrm{in}$. 
$(12.7 \mathrm{~cm})$ and exceeding $20 \mathrm{ft}(6.1 \mathrm{~m})$ in height. Numbers of vines, rather than estimates of areal cover, were recorded by species occurring in each large plot in the NAs; no accurate estimate of areal cover was possible because vine foliage interspersed with the canopy. Estimates of surface area were also recorded for exposed disturbed soil that occurred in ROW plots at Brandy Branch.

\subsection{Data Analysis}

Analyses of vegetative data collected from sampling plots for all 17 sites studied as part of the GRI Wetland Corridors Program were consistent. Analyses focused on comparing the plant communities on the ROW with those in the NAs and determining hydrophytic characteristics of the plant communities in each area. Particular attention was given to dominant species because they are used in several wetland delineation methods. Although the number of species dominant, species richness, and the variety of plant life-forms present are all aspects of community diversity, no diversity indices were calculated. Diversity indices that use coverage values as measures of species importance were considered, but they were judged inappropriate because of differences in the number of strata in the ROW and NAs for the sites included in the Wetland Corridors Program and because coverage values are not additive across strata.

Species Richness, Wetland Indicator Categories, and Species Characteristics. The total number of species present (species richness) was determined for each side of the ROW, for the total ROW, for each NA, and for the NAs combined. Wetland indicator categories (Reed 1988) were identified for each species in the study plots. These categories are defined in Appendix B, Section B.1. The number of species in each category was determined for each area by stratum and for all strata combined. Because one plant species could occur in any or all strata, when data from different strata were combined, each species was considered only once, independent of the number of strata in which it occurred. Species characteristics, including lifeforms and origins, were also determined from Reed (1988). Symbols for life-forms and species origins are given in Appendix B, Section B.2.

Dominant Species. The definition of and methodology for the determination of dominant species in this study were taken from the 1989 Federal Manual (FICWD 1989). In the manual, dominance refers "strictly to the spatial extent of a species that is directly discernible or measurable in the field," as opposed to number of individuals present. Using this definition, dominant species were identified by plant stratum, rather than by total community. For each area, the dominant species were determined for each stratum by ranking each species in a plant stratum in descending order relative to total areal coverage of all plants in that stratum. The highest ranking species, which make up $50 \%$ of the total areal coverage or half of the total relative percent coverage (RPC), are the dominant species for that stratum. Any remaining species with $20 \%$ or more RPC are also considered dominant. 
Community Similarity Indices. Sørensen's coefficient of community index $\left(\mathrm{CC}_{\mathrm{s}}\right)$ was used to measure similarity between vegetative communities (Brower, Zar, and von Ende 1990). This index uses the following formula:

$$
\mathrm{CC}_{s}=2 \mathrm{c} /(\mathrm{a}+\mathrm{b})
$$

where
$\mathrm{a}=$ the number of species in community $\mathrm{A}$,
$\mathrm{b}=$ the number of species in community $\mathrm{B}$, and
$\mathrm{c}=$ the number of species in common between communities $\mathrm{A}$ and $\mathrm{B}$.

A $\mathrm{CC}_{s}$ value of 1.00 indicates $100 \%$ similarity in species composition between communities A and B. A value of 0.00 represents no species in common. Community similarity indices that use coverage values as measures of species importance were considered, but they were judged inappropriate because of differences in the strata present in the plant communities on the ROW compared to those in the NAs and because of the nonadditive characteristic of coverage data.

Comparisons were made between the combined ROWs and combined NAs, the two portions of the ROW, each portion of the ROW and its adjacent NA, and the two NAs.

Prevalence Index Values. Prevalence index values (PIVs) were calculated according to methods outlined in the 1989 Federal Manual (FICWD 1989), substituting RPC data from quadrat coverage estimates for relative frequencies from intercept data. This substitution is logical because both relative frequency and RPC are estimates of relative coverage (Bonham 1989). The PIV is an average wetland indicator value ranging from 1.0 to 5.0 and weighted by the RPC. Because areal coverage was determined by stratum, the PIVs were calculated for each area by stratum only. The average RPCs for each species in the five plots in each area were used in calculating the PIV for the area. The equation for calculating a PIV is presented in Appendix B, Section B.3.

Average Wetland Values. Average wetland values (AWVs) (Zimmerman et al. 1991) were calculated for the species in each of the five areas. This index is an average of the wetland indicator values for all plants present. It differs from the PIV in that it is not weighted by RPC; rather, all plants present are represented equally, regardless of their frequency of occurrence. Because areal coverage is not considered, the calculation of an index value is not restricted to one vegetative stratum. An overall site AWV was determined, as well as values for each stratum. See Appendix B, Section B.4, for the equation. 


\section{Results}

Results of field investigations are presented separately for each site. Section 4.1 presents the results from the Deep Creek study site, and Section 4.2 presents those from the Brandy Branch study site. Subsections summarize observations from the general reconnaissance of both sites and vegetative data from plot sampling. The analysis of vegetative data is also presented.

\subsection{Deep Creek Study Site}

\subsubsection{General Ecology}

The Deep Creek study site was located on the eastern portion of the floodplain of Deep Creek. The site extended from approximately $20 \mathrm{~m}$ east of the main channel to $30 \mathrm{~m}$ from the eastern edge of the floodplain. A small secondary stream channel crossed the ROW between transects 4 and 5. Within the ROW, this channel consisted of a steep-sided ravine, 3-5 m wide and about $1 \mathrm{~m}$ deep, containing a small stream that was less than $1 \mathrm{~m}$ wide and $50 \mathrm{~cm}$ deep at the time of sampling. This stream meandered considerably on either side of the ROW, creating steep outer banks and small inner mud flats.

The vegetation of the floodplain within the NAs of the study site consisted of bottomland forest (with a nearly closed canopy) made up of sapling, shrub, and herb strata, each of which had less than $50 \%$ total areal cover. Woody vines ascending into the canopy were common. Canopy trees were mostly $15-25 \mathrm{~m}$ tall. Bald cypress trees were most abundant adjacent to the secondary stream channel. This floodplain forest extended to the south and north, well beyond the study site.

Soil samples, which were taken with a hand auger at the ends of the transects and where transects crossed the edges of the ROW, revealed profiles, textures, and colors that fit the general description of Ellabelle soils. Water table levels were below the 36-in. (0.91-m) depth that was attainable with the hand auger.

\subsubsection{Plant Community}

Appendix C presents field data on the vegetative communities in the ROW and in the NAs. Table C.1 lists plants found in this site by scientific names and authorities and gives common names, wetland indicator categories, life-forms, and origin, as determined from Reed (1988). Table C. 2 is a compilation of the field plot data, listing the percent areal cover for each species occurring within each sample plot. Table C.3 summarizes the distribution of each species by average percent areal cover and frequency (the number of plots in which it occurs) by strata. Species are grouped according to the areas in which they were found. 
Plant Species, Life-Forms, and Species Origins. A total of 104 plant taxa were collected from the Deep Creek study site. All but five of these taxa occurred within the sampling plots. Two forbs were identified as to genus only, and one grass could not be identified. Of the 101 plant species that were identified, 2 species were ferns, 26 species were grasses and sedges, 39 species were forbs and herbaceous vines, 17 species were shrubs and woody vines, and 17 species were trees. Of these 101 plant species, 93 were native to the southeastern United States (Reed 1988) and 8 were introduced. Ten of the species have annual growth forms only.

In the NAs, 53 species of plants were found within the plots, while 74 species were found within plots in the ROW. Seven introduced species occurred in plots in the ROW, one of which occurred in plots in the NAs. An eighth introduced species occurred in the ROW, but not within sampling plots. The two leading dominant species in the ROW were introduced species. All of the 10 species that are annuals occurred in the ROW, but only one species occurred in the NAs. Out of the 10 species of annuals, three are introduced. Thus, the ROW plots contained 59 species of native perennials, while the NA plots contained 51 species of native perennials.

Species Richness and Wetland Indicator Categories. Table 1 lists the number of plant species found in the two NAs combined and the two sides of the ROW combined. Numbers of species are listed by wetland indicator category for each vegetative stratum. Although the same species may occur in more than one stratum, such species are counted only once when strata are combined. Definitions of strata are provided in Section 3.3 of this report.

Table 1 lists the total number of species found in each of the two habitats (columns 3 and 4), as well as the number of species found in both areas (column 5). The number of species that occurred in one area but not in the other is also listed (columns 6 and 7). Of the 99 species occurring in sampling plots, only $28 \%$ of the species occurred in plots in both the NAs and the ROW, while an additional $25 \%$ were unique to the NAs, and $46 \%$ were unique to the ROW. Of the 25 species unique to the NAs, $64 \%$ occurred in the herb stratum. All species unique to the ROW occurred in the herb stratum.

The only UPL species was the sapling Dahoon holly (Ilex cassine), which occurred in both NAs. Ten species in the herb stratum were FACU, with nine of these species occurring in the ROW, four occurring in the NAs, and three occurring in both. Of the 99 species occurring within the site, $64 \%$ were OBL or FACW, while $3 \%$ were not identified. Figure 6 shows a comparison of the NAs and the ROW on the basis of species in each wetland category. Figure 7 shows a comparison of the NAs with the ROW in terms of percent of species within each wetland category.

Table 2 summarizes the distribution of plants in the plots on the north and south sides of the ROW. Out of a total of 74 species, $51 \%$ occurred on both sides of the ROW, an additional $26 \%$ were unique to the north side of the ROW, and $23 \%$ were unique to the south side of the ROW. Of the 74 species found in the ROW, $68 \%$ were either OBL or FACW species. A total of 73 species was found in the herb stratum only, and one species was found in the shrub stratum only. 
TABLE 1 Number of Plant Species by Wetland Indicator Category Found in the Study Plots in the NAs and the ROW (by individual stratum and combined strata) at the Deep Creek Site

\begin{tabular}{|c|c|c|c|c|c|c|c|}
\hline \multirow[b]{2}{*}{ Stratum } & \multirow[b]{2}{*}{$\begin{array}{l}\text { Wetland } \\
\text { Indicator } \\
\text { Category }\end{array}$} & \multicolumn{6}{|c|}{ Number of Species } \\
\hline & & $\begin{array}{c}\text { Occurring } \\
\text { in } \\
\text { NAs }\end{array}$ & $\begin{array}{c}\text { Occurring } \\
\text { in } \\
\text { ROW }\end{array}$ & $\begin{array}{c}\text { Common } \\
\text { to Both } \\
\text { Areas }\end{array}$ & $\begin{array}{c}\text { Unique } \\
\text { to } \\
\text { NAs }\end{array}$ & $\begin{array}{l}\text { Unique } \\
\text { to } \\
\text { ROW }\end{array}$ & Total \\
\hline \multirow[t]{7}{*}{ Herb } & OBL & 10 & 20 & 6 & 4 & 14 & 24 \\
\hline & FACW & 11 & 29 & 6 & 5 & 23 & 34 \\
\hline & FAC & 13 & 12 & 7 & 6 & 5 & 18 \\
\hline & FACU & 4 & 9 & 3 & 1 & 6 & 10 \\
\hline & UPL & 0 & 0 & 0 & 0 & 0 & 0 \\
\hline & Unid $^{b}$ & 2 & 3 & 2 & 0 & 1 & 3 \\
\hline & Total & 40 & 73 & 24 & 16 & 49 & 89 \\
\hline \multirow[t]{7}{*}{ Shrub } & OBL & 5 & 0 & 0 & 5 & 0 & 5 \\
\hline & FACW & 5 & 1 & 1 & 4 & 0 & 5 \\
\hline & FAC & 5 & 0 & 0 & 5 & 0 & 5 \\
\hline & FACU & 0 & 0 & 0 & 0 & 0 & 0 \\
\hline & UPL & 0 & 0 & 0 & 0 & 0 & 0 \\
\hline & Unid & 0 & 0 & 0 & 0 & 0 & 0 \\
\hline & Total & 15 & 1 & 1 & 14 & 0 & 15 \\
\hline \multirow[t]{7}{*}{ Sapling } & OBL & 3 & 0 & 0 & 3 & 0 & 3 \\
\hline & FACW & 4 & 0 & 0 & 4 & 0 & 4 \\
\hline & FAC & 4 & 0 & 0 & 4 & 0 & 4 \\
\hline & FACU & 0 & 0 & 0 & 0 & 0 & 0 \\
\hline & UPL & 1 & 0 & 0 & 1 & 0 & 1 \\
\hline & Unid & 0 & 0 & 0 & 0 & 0 & 0 \\
\hline & Total & 12 & 0 & 0 & 12 & 0 & 12 \\
\hline \multirow[t]{7}{*}{ Tree } & OBL & 3 & 0 & 0 & 3 & 0 & 3 \\
\hline & FACW & 2 & 0 & 0 & 2 & 0 & 2 \\
\hline & FAC & 6 & 0 & 0 & 6 & 0 & 6 \\
\hline & FACU & 0 & 0 & 0 & 0 & 0 & 0 \\
\hline & UPL & 0 & 0 & 0 & 0 & 0 & 0 \\
\hline & Unid & 0 & 0 & 0 & 0 & 0 & 0 \\
\hline & Total & 11 & 0 & 0 & 11 & 0 & 11 \\
\hline \multirow[t]{7}{*}{ Vine } & OBL & 0 & 0 & 0 & 0 & 0 & 0 \\
\hline & FACW & 1 & 0 & 0 & 1 & 0 & 1 \\
\hline & FAC & 5 & 0 & 0 & 5 & 0 & 5 \\
\hline & FACU & 0 & 0 & 0 & 0 & 0 & 0 \\
\hline & UPL & 0 & 0 & 0 & 0 & 0 & 0 \\
\hline & Unid $^{b}$ & 0 & 0 & 0 & 0 & 0 & 0 \\
\hline & Total & 6 & 0 & 0 & 6 & 0 & 6 \\
\hline
\end{tabular}




\begin{tabular}{|c|c|c|c|c|c|c|c|}
\hline \multirow[b]{2}{*}{ Stratum } & \multirow[b]{2}{*}{$\begin{array}{l}\text { Wetland } \\
\text { Indicator } \\
\text { Categorya }\end{array}$} & \multicolumn{6}{|c|}{ Number of Species } \\
\hline & & $\begin{array}{c}\text { Occurring } \\
\text { in } \\
\text { NAs }\end{array}$ & $\begin{array}{l}\text { Occurring } \\
\text { in } \\
\text { ROW }\end{array}$ & $\begin{array}{l}\text { Common } \\
\text { to Both } \\
\text { Areas }\end{array}$ & $\begin{array}{l}\text { Unique } \\
\text { to } \\
\text { NAs }\end{array}$ & $\begin{array}{c}\text { Unique } \\
\text { to } \\
\text { ROW }\end{array}$ & Total \\
\hline \multirow[t]{7}{*}{ Combined } & OBL & 14 & 20 & 7 & 7 & 13 & 27 \\
\hline & FACW & 15 & 30 & 7 & 7 & 23 & 37 \\
\hline & FAC & 17 & 12 & 9 & 8 & 3 & 21 \\
\hline & FACU & 4 & 9 & 3 & 1 & 6 & 10 \\
\hline & UPL & 1 & 0 & 0 & 2 & 0 & 1 \\
\hline & Unid & 2 & 3 & 2 & 0 & 1 & 3 \\
\hline & Total & 53 & 74 & 28 & 25 & 46 & 99 \\
\hline
\end{tabular}

a $\mathrm{OBL}=$ obligate wetland; $\mathrm{FACW}=$ facultative wetland; $F A C=$ facultative; $F A C U=$ facultative upland; UPL = obligate upland; see Appendix $B$ for more detailed information on wetland indicator categories.

b Unid = plants that could not be identified to species .

A total of 53 species occurred in plots in the NAs (Table 3); $51 \%$ of these species occurred in both NAs, while an additional $25 \%$ were unique to each NA. Six of the tree and sapling species occurred in the herb stratum as seedlings; four of these six species occurred in the herb, shrub, sapling, and tree strata. The herb strata in the two NAs were quite different from each other, with only 12 of 40 species in common, while the shrub stratum had eight of 15 species in common, the sapling stratum had eight of 12 species in common, the tree stratum had seven of 11 species in common, and five of the six species of vines occurred in both NAs. There were no conspicuous differences in distribution within wetland indicator categories between the NNA and the SNA.

Dominance. The dominant species, for the ROW and for each stratum in the NAs, along with their relative percent areal cover (RPCs), are listed in Table 4. Areal covers for each species in each habitat and stratum, averaged over five plots per habitat, are given in Table C.3. All dominant species were obligate (OBL), facultative wetland (FACW), or facultative (FAC), except Bahia grass (Paspalum notatum), which is an introduced facultative upland (FACU+) species. Dominance for woody vines was not determined because areal cover data were not collected for vines. The two most abundant vines, muscadine grape (Vitis rotundifolia) and yellow jessamine (Gelsemium sempervirens), are both FAC species, as were all other vines except southeast decumaria (Decumaria barbara), which is a FACW species.

Only a sparse herb stratum occurred in the NAs. The sum of areal cover for all species making up the herb stratum in the NAs was $24.2 \%$. The average areal covers of the dominant species, slender spikegrass (Chasmanthium laxum) and giant cane (Arundinaria gigantia), were 


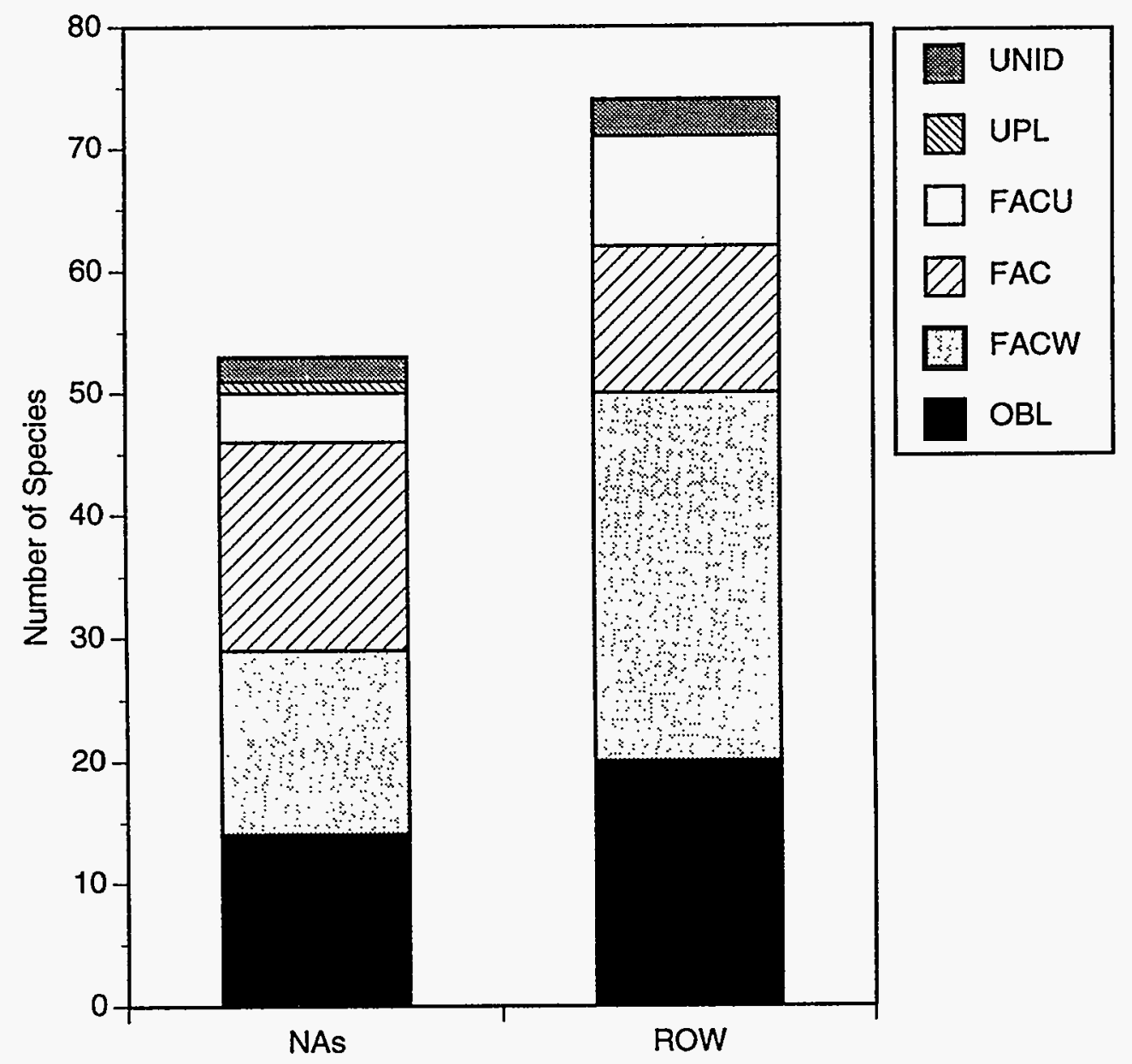

FIGURE 6 Number of Species in Each Wetland Indicator Category by Area for the Deep Creek Site

$11.4 \%$ and $3.1 \%$, respectively. In the ROW, the sum of individual species areal cover was 131.5\%; the leading dominant species, shade mudflower (Micranthemum umbrosum), had an average cover of $24.2 \%$. The two leading dominants in the ROW, shade mudflower and Bahia grass, are both introduced species. Bahia grass was the only introduced species found to occur in NAs. Individual covers of other dominant species are listed in Table 1.

In both of the NAs, American hornbeam (Carpinus caroliniana) was the only dominant species in the shrub stratum. In the combined NAs, it had an average areal cover of $27.7 \%$; for comparison, the total average areal cover for all species of shrubs in both of the NAs was $34.6 \%$. Seven species of shrubs collectively constituted the remaining $20 \%$ of the relative percent cover (RPC) for shrubs, with the next most abundant shrub having an RPC of 5\%. Thus, American hornbeam was the only shrub to make a substantial contribution to the natural vegetation. The only shrub in the ROW was a resprouting stump of green ash (Fraxinus pennsylvanica). It had an average areal cover of $0.3 \%$, but because no other shrubs were present, its RPC was a somewhat deceptive $100 \%$. 


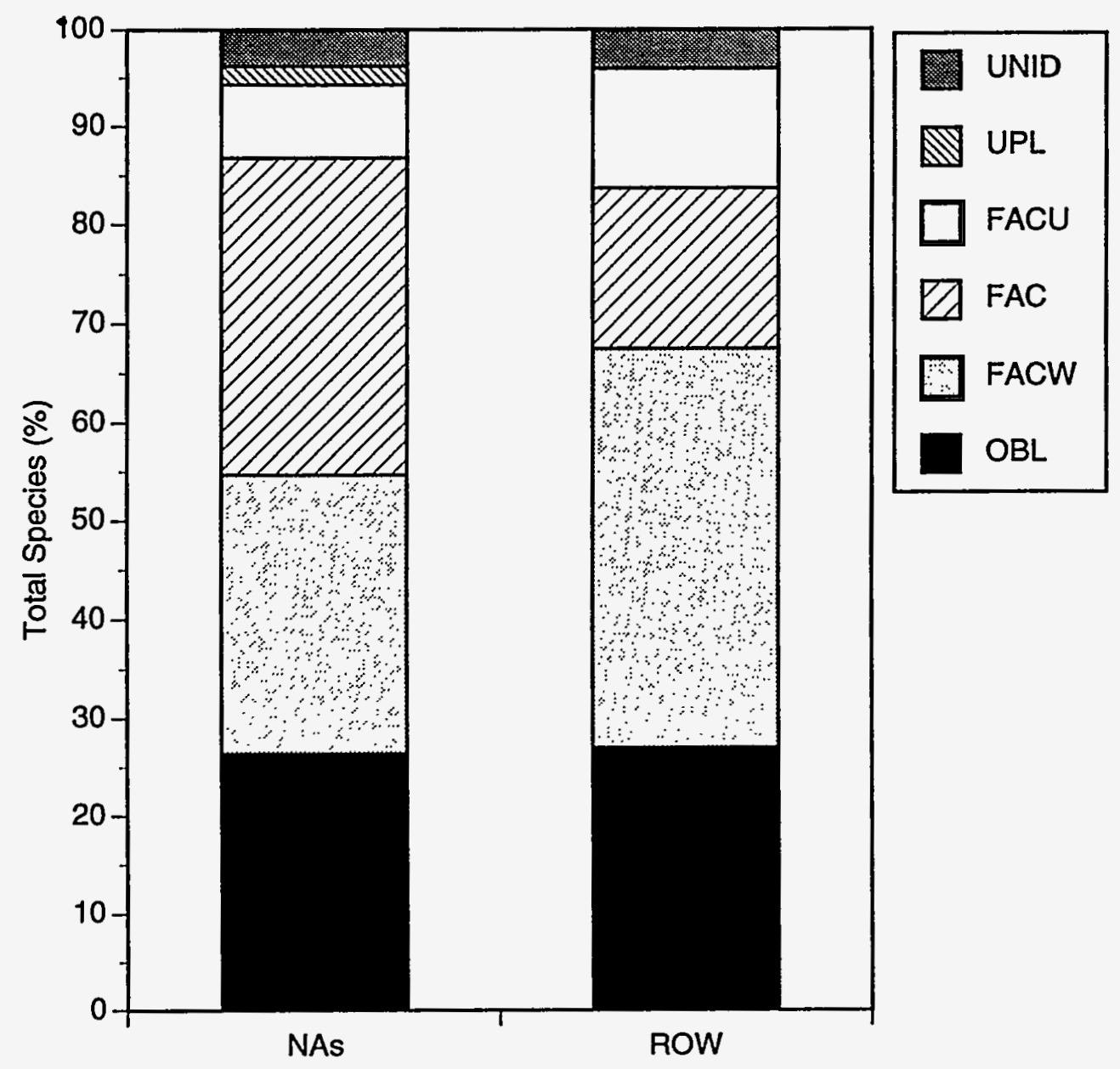

FIGURE 7 Percent of Species in Each Wetland Indicator Category by Area for the Deep Creek Site

Saplings occurred only in the NAs. Again, American hormbeam was the most prevalent dominant species in both NAs. The average areal cover of American hornbeam was $18.5 \%$, which is $69 \%$ of the sum of the areal covers of all saplings (26.8\%) for the combined NAs. No other saplings had an average areal cover of greater than $2.5 \%$, and the seven subordinate saplings collectively had a cover of $8.3 \%$.

Bald cypress (Taxodium distichum) and laurel oak (Quercus laurifolia) occurred as dominant species in each of the two NAs. Sweet gum (Liquidambar styraciflua) ranked as a dominant species in the north NA (NNA) only. When data from the two NAs were combined, bald cypress and laurel oak accounted for just over $50.9 \%$ of the total basal areas of all trees present. Nine other species of trees accounted for the remaining percentage.

Coefficient of Community Similarity. Table 5 presents Sørensen's coefficient of community values $\left(\mathrm{CC}_{\mathrm{S}}\right)$, comparing the species composition of the vegetation in the various areas. These comparisons $\left(\mathrm{CC}_{\mathrm{s}}\right)$ are based on the information in Tables 1-3. A comparison of the two 
TABLE 2 Number of Plant Species by Wetland Indicator Category Found in the Study Plots in the North and South Sides of the ROW (by individual stratum and combined strata) at the Deep Creek Site

\begin{tabular}{|c|c|c|c|c|c|c|c|}
\hline \multirow[b]{2}{*}{ Stratum } & \multirow[b]{2}{*}{$\begin{array}{l}\text { Wetland } \\
\text { Indicator } \\
\text { Category }\end{array}$} & \multicolumn{6}{|c|}{ Number of Species } \\
\hline & & $\begin{array}{l}\text { Occurring } \\
\text { in } \\
\text { North ROW }\end{array}$ & $\begin{array}{l}\text { Occurring } \\
\text { in } \\
\text { South ROW }\end{array}$ & $\begin{array}{c}\text { Common } \\
\text { to Both } \\
\text { ROWs }\end{array}$ & $\begin{array}{c}\text { Unique } \\
\text { to } \\
\text { North ROW }\end{array}$ & $\begin{array}{c}\text { Unique } \\
\text { to } \\
\text { South ROW }\end{array}$ & Total \\
\hline \multirow[t]{7}{*}{ Herb } & OBL & 15 & 14 & 9 & 6 & 5 & 20 \\
\hline & FACW & 22 & 21 & 14 & 8 & 7 & 29 \\
\hline & FAC & 9 & 8 & 5 & 4 & 3 & 12 \\
\hline & FACU & 7 & 9 & 7 & 0 & 2 & 9 \\
\hline & UPL & 0 & 0 & 0 & 0 & 0 & 0 \\
\hline & Unida $^{a}$ & 3 & 3 & 3 & 0 & 0 & 3 \\
\hline & Total & 56 & 55 & 38 & 18 & 17 & 73 \\
\hline \multirow[t]{7}{*}{ Shrub } & OBL & 0 & 0 & 0 & 0 & 0 & 0 \\
\hline & FACW & 1 & 0 & 0 & 1 & 0 & 1 \\
\hline & FAC & 0 & 0 & 0 & 0 & 0 & 0 \\
\hline & FACU & 0 & 0 & 0 & 0 & 0 & 0 \\
\hline & UPL & 0 & 0 & 0 & 0 & 0 & 0 \\
\hline & Unid & 0 & 0 & 0 & 0 & 0 & 0 \\
\hline & Total & 1 & 0 & 0 & 1 & 0 & 1 \\
\hline \multirow[t]{7}{*}{ Combined } & OBL & 15 & 14 & 9 & 6 & 5 & 20 \\
\hline & FACW & 23 & 21 & 14 & 9 & 7 & 30 \\
\hline & FAC & 9 & 8 & 5 & 4 & 3 & 12 \\
\hline & FACU & 7 & 9 & 7 & 0 & 2 & 9 \\
\hline & UPL & 0 & 0 & 0 & 0 & 0 & 0 \\
\hline & Unid & 3 & 3 & 3 & 0 & 0 & 3 \\
\hline & Total & 57 & 55 & 38 & 19 & 17 & 74 \\
\hline
\end{tabular}

a Unid = plants that could not be identified to species.

NAs results in a relatively high $\mathrm{CC}_{\mathrm{s}}$ for all strata, except the herb stratum. The two sides of the ROW also reflect a relatively high similarity $\left(\mathrm{CC}_{\mathrm{s}}=0.68\right)$. However, the low $\mathrm{CC}_{\mathrm{s}}, 0.42$, for the herb stratum of the ROW (compared with that of the herb stratum of the NAs) indicates that the complex of plants in the NAs is quite different from that in the deforested ROW. When all strata are considered, the combined NAs have low similarity $\left(\mathrm{CC}_{\mathrm{s}}=0.44\right)$, compared with the combined ROW. Sapling, tree, and vine strata are absent from the ROW, and the NAs and the ROW have less than $50 \%$ of their herb species in common. However, the $\mathrm{CC}_{\mathrm{s}}$ comparing all plants present is slightly higher than the $\mathrm{CC}_{s}$ comparing herb strata only. Some woody species occur as seedlings in the ROW. 
TABLE 3 Number of Plant Species by Wetland Indicator Category Found in the NNA and SNA (by Individual Stratum and Combined Strata) at the Deep Creek Site

\begin{tabular}{|c|c|c|c|c|c|c|c|}
\hline \multirow[b]{2}{*}{ Stratum } & \multirow[b]{2}{*}{$\begin{array}{l}\text { Wetland } \\
\text { Indicator } \\
\text { Category }\end{array}$} & \multicolumn{6}{|c|}{ Number of Species } \\
\hline & & $\begin{array}{c}\text { Occurring } \\
\text { in } \\
\text { NNA }\end{array}$ & $\begin{array}{c}\text { Occurring } \\
\text { in } \\
\text { SNA }\end{array}$ & $\begin{array}{c}\text { Common } \\
\text { to Both } \\
\text { NAs }\end{array}$ & $\begin{array}{c}\text { Unique } \\
\text { to } \\
\text { NNA }\end{array}$ & $\begin{array}{c}\text { Unique } \\
\text { to } \\
\text { SNA }\end{array}$ & Total \\
\hline \multirow[t]{7}{*}{ Herb } & OBL & 8 & 3 & 1 & 7 & 2 & 10 \\
\hline & FACW & 8 & 8 & 5 & 3 & 3 & 11 \\
\hline & FAC & 8 & 10 & 5 & 3 & 5 & 13 \\
\hline & FACU & 2 & 3 & 1 & 1 & 2 & 4 \\
\hline & UPL & 0 & 0 & 0 & 0 & 0 & 0 \\
\hline & Unida & 1 & 1 & 0 & 1 & 1 & 2 \\
\hline & Total & 27 & 25 & 12 & 15 & 13 & 40 \\
\hline \multirow[t]{7}{*}{ Shrub } & OBL & 4 & 3 & 2 & 2 & 1 & 5 \\
\hline & FACW & 3 & 5 & 2 & 0 & 2 & 5 \\
\hline & FAC & 3 & 5 & 4 & 0 & 2 & 5 \\
\hline & FACU & 0 & 0 & 0 & 0 & 0 & 0 \\
\hline & UPL & 0 & 0 & 0 & 0 & 0 & 0 \\
\hline & Unid & 0 & 0 & 0 & 0 & 0 & 0 \\
\hline & Total & 10 & 13 & 8 & 2 & 5 & 15 \\
\hline \multirow[t]{7}{*}{ Sapling } & $\mathrm{OBL}$ & 2 & 3 & 2 & 0 & 1 & 3 \\
\hline & FACW & 3 & 3 & 2 & 1 & 1 & 4 \\
\hline & FAC & 4 & 3 & 3 & 1 & 0 & 4 \\
\hline & FACU & 0 & 0 & 0 & 0 & 0 & 0 \\
\hline & UPL & 1 & 1 & 1 & 0 & 0 & 1 \\
\hline & Unid & 0 & 0 & 0 & 0 & 0 & 0 \\
\hline & Total & 10 & 10 & 8 & 2 & 2 & 12 \\
\hline \multirow[t]{7}{*}{ Tree } & OBL & 3 & 3 & 3 & 0 & 0 & 3 \\
\hline & FACW & 2 & 1 & 1 & 1 & 0 & 2 \\
\hline & FAC & 3 & 6 & 3 & 0 & 3 & 6 \\
\hline & FACU & 0 & 0 & 0 & 0 & 0 & 0 \\
\hline & UPL & 0 & 0 & 0 & 0 & 0 & 0 \\
\hline & Unid & 0 & 0 & 0 & 0 & 0 & 0 \\
\hline & Total & 8 & 10 & 7 & 1 & 3 & 11 \\
\hline \multirow[t]{7}{*}{ Vine } & OBL & 0 & 0 & 0 & 0 & 0 & 0 \\
\hline & FACW & 1 & 1 & 1 & 0 & 0 & 1 \\
\hline & FAC & 4 & 5 & 4 & 0 & 1 & 5 \\
\hline & FACU & 0 & 0 & 0 & 0 & 0 & 0 \\
\hline & UPL & 0 & 0 & 0 & 0 & 0 & 0 \\
\hline & Unid & 0 & 0 & 0 & 0 & 0 & 0 \\
\hline & Total & 5 & 6 & 5 & 0 & 1 & 6 \\
\hline
\end{tabular}




\begin{tabular}{|c|c|c|c|c|c|c|c|}
\hline \multirow[b]{2}{*}{ Stratum } & \multirow[b]{2}{*}{$\begin{array}{l}\text { Wetland } \\
\text { Indicator } \\
\text { Category }\end{array}$} & \multicolumn{6}{|c|}{ Number of Species } \\
\hline & & $\begin{array}{c}\text { Occurring } \\
\text { in } \\
\text { NNA }\end{array}$ & $\begin{array}{l}\text { Occurring } \\
\text { in } \\
\text { SNA }\end{array}$ & $\begin{array}{c}\text { Common } \\
\text { to Both } \\
\text { NAs }\end{array}$ & $\begin{array}{l}\text { Unique } \\
\text { to } \\
\text { NNA }\end{array}$ & $\begin{array}{l}\text { Unique } \\
\text { to } \\
\text { SNA }\end{array}$ & Total \\
\hline \multirow[t]{7}{*}{ Combined } & OBL & 13 & 6 & 5 & 8 & 1 & 14 \\
\hline & FACW & 11 & 11 & 8 & 3 & 3 & 14 \\
\hline & FAC & 12 & 18 & 12 & 0 & 6 & 18 \\
\hline & FACU & 2 & 3 & 1 & 1 & 2 & 4 \\
\hline & UPL & 1 & 1 & 1 & 0 & 0 & 1 \\
\hline & Unid & 1 & 1 & 0 & 1 & 1 & 2 \\
\hline & Total & 40 & 40 & 27 & 13 & 13 & 53 \\
\hline
\end{tabular}

a Unid = plants that could not be identified to species.

Prevalence Index Values and Average Wetland Values. Table 6 presents both PIVs and AWVs for the combined ROW plots and the combined NA plots by stratum for all species and for dominant species only. Both AWVs and PIVs for the herb strata in the NAs and in the ROW had values close to 2.00. Because the dominant species were mostly OBL and FACW species, PIVs in both the NAs and the ROW were slightly lower than the AWVs. The single dominant species that occurred in both shrub and sapling strata in the NAs was a FAC species; as a result, both the PIVs and AVWs for the dominants in those strata were only 3.00. When all species were considered, the values were lower. When all tree species were considered, the PIVs and AWVs were slightly greater than 2.00; however, when only dominant species were considered, the values were close to 1.50 , indicating that the dominant tree species had a greater fidelity to wetlands than other tree species found there.

\subsection{Brandy Branch Study Site}

\subsubsection{General Ecology}

The Brandy Branch study site is on the floodplain of Brandy Branch Creek, which has three channels at the pipeline crossing. The southernmost channel was a drainage approximately 2-3 $\mathrm{m}$ wide and $60-90 \mathrm{~cm}$ deep. Sampling was started about $10 \mathrm{~m}$ north of this channel. The second drainage was undefined within the ROW, with several broad and shallow flows of water and various seepage channels in the poorly consolidated soils of the ROW. This seepage area occurred mostly between transects 2 and 3, overlapping transect 3 somewhat on the western side 
TABLE 4 Dominant Species by Vegetative Stratum for Each Area at the Deep Creek Site

\begin{tabular}{|c|c|c|c|c|c|c|}
\hline Stratum & Area & Scientific Name & Common Name & $\begin{array}{l}\text { Wetland } \\
\text { Indicator } \\
\text { Category }\end{array}$ & $\begin{array}{c}\text { Relative } \\
\text { Percent } \\
\text { Cover }\end{array}$ & $\begin{array}{c}\text { Sum of } \\
\text { Relative } \\
\text { Percents } \\
\text { Cover }\end{array}$ \\
\hline \multirow[t]{2}{*}{ Herb } & NAs & $\begin{array}{l}\text { Chasmanthium laxum } \\
\text { Arundinaria gigantea }\end{array}$ & $\begin{array}{l}\text { Slender spikegrass } \\
\text { Giant cane }\end{array}$ & $\begin{array}{l}\text { FACW- } \\
\text { FACW }\end{array}$ & $\begin{array}{l}46.8 \\
12.7\end{array}$ & 59.5 \\
\hline & ROW & $\begin{array}{l}\text { Micranthemum umbrosuma } \\
\text { Paspalum notatum } \\
\text { Juncus coriaceus } \\
\text { Scirpus cyperinus } \\
\text { Dichanthelium dichotomum } \\
\text { Juncus marginatus }\end{array}$ & $\begin{array}{l}\text { Shade mudflower } \\
\text { Bahia grass } \\
\text { Leathery rush } \\
\text { Wool-grass } \\
\text { Cypress witchgrass } \\
\text { Grass-leaf rush }\end{array}$ & $\begin{array}{l}\text { OBL } \\
\text { FACU+ } \\
\text { FACW } \\
\text { OBL } \\
\text { FAC } \\
\text { FACW }\end{array}$ & $\begin{array}{r}18.4 \\
8.5 \\
6.8 \\
6.2 \\
6.1 \\
5.1\end{array}$ & 51.1 \\
\hline \multirow[t]{2}{*}{ Shrub } & NAs & Carpinus caroliniana & American hornbeam & FAC & 80.1 & 80.1 \\
\hline & ROW & Fraxinus pennsylvanica & Green ash & FACW & 100 & 100 \\
\hline Sapling ${ }^{b}$ & NAs & Carpinus caroliniana & American hornbeam & FAC & 69 & 69 \\
\hline Tree $^{b}$ & NAs & $\begin{array}{l}\text { Taxodium distichum } \\
\text { Quercus laurifolia }\end{array}$ & $\begin{array}{l}\text { Bald cypress } \\
\text { Laurel oak }\end{array}$ & $\begin{array}{l}\text { OBL } \\
\text { FACW }\end{array}$ & $\begin{array}{l}25.8 \\
25.1\end{array}$ & 50.9 \\
\hline
\end{tabular}

a Introduced species.

b Not represented in the ROW. 
TABLE 5 Coefficient of Community Values Comparing Similarity of Species Occurring in Study Plots at the Deep Creek Site

\begin{tabular}{lccc}
\hline & \multicolumn{3}{c}{$\mathrm{CC}_{\mathrm{s}}$ for Given Comparison } \\
\cline { 2 - 4 } Stratum & $\begin{array}{c}\text { South ROW } \\
\text { to } \\
\text { North ROW }\end{array}$ & SNA to NNA \\
\hline Herb & 0.42 & 0.68 & 0.46 \\
Shrub & 0.13 & 0.00 & 0.70 \\
Sapling & 0.00 & 0.00 & 0.80 \\
Tree & 0.00 & 0.00 & 0.78 \\
Vine & 0.00 & 0.00 & 0.91 \\
Combined & 0.44 & 0.68 & 0.68 \\
\hline
\end{tabular}

of the ROW. Within the forested area to the west, there was little evidence of a channel; however, a shallow channel was present in the forest to the east. The third channel, the main channel of Brandy Branch Creek, was to the north of the last transect. The NAs on either side of the ROW were forested by lowland hardwoods, occasional spruce pine (Pinus glabra), and bald cypress (Taxodium distichym). No evidence of recent logging was seen within the area sampled.

Soil cores taken with a hand auger depicted a soil profile consistent with Ellabelle soils, as described in Section 2.3.

\subsubsection{Plant Community}

Field data on the vegetative communities in the ROW and in the NAs are presented in Appendix C. Table C.4 lists plants found in this site by scientific names and authorities and gives common names, wetland indicator categories, life-forms, and origin, as determined from Reed (1988). Table C.5 is a compilation of the field plot data, listing the percent areal cover for each species occurring within each sample plot. Table C.6 summarizes the distribution of each species by average percent areal cover and frequency. Species are grouped according to the areas in which they were found. 
TABLE 6 Prevalence Index and Average Wetland Values for all Species and Dominant Species Found in the NAs and the ROW (by individual stratum and combined strata) at the Deep Creek Site

\begin{tabular}{|c|c|c|c|c|}
\hline Stratum & Area & $\begin{array}{l}\text { Species } \\
\text { Category }\end{array}$ & $\begin{array}{l}\text { Prevalence } \\
\text { Index Value }\end{array}$ & $\begin{array}{c}\text { Average } \\
\text { Wetland Value }\end{array}$ \\
\hline Herb & NAs & $\begin{array}{l}\text { All species } \\
\text { Dominants }\end{array}$ & $\begin{array}{l}2.09 \\
2.00\end{array}$ & $\begin{array}{l}2.29 \\
2.00\end{array}$ \\
\hline & ROW & $\begin{array}{l}\text { All species } \\
\text { Dominants }\end{array}$ & $\begin{array}{l}2.06 \\
1.97\end{array}$ & $\begin{array}{l}2.14 \\
2.17\end{array}$ \\
\hline Shrub & NAs & $\begin{array}{l}\text { All species } \\
\text { Dominants }\end{array}$ & $\begin{array}{l}2.83 \\
3.00\end{array}$ & $\begin{array}{l}2.00 \\
3.00\end{array}$ \\
\hline & ROW & $\begin{array}{l}\text { All species } \\
\text { Dominants }\end{array}$ & $\begin{array}{l}2.00 \\
2.00\end{array}$ & $\begin{array}{l}2.00 \\
2.00\end{array}$ \\
\hline Sapling & NAs & $\begin{array}{l}\text { All species } \\
\text { Dominants }\end{array}$ & $\begin{array}{l}2.73 \\
3.00\end{array}$ & $\begin{array}{l}2.33 \\
3.00\end{array}$ \\
\hline Tree & NAs & $\begin{array}{l}\text { All species } \\
\text { Dominants }\end{array}$ & $\begin{array}{l}2.01 \\
1.49\end{array}$ & $\begin{array}{l}2.27 \\
1.50\end{array}$ \\
\hline Combined & $\begin{array}{l}\text { NAs } \\
\text { ROW }\end{array}$ & $\begin{array}{l}\text { All species } \\
\text { Dominants }\end{array}$ & $\begin{array}{l}\mathrm{NC}^{\mathrm{a}} \\
\mathrm{NC}\end{array}$ & $\begin{array}{l}2.27 \\
2.14\end{array}$ \\
\hline
\end{tabular}

a Values could not be calculated because cover values are not additive.

Plant Life-Forms and Species Origins. A total of 90 taxa of plants was collected from the Brandy Branch study site. Twelve of these species did not occur within the sampling plots. One forb could be identified to genus only. The 89 taxa identified to species consisted of 2 ferns, 25 grasses and sedges, 32 forbs and herbaceous vines, 13 shrubs and woody vines, and 17 tree species. Eighty-three of these species are native to the southeastern United States (Reed 1988), and six species are introduced. Seven of the species occur only as annuals.

A total of 56 species of plants occurred within plots in the NAs, while 38 species were found within plots in the ROW. Three of the six introduced species occurred in both the ROW and the NAs, one species occurred only in the NAs, and two species were limited to the ROW. Of the seven species with annual growth forms only, all occurred in the ROW, and four species were limited to the ROW. Only one of the annuals is an introduced species. Thus, the ROW plots contained 26 native perennial species (and one plant identified to genus only). The NA plots contained 49 native perennial species. 
Species Richness and Wetland Indicator Categories. Table 7 lists the number of plant species by wetland indicator category, for each vegetative stratum, found in the two NAs combined and in the two sides of the ROW combined. Columns 3 and 4 of Table 7 list the total number of species found in each of the two types of habitat, while column 5 lists the number of species found in both habitats. Columns 6 and 7 list the number of species that occurred in one habitat but not in the other. Of the 78 species occurring in sampling plots, only $21 \%$ occurred in plots in both the NAs and the ROW; an additional $51 \%$ were unique to the NAs, and an additional $28 \%$ were unique to the ROW. Of the 40 species unique to the NAs, $75 \%$ occurred in the herb stratum. All species unique to the ROW occurred in the herb stratum.

Seven species in the herb stratum were FACU. Two of these species occurred in the ROW, and six species occurred in the NAs; one species occurred in both. Of the 78 species found within this site, $72 \%$ were OBL or FACW (one species was not identified). Figure 8 shows a comparison, on the basis of wetland indicator categories, of the total number of species found in the NAs with those found in the ROW. Figure 9 shows a similar comparison in terms of percent of species within each wetland indicator category.

Table 8 summarizes the distribution of plants in the plots on the north and south sides of the ROW. Of the 38 species occurring in the ROW, $37 \%$ occurred on both sides; an additional $53 \%$ were unique to the east side, and $11 \%$ were unique to the west side. Of the 38 species found in the ROW, 79\% were either OBL or FACW species.

A total of 56 species occurred in plots in the NAs (Table 9). Of these species, 55\% occurred in both NAs, while $32 \%$ additional species were unique to the east natural area (ENA) and $13 \%$ to the west natural area (WNA). Seven of the tree and sapling species occurred in the herb stratum as seedlings; $57 \%$ of these species occurred in the herb, shrub, sapling, and tree strata. The herb stratum was quite different in the two NAs - $41 \%$ of 46 species occurred in both NAs, while the shrub stratum had $80 \%$ of 15 species in common, the sapling stratum had $64 \%$ of 11 species in common, the tree stratum had $82 \%$ of 11 species in common, and both species of vines occurred in both NAs. Distributions within wetland indicator categories between the ENA and the WNA were similar.

Dominance. The dominant species by stratum and their RPCs are listed in Table 10. Average cover, based on five plots per area, is given in Table C.6 for each species by stratum in each area. All dominants were OBL, FACW, or FAC species. The only two species of vines occurring in the plots were southeast decumaria (Decumaria barbara), which is FACW, and poison ivy (Toxicodendron radicans), which is FAC. Both species averaged 1.2 vines per plot.

The herb stratum in the NAs was sparse; the sum of the average areal covers for all species in both areas combined was $43 \%$. The two dominant species, shade mudflower and loose-flower water-willow (Justicia ovata), had average areal covers of $13.6 \%$ and $10.9 \%$, respectively. In the ROW, the sum of average areal covers for individual species in the herb stratum was $103 \%$. The 
TABLE 7 Number of Plant Species by Wetland Indicator Category Found in the Study Plots in the NAs and the ROW (by individual stratum and combined strata) at the Brandy Branch Site

\begin{tabular}{|c|c|c|c|c|c|c|c|}
\hline \multirow[b]{2}{*}{ Stratum } & \multirow[b]{2}{*}{$\begin{array}{l}\text { Wetland } \\
\text { Indicator } \\
\text { Category }\end{array}$} & \multicolumn{6}{|c|}{ Number of Species } \\
\hline & & $\begin{array}{c}\text { Occurring } \\
\text { in } \\
\text { NAs }\end{array}$ & $\begin{array}{c}\text { Occurring } \\
\text { in } \\
\text { ROW }\end{array}$ & $\begin{array}{l}\text { Common } \\
\text { to Both } \\
\text { Areas }\end{array}$ & $\begin{array}{l}\text { Unique } \\
\text { to } \\
\text { NAs }\end{array}$ & $\begin{array}{l}\text { Unique } \\
\text { to } \\
\text { Row }\end{array}$ & Total \\
\hline \multirow[t]{7}{*}{ Herb } & OBL & 12 & 19 & 6 & 6 & 13 & 25 \\
\hline & FACW & 17 & 11 & 6 & 11 & 5 & 22 \\
\hline & FAC & 11 & 5 & 3 & 8 & 2 & 13 \\
\hline & FACU & 6 & 2 & 1 & 5 & 1 & 7 \\
\hline & UPL & 0 & 0 & 0 & 0 & 0 & 0 \\
\hline & Unida & 0 & 1 & 0 & 0 & 1 & 1 \\
\hline & Total & 46 & 38 & 16 & 30 & 22 & 68 \\
\hline \multirow[t]{7}{*}{ Shrub } & OBL & 7 & 0 & 0 & 7 & 0 & 7 \\
\hline & FACW & 6 & 0 & 0 & 6 & 0 & 6 \\
\hline & FAC & 0 & 0 & 0 & 0 & 0 & 0 \\
\hline & FACU & 0 & 0 & 0 & 0 & 0 & 0 \\
\hline & UPL & 0 & 0 & 0 & 0 & 0 & 0 \\
\hline & Unid & 15 & 0 & 0 & 15 & 0 & 15 \\
\hline & Total & & & & & & \\
\hline \multirow[t]{7}{*}{ Sapling } & OBL & 1 & 0 & 0 & 2 & 0 & 2 \\
\hline & FACW & 6 & 0 & 0 & 5 & 0 & 5 \\
\hline & FAC & 4 & 0 & 0 & 4 & 0 & 4 \\
\hline & FACU & 0 & 0 & 0 & 0 & 0 & 0 \\
\hline & UPL & 0 & 0 & 0 & 0 & 0 & 0 \\
\hline & Unid & 0 & 0 & 0 & 0 & 0 & 0 \\
\hline & Total & 11 & 0 & 0 & 11 & 0 & 11 \\
\hline \multirow[t]{7}{*}{ Tree } & OBL & 3 & 0 & 0 & 3 & 0 & 3 \\
\hline & FACW & 6 & 0 & 0 & 6 & 0 & 6 \\
\hline & FAC & 2 & 0 & 0 & 2 & 0 & 2 \\
\hline & FACU & 0 & 0 & 0 & 0 & 0 & 0 \\
\hline & UPL & 0 & 0 & 0 & 0 & 0 & 0 \\
\hline & Unid & 0 & 0 & 0 & 0 & 0 & 0 \\
\hline & Total & 11 & 0 & 0 & 11 & 0 & 11 \\
\hline \multirow[t]{7}{*}{ Vine } & OBL & 0 & 0 & 0 & 0 & 0 & 0 \\
\hline & FACW & 1 & 0 & 0 & 1 & 0 & 1 \\
\hline & FAC & 1 & 0 & 0 & 1 & 0 & 1 \\
\hline & FACU & 0 & 0 & 0 & 0 & 0 & 0 \\
\hline & UPL & 0 & 0 & 0 & 0 & 0 & 0 \\
\hline & Unid & 0 & 0 & 0 & 0 & 0 & 0 \\
\hline & Total & 2 & 0 & 0 & 2 & 0 & 2 \\
\hline
\end{tabular}


TABLE 7 (Cont.)

\begin{tabular}{|c|c|c|c|c|c|c|c|}
\hline \multirow[b]{2}{*}{ Stratum } & \multirow[b]{2}{*}{$\begin{array}{l}\text { Wetland } \\
\text { Indicator } \\
\text { Category }\end{array}$} & \multicolumn{6}{|c|}{ Number of Species } \\
\hline & & $\begin{array}{c}\text { Occurring } \\
\text { in } \\
\text { NAs }\end{array}$ & $\begin{array}{c}\text { Occurring } \\
\text { in } \\
\text { ROW }\end{array}$ & $\begin{array}{c}\text { Common } \\
\text { to Both } \\
\text { Areas }\end{array}$ & $\begin{array}{l}\text { Unique } \\
\text { to } \\
\text { NAs }\end{array}$ & $\begin{array}{c}\text { Unique } \\
\text { to } \\
\text { Row }\end{array}$ & Total \\
\hline \multirow[t]{7}{*}{ Combined } & OBL & 15 & 19 & 6 & 9 & 13 & 28 \\
\hline & FACW & 23 & 11 & 6 & 17 & 5 & 28 \\
\hline & FAC & 12 & 5 & 3 & 9 & 2 & 14 \\
\hline & FACU & 6 & 2 & 1 & 5 & 1 & 7 \\
\hline & UPL & 0 & 0 & 0 & 0 & 0 & 0 \\
\hline & Unid & 0 & 1 & 0 & 0 & 1 & 1 \\
\hline & Total & 56 & 38 & 16 & 40 & 22 & 78 \\
\hline
\end{tabular}

a Unid = plants that could not be identified to species.

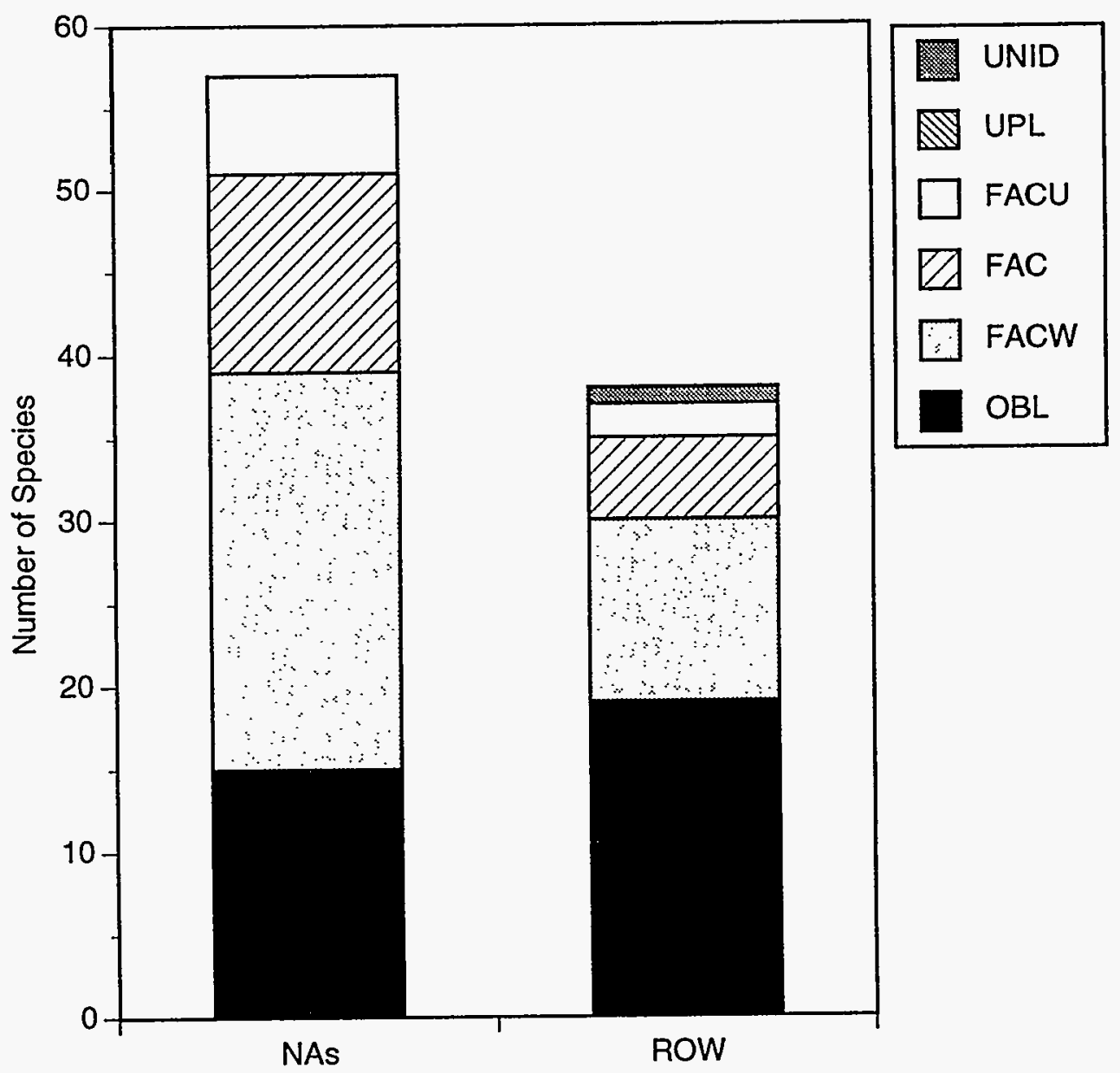

FIGURE 8 Number of Species in Each Wetland Indicator Category by Area for the Brandy Branch Site 


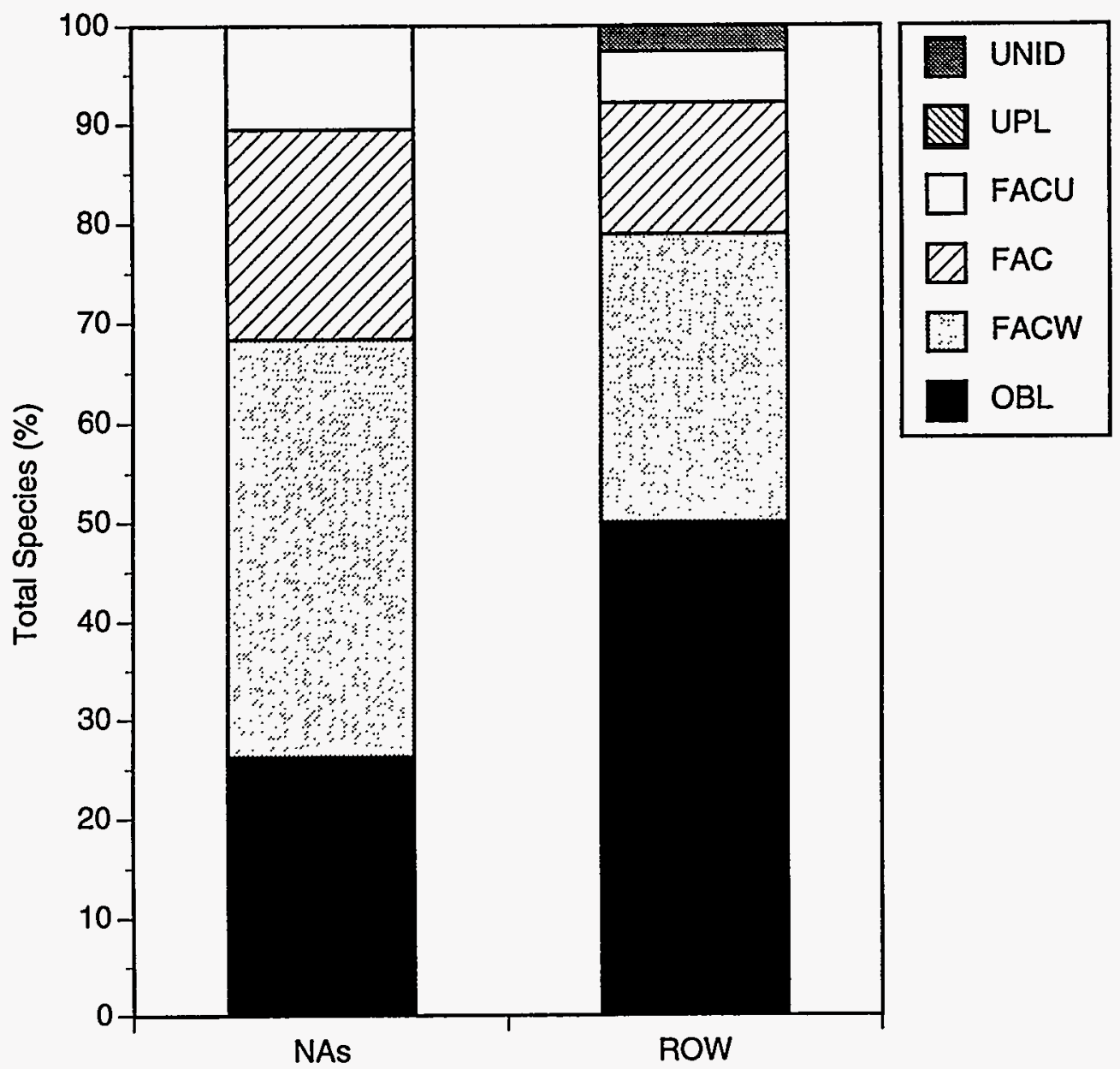

FIGURE 9 Percent of Species in Each Wetland Indicator Category by Area for the Brandy Branch Site

leading dominant, shade mudflower, had an average cover of 49.5\%; the other dominant, creeping seedbox (Ludwegia repens), had an average areal cover of 19.1\%. Individual cover of other dominant species can be found in Table 7.

The shrub stratum in the NAs was dominated by American hornbeam and green ash (Fraxinus pennsylvanica); average areal covers for these species were $7.5 \%$ and $2.2 \%$, respectively. Average covers for the 14 other shrub species summed to $6.4 \%$, and only Carolina ash (Fraxinus caroliniana) had a cover greater than $1 \%$.

The sapling stratum in the NAs was dominated by green ash and sweetbay magnolia (Magnolia virginiana); the covers of these species were $4.7 \%$ and $1.5 \%$, respectively, out of a composite cover of $10.5 \%$ for all sapling species present. Nine species of saplings made up the other $4.3 \%$ of the total areal cover of the sapling stratum; none of these nine had an average areal cover greater than $1 \%$. 
TABLE 8 Number of Plant Species by Wetland Indicator Category Found in the Study Plots in the West and East Sides of the ROW (by individual stratum and combined strata) at the Brandy Branch Site

\begin{tabular}{|c|c|c|c|c|c|c|c|}
\hline \multirow[b]{2}{*}{ Stratum } & \multirow[b]{2}{*}{$\begin{array}{l}\text { Wetland } \\
\text { Indicator } \\
\text { Category }\end{array}$} & \multicolumn{6}{|c|}{ Number of Species } \\
\hline & & $\begin{array}{l}\text { Occurring } \\
\text { in } \\
\text { West ROW }\end{array}$ & $\begin{array}{l}\text { Occurring } \\
\text { in } \\
\text { East Row }\end{array}$ & $\begin{array}{c}\text { Common } \\
\text { to Both } \\
\text { ROWs }\end{array}$ & $\begin{array}{c}\text { Unique } \\
\text { to } \\
\text { West ROW }\end{array}$ & $\begin{array}{c}\text { Unique } \\
\text { to } \\
\text { East Row }\end{array}$ & Total \\
\hline \multirow[t]{7}{*}{ Herb } & OBL & 9 & 17 & 7 & 2 & 10 & 19 \\
\hline & FACW & 7 & 10 & 6 & 1 & 4 & 11 \\
\hline & FAC & 1 & 4 & 0 & 1 & 4 & 5 \\
\hline & FACU & 1 & 2 & 1 & 0 & 1 & 2 \\
\hline & UPL & 0 & 0 & 0 & 0 & 0 & 0 \\
\hline & Unida & 0 & 1 & 0 & 0 & 1 & 1 \\
\hline & Total & 18 & 34 & 14 & 4 & 20 & 38 \\
\hline \multirow[t]{7}{*}{ Combined } & OBL & 9 & 17 & 7 & 2 & 10 & 19 \\
\hline & FACW & 7 & 10 & 6 & 1 & 4 & 11 \\
\hline & FAC & 1 & 4 & 0 & 1 & 4 & 5 \\
\hline & FACU & 1 & 2 & 1 & 0 & 1 & 2 \\
\hline & UPL & 0 & 0 & 0 & 0 & 0 & 0 \\
\hline & Unid & 0 & 1 & 0 & 0 & 1 & 1 \\
\hline & Total & 18 & 34 & 14 & 4 & 20 & 38 \\
\hline
\end{tabular}

a Unid = plants that could not be identified to species.

Three tree species - laurel oak, sweet gum, and red maple (Acer rubrum) - ranked as dominant species in the NAs. These three species, with respective basal areas of $12.09,10.31$, and $8.52 \mathrm{~m}^{2} / \mathrm{ha}$, accounted for $63.6 \%$ of the total basal area of all trees present. Eight other species of trees accounted for the rest. Ogeechee tupelo (Nyssa ogeche), with a basal area of $5.73 \mathrm{~m}^{2} / \mathrm{ha}$, was the only other species with a basal area greater than $3.50 \mathrm{~m}^{2} / \mathrm{ha}$. The total basal area $\left(48.63 \mathrm{~m}^{2} / \mathrm{ha}\right)$ for all trees at this site was almost double that for all trees at the Deep Creek site $\left(24.69 \mathrm{~m}^{2} / \mathrm{ha}\right)$.

Coefficient of Community Similarity. Table 11 presents $\mathrm{CC}_{\mathrm{s}}$ values, derived by comparing the species composition of the vegetation in the various areas. (These comparisons are based on the information in Tables 7-9.) A comparison of the two NAs yields relatively high $\mathrm{CC}_{\mathrm{s}}$ values for all strata, except the herb stratum, which had a $\mathrm{CC}_{\mathrm{s}}$ of 0.58 . The two sides of the ROW had a $\mathrm{CC}_{\mathrm{S}}$ of 0.54 . The combined NAs showed little similarity $\left(\mathrm{CC}_{\mathrm{s}}=0.34\right)$ to the ROW because of the absence of sapling, tree, and vine strata on the ROW and because the areas had less than $50 \%$ of their herb species in common. The $\mathrm{CC}_{\mathrm{s}}(0.38)$ comparing the herb stratum of the ROW with the herb stratum of the forested NAs indicates a substantially different complex of plants in the deforested ROW. 
TABLE 9 Number of Plant Species by Wetland Indicator Category Found in the Study Plots in the WNA and ENA (by individual stratum and combined strata) at the Brandy Branch Site

\begin{tabular}{|c|c|c|c|c|c|c|c|}
\hline \multirow[b]{2}{*}{ Stratum } & \multirow[b]{2}{*}{$\begin{array}{l}\text { Wetland } \\
\text { Indicator } \\
\text { Category }\end{array}$} & \multicolumn{6}{|c|}{ Number of Species } \\
\hline & & $\begin{array}{c}\text { Occurring } \\
\text { in } \\
\text { WNA }\end{array}$ & $\begin{array}{c}\text { Occurring } \\
\text { in } \\
\text { ENA }\end{array}$ & $\begin{array}{c}\text { Common } \\
\text { to Both } \\
\text { NAs }\end{array}$ & $\begin{array}{c}\text { Unique } \\
\text { to } \\
\text { WNA }\end{array}$ & $\begin{array}{c}\text { Unique } \\
\text { to } \\
\text { ENA }\end{array}$ & Total \\
\hline \multirow[t]{7}{*}{ Herb } & OBL & 6 & 10 & 4 & 2 & 6 & 12 \\
\hline & FACW & 12 & 13 & 8 & 4 & 5 & 17 \\
\hline & FAC & 8 & 9 & 6 & 2 & 3 & 11 \\
\hline & FACU & 3 & 4 & 1 & 2 & 3 & 6 \\
\hline & UPL & 0 & 0 & 0 & 0 & 0 & 0 \\
\hline & Unida & 0 & 0 & 0 & 0 & 0 & 0 \\
\hline & Total & 29 & 36 & 19 & 10 & 17 & 46 \\
\hline \multirow[t]{7}{*}{ Shrub } & OBL & 2 & 2 & 2 & 0 & 0 & 2 \\
\hline & FACW & $\overline{6}$ & $\overline{6}$ & 5 & 1 & 1 & 7 \\
\hline & FAC & 5 & 6 & 5 & 0 & 1 & 6 \\
\hline & FACU & 0 & 0 & 0 & 0 & 0 & 0 \\
\hline & UPL & 0 & 0 & 0 & 0 & 0 & 0 \\
\hline & Unid & 0 & 0 & 0 & 0 & 0 & 0 \\
\hline & Total & 13 & 14 & 12 & 1 & 2 & 15 \\
\hline \multirow[t]{7}{*}{ Sapling } & OBL & 1 & 2 & 1 & 0 & 1 & 2 \\
\hline & FACW & 4 & 4 & 3 & 1 & 1 & 5 \\
\hline & FAC & 4 & 3 & 3 & 1 & 0 & 4 \\
\hline & FACU & 0 & 0 & 0 & 0 & 0 & 0 \\
\hline & UPL & 0 & 0 & 0 & 0 & 0 & 0 \\
\hline & Unid & 0 & 0 & 0 & 0 & 0 & 0 \\
\hline & Total & 9 & 9 & 7 & 2 & 2 & 11 \\
\hline \multirow[t]{7}{*}{ Tree } & $\mathrm{OBL}$ & 2 & 3 & 2 & 0 & 1 & 3 \\
\hline & FACW & 5 & 6 & 5 & 0 & 1 & 6 \\
\hline & FAC & 2 & 2 & 2 & 0 & 0 & 2 \\
\hline & FACU & 0 & 0 & 0 & 0 & 0 & 0 \\
\hline & UPL & 0 & 0 & 0 & 0 & 0 & 0 \\
\hline & Unid & 0 & 0 & 0 & 0 & 0 & 0 \\
\hline & Total & 9 & 11 & 9 & 0 & 2 & 11 \\
\hline \multirow[t]{7}{*}{ Vine } & OBL & 0 & 0 & 0 & 0 & 0 & 0 \\
\hline & FACW & 1 & 1 & 1 & 0 & 0 & 1 \\
\hline & FAC & 1 & 1 & 1 & 0 & 0 & 1 \\
\hline & FACU & 0 & 0 & 0 & 0 & 0 & 0 \\
\hline & UPL & 0 & 0 & 0 & 0 & 0 & 0 \\
\hline & Unid & 0 & 0 & 0 & 0 & 0 & 0 \\
\hline & Total & 2 & 2 & 2 & 0 & 0 & 2 \\
\hline
\end{tabular}


TABLE 9 (Cont.)

\begin{tabular}{|c|c|c|c|c|c|c|c|}
\hline \multirow[b]{2}{*}{ Stratum } & \multirow[b]{2}{*}{$\begin{array}{l}\text { Wetland } \\
\text { Indicator } \\
\text { Category }\end{array}$} & \multicolumn{6}{|c|}{ Number of Species } \\
\hline & & $\begin{array}{c}\text { Occurring } \\
\text { in } \\
\text { WNA }\end{array}$ & $\begin{array}{c}\text { Occurring } \\
\text { in } \\
\text { ENA }\end{array}$ & $\begin{array}{l}\text { Common } \\
\text { to Both } \\
\text { NAs }\end{array}$ & $\begin{array}{c}\text { Unique } \\
\text { to } \\
\text { WNA }\end{array}$ & $\begin{array}{c}\text { Unique } \\
\text { to } \\
\text { ENA }\end{array}$ & Total \\
\hline \multirow[t]{7}{*}{ Combined } & OBL & 8 & 13 & 6 & 2 & 7 & 15 \\
\hline & FACW & 18 & 21 & 16 & 2 & 5 & 23 \\
\hline & FAC & 9 & 11 & 8 & 1 & 3 & 12 \\
\hline & FACU & 3 & -4 & 1 & 2 & 3 & 6 \\
\hline & UPL & 0 & 0 & 0 & 0 & 0 & 0 \\
\hline & Unid & 0 & 0 & 0 & 0 & 0 & 0 \\
\hline & Total & 38 & 49 & 31 & 7 & 18 & 56 \\
\hline
\end{tabular}

a Unid $=$ plants that could not be identified to species.

Average Wetland Values and Prevalence Index Values. Table 12 lists the AWVs and PIVs for all species and for dominants only in the NAs and in the ROW. PIVs were all below 3.00, with most values below 2.50. PIVs for all species in the herb stratum in the NAs and the ROW were lower than the AWVs because OBL species were dominant. The PIVs for the shrub stratum were higher than the AWVs because of the dominance of the FAC species, American hornbeam, in the shrub stratum of the NAs. The sapling stratum had only FACW species as dominants, resulting in a PIV and an AWV of 2.00 for that stratum. Although the tree stratum had an overall AWV of 1.91, its leading dominant species was a FACW species, and the next two dominant species were FAC, yielding a PIV of 2.61 and an AWV of 2.67 for dominants only. The herb stratum in the ROW had the lowest PIV and AWV for all species (1.26 and 1.73, respectively). All dominant species in the herb stratum, both in the ROW and in the NAs, were OBL species; as a result, both areas had a PIV and an AWV of 1.00 for dominant species only. 
TABLE 10 Dominant Species by Vegetative Stratum for Each Area at the Brandy Branch Site

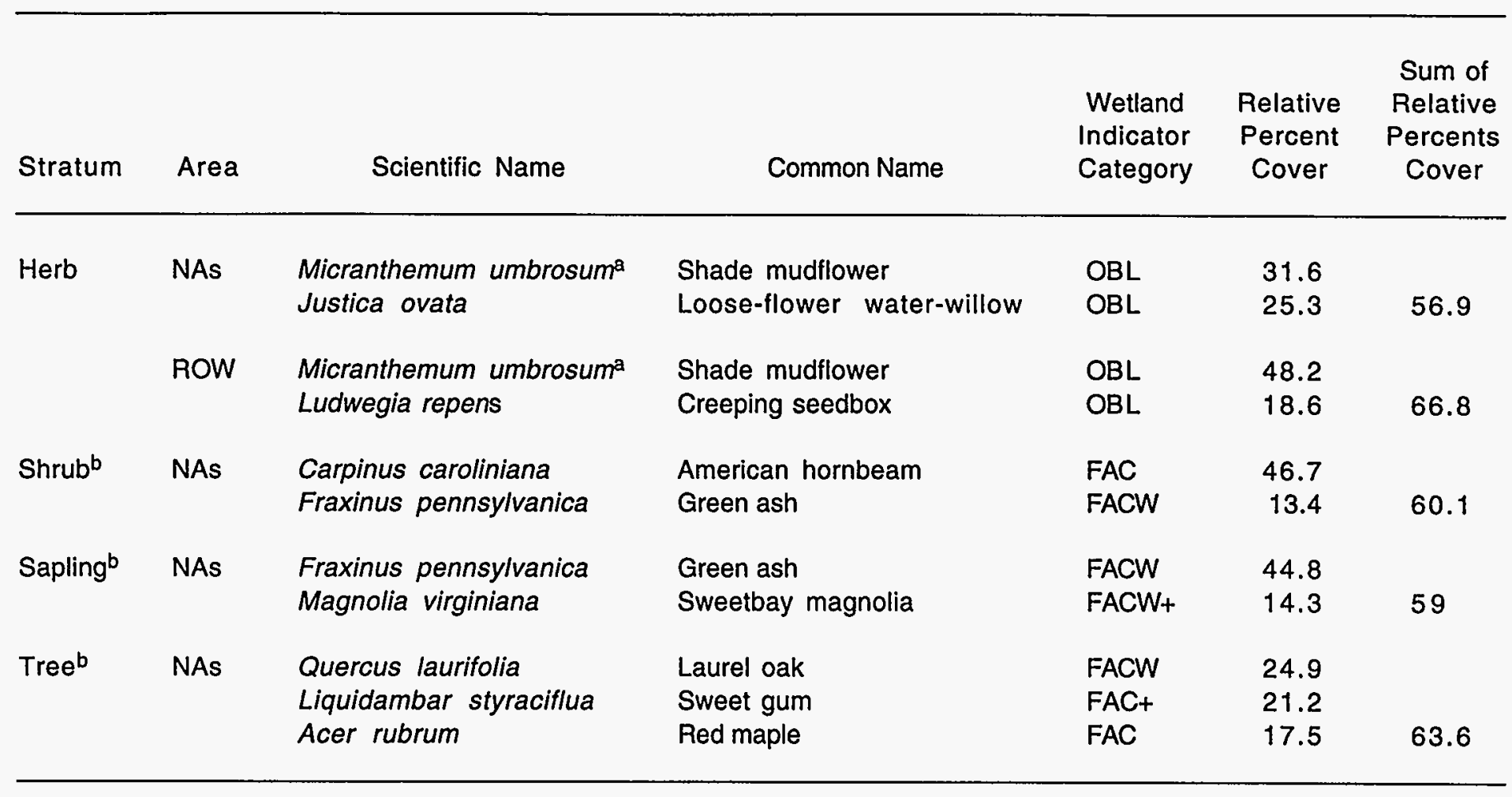

a Introduced species.

b Strata are not represented in the ROW. 
TABLE 11 Coefficient of Community Values Comparing Species Occurring in Study Plots at the Brandy Branch Site

\begin{tabular}{lccc}
\hline & \multicolumn{3}{c}{ Comparison } \\
\cline { 2 - 4 } Stratum & NAs to ROW & $\begin{array}{c}\text { West ROW to } \\
\text { East ROW }\end{array}$ & WNA to ENA \\
\hline Herb & 0.38 & 0.54 & 0.58 \\
Shrub & 0.00 & 0.00 & 0.89 \\
Sapling & 0.00 & 0.00 & 0.78 \\
Tree & 0.00 & 0.00 & 0.90 \\
Vine & 0.00 & 0.00 & 1.00 \\
Combined & 0.34 & 0.54 & 0.71 \\
\hline
\end{tabular}

TABLE 12 Prevalence Index and Average Wetland Values for All Species and Dominant Species in the NAs and the ROW (by individual stratum and combined strata) at the Brandy Branch Site

\begin{tabular}{|c|c|c|c|c|}
\hline Stratum & Area & Species & $\begin{array}{l}\text { Prevalence } \\
\text { Index Value }\end{array}$ & $\begin{array}{c}\text { Average } \\
\text { Wetland Value }\end{array}$ \\
\hline \multirow[t]{2}{*}{ Herb } & NAs & $\begin{array}{l}\text { All species } \\
\text { Dominants only }\end{array}$ & $\begin{array}{l}1.46 \\
1.00\end{array}$ & $\begin{array}{l}2.24 \\
1.00\end{array}$ \\
\hline & ROW & $\begin{array}{l}\text { All species } \\
\text { Dominants only }\end{array}$ & $\begin{array}{l}1.26 \\
1.00\end{array}$ & $\begin{array}{l}1.73 \\
1.00\end{array}$ \\
\hline Shrub & NAs & $\begin{array}{l}\text { All species } \\
\text { Dominants only }\end{array}$ & $\begin{array}{l}2.48 \\
2.77\end{array}$ & $\begin{array}{l}2.26 \\
2.50\end{array}$ \\
\hline Sapling & NAs & $\begin{array}{l}\text { All species } \\
\text { Dominants only }\end{array}$ & $\begin{array}{l}2.13 \\
2.00\end{array}$ & $\begin{array}{l}2.27 \\
2.00\end{array}$ \\
\hline Tree & NAs & $\begin{array}{l}\text { All species } \\
\text { Dominants only }\end{array}$ & $\begin{array}{l}2.24 \\
2.61\end{array}$ & $\begin{array}{l}1.91 \\
2.67\end{array}$ \\
\hline \multirow[t]{2}{*}{ Combined } & NAs & All species & $\mathrm{NC}^{\mathrm{a}}$ & 2.16 \\
\hline & ROW & All species & $N C$ & 1.73 \\
\hline
\end{tabular}

a Values could not be calculated because cover values are not additive. 


\section{Discussion}

\subsection{Deep Creek Study Site}

The use of directional horizontal drilling for pipeline installation at this site resulted in minimal disturbance to the ROW. Stumps, cut at ground level, remained in the ROW. Drainage patterns and ROW topography were unaltered. Clear-cutting of the ROW and subsequent removal of all slash with bulldozers constituted the major disturbances that contributed to the development of a new plant community in the ROW. Pipeline construction at this site was completed during May 1991.

By July 1992, slightly over one year after pipeline installation, a robust complement of plants had developed in the ROW. Plot samples in the herb stratum of the ROW included 73 species of plants, compared with 40 species of plants occurring in plots in the herb stratum of the adjacent NAs. Only $37 \%$ of the 74 ROW species occurred in adjacent NAs. Vegetation covered all of the soil surface within study plots. The only unvegetated areas observed within the ROW were the steep banks of stream channels that crossed the ROW. Because this site had been horizontally drilled, streams were not interrupted, riprap was not installed on their banks, and the area was not fertilized or seeded.

The ROW had both a greater number and a higher percent of annuals (13.7\%) and introduced species (9.6\%) than did the NAs, which had only $2 \%$ of each. The leading dominant in the ROW, shade mudflower, was an introduced perennial forb that is classified as an OBL wetland species. However, the low, matted growth form of this species makes it unlikely that it will remain dominant (Godfrey and Wooten 1981). The second leading dominant, bahia grass, is also an introduced species; it is classified as a FACU+ species. Bahia grass was probably introduced into the wetland from adjacent uplands, where it was seeded after pipeline installation. Four other species occurred as dominants. The fact that six different dominant species together had an RPC of $51 \%$ reflects good diversity in terms of species equitability.

Very little stump resprouting was observed. One green ash resprouted within one of the ROW plots. Maintenance plans prescribe the hand-removal of large woody species, as needed, to allow pipeline monitoring.

The ROW has quickly developed a relatively stable, dense vegetative cover consisting of $80 \%$ perennial species and having a sum of individual species cover of $130 \%$. Although $62 \%$ of the plants encountered in the ROW were unique to the ROW, the wetland indicator values were very close to those for the adjacent NAs. The PIVs and AWVs for the ROW, for all species and for dominant species only, were slightly lower than or equal to those for the NAs, reflecting a vegetative complex in the ROW that was at least as hydric as that of the adjacent NAs (both in terms of percent of wetland species in each category and in terms of the cover of wetland species). 


\subsection{Brandy Branch Study Site}

Pipeline installation at this site involved open trenching. The pipe was buried at a minimum depth of $3 \mathrm{ft}(0.91 \mathrm{~m})$. Although construction was completed during May 1991, final grading of the site was delayed until December 1991, when the site had less standing water. All equipment support (slash, mats, and corduroy pads) was removed before final grading. Two well-defined drainage channels crossed the ROW within this wetland. Sampling was carried out in the area between these drainage channels. Within the sampling site, between transects 2 and 3 , surface water occurred on the ROW, with a slight easterly flow. The ROW at this site varied in surface characteristics from well-drained surface soils to poorly consolidated water-saturated soils in the area of the shallow drainage.

At the time of sampling, July 1992, vegetation at this site covered $85.4 \%$ of the soil surface. A total of 38 species was present in the ROW plots, compared with 46 species in the herb stratum in the NAs. The total average percent cover of individual plant species was $103 \%$.

The two dominant species, shade mudflower and loose-flowered water-willow, accounted for $66.8 \%$ of the sum of cover of all species. Introduced species accounted for $13.1 \%$, and annuals accounted for $18.4 \%$, of the species occurring in sampling plots. One of the introduced perennials, Bahia grass, had been seeded on the adjacent uplands. The highest percents of exposed soil, $20 \%$ and $30 \%$, occurred in the two plots in transect 3 , which was at the edge of the shallow drainage and was extremely wet.

The high percent of perennials (79\%) in the ROW at this site should contribute to vegetative stability. However, because the shade mudflower has a prostrate growth form, it is possible that with time, soil consolidation, and reestablishment of drainage patterns (by erosion of small channels) in the ROW, taller plants will have an advantage and greatly reduce the mudflower cover from its present $48.2 \%$. The sum of cover for the herb stratum in the NAs at this site is higher than that at the Deep Creek site, while the percent relative cover for shade mudflower in the NAs is only $13.6 \%$. Thus, successional changes can be expected on the ROW within the next several years. However, if seasonal flooding is severe, such succession could be inhibited.

Both wetland values (the AWVs and PIVs) for all species and for dominants only indicate that the ROW vegetation is at least as hydric as that in the adjacent NAs. Values for all species in the herb stratum were lower for the ROW than for the NAs, while values for dominants were identical because only OBL dominants occurred in each. Values for the shrub, sapling, and tree strata in the NAs were higher than those for the herb stratum.

\subsection{Comparison of the Deep Creek and Brandy Branch Sites}

Both the Deep Creek and Brandy Branch sites are in bottomland, hardwood forests. The results of field sampling indicate similarities and differences in the natural communities at these two 
sites. The forest at the Brandy Branch site had larger trees with higher total basal area, less dense sapling and shrub strata, and fewer vines, but it also had greater total cover for herb stratum species.

Pipeline installation by horizontal drilling at the Deep Creek site was less disruptive to the ROW soil and made it possible to complete installation during May 1991. Open trenching at the Brandy Branch site resulted in mixing of the ROW soils. High water levels at the time of installation delayed final grading of the Brandy Branch site until December 1991.

At the time of sampling in mid-July 1991, the Deep Creek site had no surface water, except in deeper creek beds; the water surface in these creek beds was approximately $1 \mathrm{~m}$ below the surrounding floodplain surface. Although the floodplain surface at Brandy Branch was relatively flat, considerable variation occurred in its hydric characteristics. At Brandy Branch, water in the south drainage channel was approximately $30 \mathrm{~cm}$ below the adjacent floodplain, and water in the main channel (the north channel) was about $1 \mathrm{~m}$ below the floodplain surface. In the poorly defined drainage channel that occurred between transects 2 and 3 of the study site, the soils were poorly consolidated, and up to $10 \mathrm{~cm}$ of water covered the soil surface. However, the adjacent forest on either side of the ROW had no standing water, except in deeper channels. It appeared that water was seeping from the ground at the west edge of the ROW and draining into a channel just east of the ROW.

The Deep Creek site, which had minimal surface disturbance in the ROW, had developed a much more diverse and denser vegetative cover in the one year since pipeline installation. Almost twice as many species occurred in the sampling plots at the Deep Creek site as at the Brandy Branch site. The sum of the individual covers of all species was higher, and there was no unvegetated soil at the Deep Creek site. The percents of native and introduced species and of annuals and perennials were similar for the two sites. The leading dominant species at each site was the introduced perennial forb, shade mudflower. However, its average areal cover was more than twice as great at the Brandy Branch site as at the Deep Creek site (49.0\% vs. 24.4\%). Shade mudflower was particularly abundant in the wetter areas with poorly consolidated soils. Bahia grass, an introduced perennial grass, was present in the ROW at both sites.

The more hydric nature of the Brandy Branch site is reflected in lower AWVs and PIVs for its ROW vegetation compared with those for the Deep Creek site, even though both the AWVs and PIVs for the herb stratum in the NAs were lower at the Deep Creek site. Although installation activities probably caused slight topographic alterations, the preconstruction description indicated that a narrow slough occurred within the Brandy Branch area prior to construction.

The shorter time interval from last construction activity to sampling and the more hydric characteristics of the Brandy Branch site likely contributed to differences in the ROW vegetation between the two sites. However, had the Brandy Branch site been horizontally drilled, final grading at a later date might not have been necessary. Follow-up studies are needed to determine whether horizontal drilling shows similar advantages at other sites and, if so, how long such advantages persist. 


\section{Summary and Conclusions}

\subsection{Summary}

The primary goal of the GRI Wetland Corridors Program is to identify and evaluate the impacts of pipeline construction and ROW management on the wetlands they traverse. To accomplish this goal, pipelines crossing various wetlands throughout the eastern United States were surveyed. The objectives for each study site were to document the vegetative communities on the ROW and in the adjacent NAs that had not been disturbed by pipeline construction; to evaluate the similarities and differences between the plant communities on the ROW and those in the adjacent NAs; to document changes to the topography, soils, and hydrology attributable to ROW construction; and to identify impacts caused by ROW construction on rare, threatened, endangered, or sensitive species.

This study involved surveying the vegetation at two sites along a pipeline in southwest Nassau County, Florida, approximately one year after pipeline construction. The two sites were selected on the basis of their proximity to each other and because they have similar physical and vegetational characteristics; the primary difference between the two sites is that two different methods of pipeline installation were used at the sites. The pipeline at the Deep Creek site was installed by means of directional horizontal drilling, while the pipeline at the Brandy Branch site was installed by means of open trenching. Both sites were within well-developed floodplain forests.

Although the composition of the natural vegetation through which the ROW passed was similar at the two sites, the development of vegetation on the ROW was more advanced at the Deep Creek site in terms of total density and diversity. Several factors may have contributed to this phenomenon. First, the Deep Creek site was better drained; in terms of hydric characteristics, the soil surface of the ROW was similar to the soil in adjacent NAs, whereas the soil surface of the ROW at the Brandy Branch site was more hydric than in adjacent NAs. Second, directional horizontal drilling for pipeline installation did not disturb the soil at the Deep Creek site, but cropping the forest vegetation seemed to stimulate a flush of new growth from both seeds and rootstocks; on the other hand, trenching at the Brandy Branch site left some unconsolidated saturated soils at the surface that were not quickly revegetated. Third, the time interval since site closure for the Deep Creek site was 14 months, while the time interval since closure of the Brandy Branch site was only eight months.

At each site, the ROW was revegetated with predominantly native perennial wetland species, without artificial seeding, planting, or fertilization. Further vegetational succession can be anticipated at each site. Dominant species in the ROW at the Deep Creek site were all introduced species, and all were unique to the ROW. 


\subsection{Conclusions}

Both methods of pipeline installation resulted in ROW surfaces that were rapidly recolonized by predominantly native perennial plant species, resulting in relatively stable wetland plant communities. At each site, the ROW contributed to the vegetational diversity of the wetland. A relatively small component of the ROW species consisted of introduced species, one of which (Bahia grass) had been sown on the adjacent upland at each site; however, all dominant species in the ROW at the Deep Creek site were introduced species. No adverse effects caused by the presence of the ROW were observed in the NAs adjacent to the ROW.

Although several factors may have helped to promote the revegetation of the Deep Creek site, one factor, horizontal drilling, clearly enabled the rapid revegetation and stabilization of the ROW with predominantly desirable species, in terms of numbers. The comparatively less successful revegetation of the Brandy Branch site may be attributable to several factors as well, including the method of pipeline installation. Some of the difficulties encountered in final grading of the Brandy Branch site might have been avoided had it been horizontally drilled. Installing the pipeline during drier conditions might also have avoided these difficulties.

Although the horizontally drilled site had a more advanced vegetative community at the time of sampling, one cannot conclude from this study that horizontal drilling is a preferred method of pipeline installation through wetlands. Follow-up studies are needed on these and other comparable sites to determine the advantages, if any, of horizontal drilling in terms of reestablishing wetland vegetation in ROWs and how long such advantages might persist. These advantages must also be weighed against the additional costs of horizontal drilling. 


\section{References}

Bonham, C.P., 1989, Measurements for Terrestrial Vegetation, John Wiley and Sons, New York, N.Y.

Brower, J., J. Zar, and C. von Ende, 1990, Field and Laboratory Methods for General Ecology, Third Edition, Wm. C. Brown Publishers, Dubuque, Iowa.

Cowardin, L.M., et al., 1979, Classification of Wetlands and Deep Water Habitats of the United States, U.S. Fish and Wildlife Service, U.S. Geological Survey, and U.S. National Oceanic and Atmospheric Administration, Washington, D.C.

Federal Interagency Committee for Wetland Delineation (FICWD), 1989, Federal Manual for Identifying and Delineating Jurisdictional Wetlands, U.S. Army Corps of Engineers, U.S. Environmental Protection Agency, U.S. Fish and Wildlife Service, and U.S. Department of Agriculture, Washington, D.C., Cooperative Technical Publication.

Godfrey, R.K., and J.W. Wooten, 1981, Aquatic and Wetland Plants of the Southeastern United States, Dicotyledons, University of Georgia Press.

Reed, P.B., Jr., 1988, National List of Plant Species that Occur in Wetlands: Southeast (Region 2), Biology Report 88 (26.2), U.S. Department of Interior.

SCS: see Soil Conservation Service.

Soil Conservation Service, 1991a, Soil Survey of Nassau County, Florida, U.S. Department of Agriculture, in cooperation with the University of Florida, Institute of Food and Agricultural Sciences, Agricultural Experiment Stations and Soil Science Department, and Florida Department of Agriculture and Consumer Services.

Soil Conservation Service, 1991b, Hydric Soils of the United States, U.S. Department of Agriculture, in cooperation with the National Technical Committee for Hydric Soils.

Zimmerman, R.E., et al., 1991, Pipeline Corridors through Wetlands - Impacts on Plant and Avian Diversity: Boreal Wetlands, Oconto County, Wisconsin, GRI-91/0046, prepared by Argonne National Laboratory, Argonne, Ill., for the Gas Research Institute, Chicago, Ill. 


\section{Appendix A:}

Definition of Jurisdictional Wetlands 


\section{Appendix A: Definition of Jurisdictional Wetlands}

Wetland identification and delineation necessary to implement Section 404 of the Clean Water Act and the "Swampbuster" (Subtitle B) provision of the Food Security Act of 1985 involves four agencies: the U.S. Army Corps of Engineers (COE), the U.S. Environmental Protection Agency (EPA), the U.S. Fish and Wildlife Service (FWS), and the Soil Conservation Service (SCS). On January 10, 1989, these agencies, which had operated with slightly different definitions of wetland, adopted a uniform definition based on hydrology, vegetation, and soils.

The joint agreement stipulates that to be classified as a Jurisdictional Wetland, an area must have hydrotrophytic vegetation, hydric soils, and a wetland hydrology. All three criteria are mandatory; without any one criterion, the area is not a Jurisdictional Wetland. A schematic diagram of this delineation process is shown in Figure A.1. See the Federal Manual for Identifying and Delineating Jurisdictional Wetlands for a more detailed discussion of the various terms and criteria (FICWD 1989).

Problems uncovered during field trials of the 1989 Federal Manual and disagreement among the four agencies on revisions in 1991 resulted in the EPA and the COE reverting to use of the 1987 COE Wetlands Delineation Manual, which also defines wetlands on the basis of vegetation, hydric soils, and hydrology, but with slightly different definitions of these parameters. In January 1994, the four agencies entered into a joint Memorandum of Agreement, "Concerning the Delineation of Wetlands for Purposes of Section 404 of the Clean Water Act and Subtitle B of the Food Security Act," which, in broad terms, stipulates that the EPA and the COE will accept SCS procedures for delineating wetlands (SCS 1988) on agricultural lands and that SCS will use the 1987 COE Wetlands Delineation Manual (COE 1987) for areas that are not agricultural lands.

The individual reports on the pipeline crossings through wetlands that are part of the GRI Wetland Corridors Program use the definition and criteria of the 1989 Federal Manual that were in effect during 1990 and 1991, the first two years of these studies. The use of the rigorous criteria of the 1989 manual should provide sufficient information for application to other procedures in the evolving field regulatory procedures for delineation and preservation of jurisdictional wetlands.

\section{References}

COE: see U.S. Army Corps of Engineers.

Federal Interagency Committee for Wetland Delineation, 1989, Federal Manual for Identifying and Delineating Jurisdictional Wetlands, U.S. Army Corps of Engineers, U.S. Environmental Protection Agency, U.S. Fish and Wildlife Service, and U.S. Department of Agriculture, Cooperative Technical Publication, Washington, D.C.

FICWD: see Federal Interagency Committee for Wetland Delineation. 
SCS: see Soil Conservation Service.

Soil Conservation Service, 1988, National Food Security Act Manual, U.S. Department of Agriculture, Washington, D.C.

U.S. Army Corps of Engineers, 1987, Corps of Engineers Wetlands Delineation Manual, Technical Report Y-87-1, Waterways Experiment Station, Vicksburg, Miss.

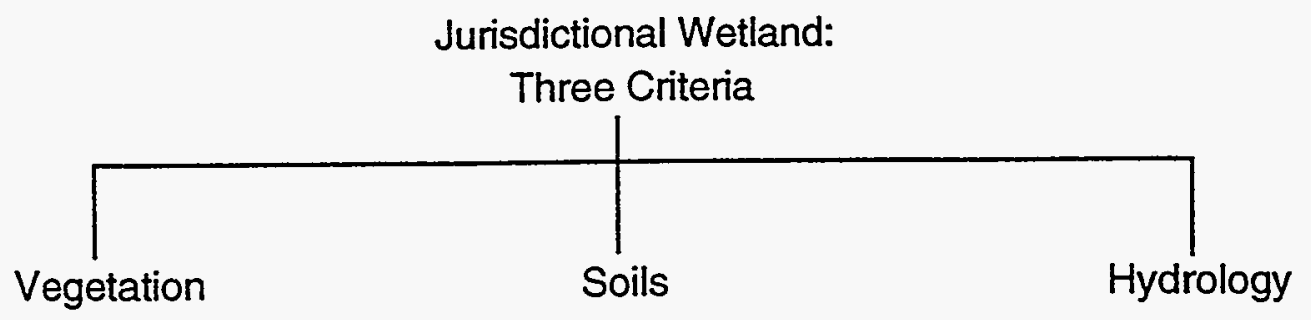

1. $50 \%$ dominant species OBL, FACW, and/or FAC

or

2. Prevalence Index $<3.0$

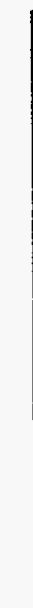

1. Saturated for 7 days or more during growing season

or

2. Flooded or ponded for 7 days or more during growing season

3. Soils ponded for 7 days or more during growing season

or

4. Soils frequently flooded for long duration during growing season

If all three criteria are met,

area is a regulated wetland

FIGURE A.1 Schematic Diagram of the Wetland Delineation Process (Source: FICWD 1989) 
Appendix B:

Data Analysis - Definitions and Equations 


\section{Appendix B: Data Analysis - Definitions and Equations}

\section{B.1 Wetland Indicator Categories}

Wetland indicator categories used in this report to classify the types of plant species were taken from Reed (1988). The five basic categories, commonly called the "wetland indicator status," are based on frequency of occurrence in wetlands. They are defined as follows:

\begin{tabular}{lll}
\multicolumn{1}{c}{ Category } & Value & \multicolumn{1}{c}{ Definition } \\
\hline $\begin{array}{l}\text { Obligate wetland (OBL) } \\
\text { Facultative wetland }\end{array}$ & 1.0 & $\begin{array}{l}\text { Plants that almost always occur in wetlands under } \\
\text { natural conditions (estimated probability >99\%) }\end{array}$ \\
$\begin{array}{l}\text { (FACW) } \\
\text { Facultative (FAC) }\end{array}$ & 3.0 & $\begin{array}{l}\text { Plants that usually occur in wetlands (estimated } \\
\text { probability 67-99\%) but occasionally are found in } \\
\text { nonwetlands }\end{array}$ \\
$\begin{array}{l}\text { Facultative upland } \\
\text { (FACU) }\end{array}$ & 4.0 & $\begin{array}{l}\text { Plants that are equally likely to occur in wetlands or } \\
\text { nonwetlands (estimated probability 34-66\%) }\end{array}$ \\
Obligate upland (UPL) & 5.0 & $\begin{array}{l}\text { Plants that usually occur in nonwetlands (estimated } \\
\text { probability 67-99\%) but occasionally are found in } \\
\text { wetlands (estimated probability 1-33\%) }\end{array}$ \\
\hline $\begin{array}{l}\text { Plants that almost always occur in nonwetlands under } \\
\text { natural conditions (estimated probability >99\%) }\end{array}$
\end{tabular}




\section{B.2 Life-Form and Origin}

The life-form and origin symbols are used for describing plant characteristics. The following symbols are used:

\begin{tabular}{ll}
\hline & \\
Symbol & Life-Form or Origin \\
\hline A & Annual \\
B & Biennial \\
E & Emergent \\
F & Forb \\
F3 & Fern \\
G & Grass \\
GL & Grasslike \\
H2 & Horsetail \\
I & Introduced \\
N & Native \\
P & Perennial \\
S & Shrub \\
T & Tree \\
V & Herbaceous vine \\
WV & Woody vine \\
\hline
\end{tabular}

Symbols are combined to describe the life-form and origin; for example, ANG means annual native grass and PIEF means perennial introduced emergent forb. For further description refer to the report by Reed (1988).

\section{B.3 Prevalence Index Value}

The prevalence index value (PIV) was determined by using the method outlined in the 1989 Federal Manual (FICWD 1989). The PIV, modified for this report to use relative percent areal coverage instead of relative frequencies as described in the 1989 Federal Manual, is defined as

$$
\mathrm{PIV}=\frac{R P C_{o}+2 R P C_{f w}+3 R P C_{f}+4 R P C_{f u}+5 R P C_{u}}{100}
$$

where

$$
\begin{aligned}
\mathrm{RPC}_{\mathrm{o}} & =\text { Relative percent coverage (RPC) of obligate wetland species, } \\
\mathrm{RPC}_{\mathrm{fw}} & =\mathrm{RPC} \text { of facultative wetland species, }
\end{aligned}
$$




$$
\begin{aligned}
\mathrm{RPC}_{\mathrm{f}} & =\mathrm{RPC} \text { of facultative species, } \\
\mathrm{RPC}_{\mathrm{fu}} & =\mathrm{RPC} \text { of facultative upland species, and } \\
\mathrm{RPC}_{\mathrm{u}} & =\mathrm{RPC} \text { of upland species. }
\end{aligned}
$$

\section{B.4 Average Wetland Value}

The average wetland value (AWV), defined in Zimmerman et al. (1991), differs from the PIV in that it is not coverage data or frequency of occurrence that is used in determining the AWV, but rather the total number of species present. Thus, all species present are represented equally in the AWV. The AWV is defined as

$$
A W V=\frac{N_{o}+2 N_{f w}+3 N_{f}+4 N_{f u}+5 N_{u}}{N_{o}+N_{f w}+N_{f}+N_{f u}+N_{u}}
$$

where

$$
\begin{aligned}
& N_{o}=\text { number of obligate wetland species, } \\
& N_{f w}=\text { number of facultative wetland species, } \\
& N_{f}=\text { number of facultative species, } \\
& N_{f u}=\text { number of facultative upland species, and } \\
& N_{u}=\text { number of upland species. }
\end{aligned}
$$

\section{B.5 References}

Federal Interagency Committee for Wetland Delineation, 1989, Federal Manual for Identifying and Delineating Jurisdictional Wetlands, U.S. Army Corps of Engineers, U.S. Environmental Protection Agency, U.S. Fish and Wildlife Service, and U.S. Department of Agriculture, Cooperative Technical Publication, Washington, D.C.

FICWD: see Federal Interagency Committee for Wetland Delineation. 
Reed, P.B., Jr., 1988, National List of Plant Species that Occur in Wetlands, Region 1, U.S. Department of the Interior, Biology Report 88 (26.1).

Zimmerman, R.E., et al., 1991, Pipeline Corridors through Wetlands - Impacts on Plant and Avian Diversity: Boreal Wetlands, Oconto County, Wisconsin, GRI-91/0046, prepared by Argonne National Laboratory, Argonne, Ill., for the Gas Research Institute, Chicago, Ill. 


\section{Appendix C:}

\section{Plant Species List, Areal Coverage Data,} and Species Distribution 


\title{
Appendix C:
}

\section{Plant Species List, Areal Coverage Data, and Species Distribution}

\author{
TABLE C.1 Plant Species List for the Deep Creek Site
}

\begin{tabular}{|c|c|c|c|c|}
\hline $\begin{array}{l}\text { Field } \\
\text { Number }\end{array}$ & Scientific Name and Authority & Common Name & $\begin{array}{l}\text { Region } 2 \\
\text { Wetland } \\
\text { Indicator } \\
\text { Category }\end{array}$ & $\begin{array}{l}\text { Life- } \\
\text { Form/ } \\
\text { Origin }^{b}\end{array}$ \\
\hline 19 & Acer rubrum $L$ & Red Maple & FAC & NT \\
\hline 57 & Andropogon capillipes Nash & Chalky Bluestem & FACU & PNG \\
\hline 115 & Arundinaria gigantea (Walter) Walter Ex Muhl. & Giant Cane & FACW & PNG \\
\hline 156 & Asimina parviflora (Michx.) Dunal & Dwarf Pawpaw & FACU & NST \\
\hline 140 & Baccharis halimifolia $L$. & Eastern False-Willow & FAC & NS \\
\hline 155 & Bignonia capreolata $L$. & Crossvine & FAC & NWV \\
\hline 49 & Boehmeria cylindrica (L.) Swartz & Small-Spike False-Nettle & FACW+ & PNF \\
\hline 128 & Campsis radicans (L.) Seem. & Trumpet-Creeper & FAC & NWV \\
\hline 150 & Carex albolutescens Schweinitz & Greenish-White Sedge & $\mathrm{FAC+}$ & PNGL \\
\hline 17 & Carex debilis Michx. & White-Edge Sedge & FACW & PNGL \\
\hline 83 & Carex glaucescens Elliott & Southern Waxy Sedge & OBL & PNEGL \\
\hline 124 & Carex howei Mackenz. & Howe Sedge & OBL & PNGL \\
\hline 123 & Carex lupulina Muhl. Ex Willd. & Hop Sedge & $\mathrm{OBL}$ & PNEGL \\
\hline 81 & Carex x stipata Muhl. Ex Willd. & Stalk-Grain Sedge & $\mathrm{OBL}$ & PNGL \\
\hline 22 & Carpinus caroliniana Walter & American Hombeam & FAC & NT \\
\hline 148 & Cassia fasciculata Michx. & Partridge Pea & FACU & ANF \\
\hline 75 & Cephalanthus occidentalis $L$. & Common Buttonbush & OBL & NT \\
\hline 116 & Chasmanthium laxum (L.) H. Yates & Slender Spikegrass & FACW- & PNG \\
\hline 159 & Crataegus aestivalis (Walter) Torr. \& Gray & May Hawthom & OBL & NT \\
\hline 55 & Crinum americanum $\mathrm{L}$. & Southern Swamplily & $\mathrm{OBL}$ & PNF \\
\hline 147 & Cuphea carthagenensis (Jacq.) J.F. Macbr. & Columbia Waxweed & FACW & AIF \\
\hline 130 & Cyperus odoratus $L$. & Rusty Flatsedge & FACW & APNGL \\
\hline 85 & Cyperus tenuifolius (Steud.) Dandy & Thin-Leaf Flatsedge & FACW & ANGL \\
\hline 12 & Cyperus virens Michx. & Green Flatsedge & FACW & PNEGL \\
\hline 40 & Cyrilla racemiflora $L$. & Swamp Cyrilla & FACW & NT \\
\hline 31 & Decumaria barbara $L$ & Southeast Decumaria & FACW & NWV \\
\hline 136 & Dichanthelium commutatum (J.A. Schultes) Gould & Variable Witchgrass & FAC & PNG \\
\hline 11 & Dichanthelium dichotomum (I.) Gould & Cypress Witchgrass & FAC & PNG \\
\hline 153 & Dichondra caroliniensis Michx. & Carolina Pony-Foot & FACW- & PNF \\
\hline 58 & Diodia virginiana $L$. & Virginia Button-Weed & FACW & APNEF \\
\hline 97 & Echinochloa colona (L.) Link & Jungle-Rice & FACW & $\mathrm{AIG}$ \\
\hline 113 & $\begin{array}{l}\text { Eleocharis tuberculosa (Michx.) Roem. \& } \\
\text { J.A. Schultes }\end{array}$ & Long-Tubercle Spikerush & FACW+ & PNGL \\
\hline 52 & Erechtites hieraciifolia (L.) Raf. Ex Dc. & American Bum & FAC & ANF \\
\hline 111 & Eryngium baldwinii Spreng. & Baldwin's Coyote-Thistle & FACW + & BNF \\
\hline 10 & Eupatorium capillifolium (Lam.) Small & $\begin{array}{l}\text { Small Dog-Fennel } \\
\text { Thorough-Wort }\end{array}$ & FACU & PNF \\
\hline 25 & Fraxinus caroliniana Mill. & Carolina Ash & OBL & NETS \\
\hline 24 & Fraxinus pennsylvanica Marshall & Green Ash & FACW & NT \\
\hline 50 & Fuirena brevisata Coville & Saltmarsh Umbrella-Sedge & OBL & PNGL \\
\hline 118 & Gelsemium sempervirens (L.) W.T. Ait. & Yellow Jessamine & FAC & NWVS \\
\hline 73 & Hydrocotvle umbellata $L$. & Many-Flower Penny-Wort & $\mathrm{OBL}$ & PNF \\
\hline 101 & Hydrolea quadrivalvis Walter & Water Pod & FACU & ANF \\
\hline 121 & Hypericum cistifolium Lam. & Round-Pod St. John's-Wort & FACW & ANF \\
\hline 44 & Hypericum mutilum $L$. & Slender St. John's-Wort & FACW & PNF \\
\hline 38 & Hypoxis leptocarpa (Engelm. \& Gray) Engelm. & Clubpod Goldstar & FACW & PNEF \\
\hline
\end{tabular}


TABLE C.1 (Cont.)

\begin{tabular}{|c|c|c|c|c|}
\hline $\begin{array}{l}\text { Field } \\
\text { Number }\end{array}$ & Scientific Name and Authority & Common Name & $\begin{array}{l}\text { Region } 2 \\
\text { Wetland } \\
\text { Indicator } \\
\text { Category }\end{array}$ & $\begin{array}{l}\text { Life- } \\
\text { Form/ } \\
\text { Origin }^{b}\end{array}$ \\
\hline 126 & Ilex cassine $L$. & Dahoon Holly & UPL & NS \\
\hline 27 & Ilex opaca Soland. In Ait & American Holly & FAC & NTS \\
\hline 14 & Itea virginica $L$ & Virginia Willow & FACW+ & NS \\
\hline 109 & Juncus coriaceus Mackenz. & Leathery Rush & FACW & PNGL \\
\hline 91 & Juncus effusus $L$. & Soft Rush & FACW+ & PNEGL \\
\hline 103 & Juncus marginatus Rostk. & Grass-Leaf Rush & FACW & PNGL \\
\hline 132 & Juncus polycephalus Michx. & Many-Head Rush & $\mathrm{OBL}$ & PNGL \\
\hline 33 & Justicia ovata (Walter) Lindau & Loose-Flower Water-Willow & $\mathrm{OBL}$ & PNF \\
\hline 122 & Leucothoe axillaris (Lam.) D. Don & Coastal Dog-Hobble & FACW & NS \\
\hline 35 & Liquidambar styraciflua $L$. & Sweet Gum & $\mathrm{FAC+}$ & NT \\
\hline 152 & Ludwigia altemifolia $L$. & Bushy Seedbox & OBL & PNEF \\
\hline 4 & Ludwigia repens J. Forst. & Creeping Seedbox & OBL & PNEF \\
\hline 96 & Ludwigia sp. & & & \\
\hline 146 & Magnolia granidflora $L$. & Large-Flower Magnolia & FACU & NT \\
\hline 34 & Magnolia virginiana $L$ & Sweetbay Magnolia & FACW+ & NT \\
\hline 138 & Mecardonia acuminata (Walter) Small & Purple Mecardonia & FACW & PNF \\
\hline 1 & Micranthemum umbrosum (Walter) Blake & Shade Mudflower & OBL. & PIF \\
\hline 51 & Mikania scandens (L.) Willd. & Climbing Hempweed & FACW+ & PNV \\
\hline 20 & Mitchella repens $L$. & Partridge-Berry & FACU+ & PNF \\
\hline 141 & Myrica cerifera $L$ & Southern Bayberry & FAC+ & NST \\
\hline 29 & Nyssa ogeche W. Bartram Ex Marshall & Ogeechee Tupelo & OBL & NT \\
\hline 133 & Oldenlandia uniflora $L$ & Clustered Bluet & FACW- & AlF \\
\hline 119 & Panicum hemitomon J.A. Schultes & Maiden-Cane & OBL & PNEG \\
\hline 42 & Paspalum notatum Fluegge & Bahia Grass & FACUt & PXG \\
\hline 110 & Phyla nodiflora (L.) Greene & Common Frog-Fruit & FACW & PNF \\
\hline 162 & Pinus taeda $L$. & Loblolly Pine & FAC & NT \\
\hline 154 & Pluchea camphorata (L.) Dc. & Salt Marsh Camphor-Weed & FACW & APIF \\
\hline 95 & Pluchea foetida (L.) DC. & Stinking Camphor-Weed & OBL & PNF \\
\hline 131 & Pluchea rosea R.K. Godfr. & Rosy Camphor-Weed & FACW & PNF \\
\hline 160 & Polygala lutea $L$. & Orange Milkwort & $\mathrm{FACW}_{+}$ & $B N F$ \\
\hline 107 & Polygonum opelousanum Riddell Ex Small & Little Water Pepper & OBL & PNF \\
\hline 102 & Polypremum procumbens $L$. & Juniper-Leaf & FACU & APNF \\
\hline 44 & Pontederia cordata $L$. & Pickerel Weed & OBL & PNEF \\
\hline 120 & Ptilimnium capillaceum (Michx.) Raf. & $\begin{array}{l}\text { Hair-Like Mock } \\
\text { Bishop-Weed }\end{array}$ & OBL & ANEF \\
\hline 39 & Quercus laurifolia Michx. & Laurel Oak & FACW & NT \\
\hline 30 & Quercus michauxii Nutt. & Swamp Chestnut Oak & FACW- & NT \\
\hline 135 & Quercus nigra $L$. & Water Oak & FAC & NT \\
\hline 114 & Rhexia mariana $L$. & Maryland Meadow-Beauty & FACW+ & PNF \\
\hline 104 & Rhynchospora caduca Elliott & Falling Beakrush & OBL & PNGL \\
\hline 112 & Rhynchospora fascicularis (Michx.) Vahl & Fasciculate Beakrush & FACW+ & PNGL \\
\hline 77 & Rubus argutus Link & Serrate-Leaf Blackberry & FACUt & NS \\
\hline 134 & Sabal minor (Jacq.) Pers. & Dwarf Palmetto & FACW & NST \\
\hline 129 & Sagittaria Iancifolia $L$. & Bull-Tongue Arrow-Head & OBL & PNEF \\
\hline 63 & Saururus cernuus $L$. & Lizard's Tail & $\mathrm{OBL}$ & PNEF \\
\hline 43 & Scirpus cyperinus (L.) Kunth & Wool-Grass & OBL & PNEGL \\
\hline 142 & Scleria triglomerata Michx. & Whip Nutrush & FACU+ & PNGL \\
\hline 139 & Scoparia dulcis $L$. & Licorice Weed & FAC & AlF \\
\hline 137 & Smilax bona-nox L. & Saw Greenbrier & FAC & NHV \\
\hline 145 & Smilax glauca Walter & Cat Greenbrier & FAC & NSWV \\
\hline 21 & Smilax rotundifolia $L$ & Common Greenbrier & FAC & NWV \\
\hline 98 & Taxodium distichum (L.) L.C. Rich. & Bald Cypress & OBL & NET \\
\hline 151 & Trifolium repens $L$. & White Clover & FACU & PIF \\
\hline 161 & Toxicodendron radicans $(L)$ Knutz & Poison Ivy & FAC & NVS \\
\hline 99 & Unknown grass & & & \\
\hline
\end{tabular}


TABLE C.1 (Cont.)

\begin{tabular}{rllll}
\hline $\begin{array}{c}\text { Field } \\
\text { Number }\end{array}$ & \multicolumn{1}{c}{ Scientific Name and Authority } & Common Name & $\begin{array}{c}\text { Region 2 } \\
\text { Wetland } \\
\text { Indicator } \\
\text { Category }\end{array}$ & $\begin{array}{c}\text { Life- } \\
\text { Form/ } \\
\text { Origin }\end{array}$ \\
\hline & Vaccinium elliottii Chapm. & Elliott Blueberry & FAC+ & NS \\
143 & Viola esculenta Elliott & Edible Violet & FACW- & PNF \\
125 & Muscadine Grape & FAC & NWV \\
60 & Vitis rotundifolia Michx. & Netted Chainfern & OBL & PNEF3 \\
79 & Woodwardia areolata (L.) T. Moore & Virginia Chainfern & OBL & PNF3 \\
59 & Woodwardia virginica (L.) J.E. Smith & & & \\
108 & Xyris sp. & & & \\
\end{tabular}

a Wetland indicator categories are assigned to plants in the United States on a regional basis. Florida is located in Region 2. A ' + ' following an indicator indicates a frequency toward the high end of the category (more frequently found in wetlands), while a '-' indicates a frequency toward the low end (less frequently found in wetlands).

b Plant characteristics and life-forms assigned to each species are indicated in this column. 
TABLE C.2 Cover Estimates for Each Species by Stratum, Deep Creek Site

\begin{tabular}{|c|c|c|c|c|c|c|c|c|c|c|c|c|c|c|c|c|c|c|c|c|c|}
\hline \multirow{3}{*}{$\begin{array}{l}\text { Field } \\
\text { Number }\end{array}$} & \multirow[b]{3}{*}{ Species Name } & \multicolumn{20}{|c|}{ Areal Cover ${ }^{\mathrm{a}}(\%)$} \\
\hline & & \multicolumn{5}{|c|}{ South Natural Area } & \multicolumn{5}{|c|}{ South ROW Area } & \multicolumn{5}{|c|}{ North ROW Area } & \multicolumn{5}{|c|}{ North Natural Area } \\
\hline & & $\mathrm{T} 1$ & $\mathrm{~T} 2$ & T3 & $T_{4}$ & T5 & T1 & $\mathrm{T} 2$ & T3 & T4 & T5 & T1 & T2 & T3 & $\mathrm{T}_{4}$ & T5 & T1 & $\mathrm{T} 2$ & T3 & $\mathrm{T}_{4}$ & T5 \\
\hline
\end{tabular}

HERB STRATUM

Acer rubrum

Andropogon capillipos

Arundinaria gigantoa

Asimina parviflora

Baccharis halimifolia

Bignonia capreolata

Boehmeria cyllndrica

Campsis radlcans

Carex albolutescens

Carex debills

Carex glaucescens

Carex howel

Carex lupulina

Carpinus caroliniana

Cassia fasciculata

Cephalanthus occidentalis

Chasmanthium laxum

Crinum americanum

Cuphea carthagenens/s

Cyperus odoratus

Cyporus tenuifolius

Cyperus virens

Decumaria barbara

Dichanthelium commutatum

Dichanthelium dichotomum

Dichondra carolinionsis

Diodia virginiana

Echinochloa colona

Eleocharis tuberculosa

Erechtites hieraciifolla

Eryngium baldwinii

Eupatorium capillifolium

Fuirena brovisata

Gelsemium sempervirens

Hydrocotyle umbellate

Hydrolea quadrivalvis

Hypericum cistifolium

Hypericum mutilum

\begin{tabular}{|c|c|c|c|c|c|c|c|c|c|c|c|c|c|c|}
\hline - & - & - & - & - & - & - & - & - & - & - & - & - & - & . \\
\hline$\cdot$ & - & $\cdot$ & - & - & - & - & 0.5 & - & 5 & - & - & - & - & - \\
\hline 30 & - & - & 0.5 & - & - & - & - & - & . & - & - & - & 1 & . \\
\hline$\cdot$ & - & . & - & - & - & - & - & - & - & - & - & - & . & - \\
\hline - & - & - & - & - & - & - & - & - & - & - & • & - & . & - \\
\hline - & - & 0.5 & - & - & $\cdot$ & - & - & - & - & - & - & - & - & - \\
\hline - & - & - & - & - & 0.5 & - & 0.5 & - & . & 0.5 & - & . & - & . \\
\hline - & - & - & 2 & - & • & - & - & 0.5 & • & • & - & - & 0.5 & • \\
\hline - & - & - & - & - & $\cdot$ & - & - & 0.5 & • & - & - & - & 2 & " \\
\hline - & - & - & - & - & • & - & - & - & - & $\cdot$ & $\therefore$ & - & - & - \\
\hline - & - & . & 0.5 & - & - & - & - & - & • & - & 10 & - & - & • \\
\hline - & - & - & - & - & - & - & - & - & - & - & - & - & - & - \\
\hline - & - & - & - & - & - & - & - & - & - & - & 2 & 2 & 8 & - \\
\hline - & - & - & - & - & - & - & - & - & - & - & 0.5 & - & - & - \\
\hline - & - & - & - & - & - & - & - & - & 0.5 & - & - & . & - & - \\
\hline - & - & $\cdot$ & - & - & - & - & - & 0.5 & - & - & - & 0.5 & - & - \\
\hline - & - & - & - & 0.5 & 2 & 8 & 0.5 & 5 & 0.5 & 2 & 2 & 1 & 0.5 & - \\
\hline 3 & 40 & 30 & 20 & 15 & - & - & - & 0.5 & 2 & - & $\cdot$ & 2 & 0.5 & 2 \\
\hline - & $\cdot$ & $\cdot$ & - & - & - & - & - & - & - & . & - & - & $\cdot$ & - \\
\hline - & - & - & - & - & - & " & - & - & - & - & - & 2 & - & - \\
\hline - & - & - & - & - & - & - & - & - & - & - & 5 & - & - & - \\
\hline - & - & - & - & - & 0.5 & - & - & - & - & 0.5 & • & - & - & . \\
\hline - & - & • & - & - & 5 & 30 & $=$ & 10 & - & 5 & 5 & - & - & - \\
\hline - & 0.5 & - & - & - & - & - & - & - & - & - & . & - & . & - \\
\hline 0.5 & - & $\cdot$ & - & 1 & • & $\cdot$ & - & - & - & - & - & - & - & 10 \\
\hline - & 5 & - & 0.5 & 0.5 & 5 & 5 & - & 5 & - & - & 50 & 10 & 0.5 & 5 \\
\hline$\cdot$ & - & - & $\cdot$ & • & - & • & 0.5 & - & - & - & - & • & - & - \\
\hline$\cdot$ & - & - & - & - & - & $\cdot$ & - & - & - & - & - & . & 0.5 & - \\
\hline - & - & - & - & - & 0.5 & 0.5 & • & 0.5 & - & - & 0.5 & - & 3 & - \\
\hline & - & - & - & - & 2 & • & 5 & $\cdot$ & - & 2 & - & - & • & - \\
\hline - & - & - & - & - & 1 & 10 & 5 & 2 & 15 & 2 & 5 & 15 & 3 & 3 \\
\hline - & - & - & - & - & 0.5 & • & $\cdot$ & 5 & 3 & - & - & $\cdot$ & 0.5 & 5 \\
\hline - & - & - & $\cdot$ & - & 2 & 5 & - & 3 & 15 & 2 & - & 2 & 1 & 25 \\
\hline$\cdot$ & - & - & - & - & - & 5 & - & $\cdot$ & 5 & 5 & 2 & - & 1 & 7 \\
\hline - & 0.5 & - & - & - & - & - & - & $\cdot$ & - & 0.5 &. & - & - & 0.5 \\
\hline - & • & - & $\cdot$ & - & 1 & - & $\cdot$ & 0.5 & - & - & - & - & 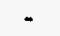 & $\cdot$ \\
\hline - & • & - & $\cdot$ & - & 2 & - & 1 & 5 & - & - & 7 & 1 & 15 & - \\
\hline - & 0.5 & - & - & 0.5 & 0.5 & 1 & 2 & 2 & 20 & 0.5 & - & 10 & 2 & 25 \\
\hline - & - & - & - & • & - & - & 5 & • & $\cdot$ & - & - & - & - & - \\
\hline
\end{tabular}




\begin{tabular}{|c|c|c|c|c|c|c|c|c|c|c|c|c|c|c|c|c|c|c|c|c|c|}
\hline \multirow{3}{*}{$\begin{array}{l}\text { Field } \\
\text { Number }\end{array}$} & \multirow{3}{*}{ Species Name } & \multicolumn{20}{|c|}{ Areal Cover $(\%)$} \\
\hline & & \multicolumn{5}{|c|}{ South Natural Area } & \multicolumn{5}{|c|}{ South ROW Area } & \multicolumn{5}{|c|}{ North ROW Area } & \multicolumn{5}{|c|}{ North Natural Area } \\
\hline & & $\mathrm{T} 1$ & T2 & T3 & T4 & T5 & $\mathrm{T} 1$ & T2 & T3 & $T_{4}$ & T5 & T1 & T2 & T3 & T4 & T5 & T1 & T2 & T3 & T4 & T5 \\
\hline 38 & Hypoxis leptocarpa & 0.5 & - & - & 1 & - & 0.5 & - & - & - & - & - & - & - & - & - & 3 & - & - & - & - \\
\hline 14 & Itea virginica & $\cdot$ & - & - & $\cdot$ & - & - & - & - & - & - & - & - & - & $\cdot$ & - & - & - & - & 5 & - \\
\hline 109 & Juncus coriaceus & - & - & - & - & - & 20 & 20 & 25 & 5 & - & 15 & - & - & 5 & - & - & - & - & - & - \\
\hline 91 & Juncus offusus & - & - & - & - & - & - & 5 & $\cdot$ & - & - & $\cdot$ & - & - & $\cdot$ & - & - & - & - & - & - \\
\hline 103 & Juncus marginatus & - & - & - & - & - & 2 & - & 20 & 5 & - & - & 5 & 25 & 5 & 5 & - & - & - & - & - \\
\hline 132 & Juncus polycephalus & - & - & - & - & $\cdot$ & 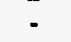 & 0.5 & - & - & - & - & 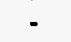 & - & - & 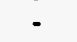 & - & - & - & - & - \\
\hline 33 & Justicia ovata & - & 0.5 & - & - & 15 & - & - & - & - & - & - & - & - & - & - & - & 0.5 & - & 5 & - \\
\hline 122 & Leucothoo axillaris & $\cdot$ & - & - & - & - & - & - & - & - & - & - & - & - & - & - & 0.5 & - & - & - & - \\
\hline 35 & Liquidambar styraciflua & - & - & - & - & - & - & - & - & - & - & - & - & - & - & - & 1 & - & - & - & - \\
\hline 152 & Ludwigia alternifolia & - & - & - & - & - & - & - & - & 1 & - & - & - & - & - & - & - & - & - & - & - \\
\hline 4 & Ludwegia repens & - & - & - & - & - & - & - & - & 10 & - & - & $\cdot$ & - & - & $\cdot$ & $\cdot$ & $\cdot$ & - & - & - \\
\hline 96 & Ludwigia sp. & - & - & - & - & - & 2 & - & - & 0.5 & - & 1 & - & - & - & - & 0.5 & - & - & - & - \\
\hline 138 & Mecardonia acuminata & - & - & - & - & - & 0.5 & - & 0.5 & - & - & - & - & 0.5 & 0.5 & - & - & - & - & - & - \\
\hline 1 & Micranthemum umbrosum & - & - & - & - & - & 60 & 60 & 5 & 25 & - & 50 & 2 & - & 40 & - & - & - & - & - & - \\
\hline 51 & Mikania scandens & - & - & . & - & - & - & - & - & - & - & - & - & - & 5 & - & . & - & - & - & - \\
\hline 20 & Mitchella repens & 0.5 & 0.5 & - & - & 0.5 & - & - & - & - & - & - & - & - & 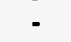 & - & - & - & - & 0.5 & - \\
\hline 141 & Myrica cerifera & - & - & - & - & - & - & - & - & - & - & - & - & - & - & 2 & - & - & - & - & - \\
\hline 133 & Oldenlandia uniflora & - & - & - & - & - & - & 0.5 & - & - & - & - & - & - & - & 0.5 & - & $\cdot$ & - & - & - \\
\hline 119 & Panicum hemitomon & - & - & - & - & - & - & $\because$ & . & 0.5 & 10 & 5 & - & - & 2 & 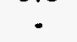 & - & 0.5 & - & - & - \\
\hline 42 & Paspalum notatum & - & - & - & - & 0.5 & - & 10 & - & 10 & 1 & 25 & - & 15 & 50 & 1 & - & - & - & - & - \\
\hline 110 & Phyla nodiflora & - & - & - & - & - & 0.5 & - & - & $\cdot$ & : & 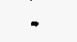 & - & - & - & : & - & - & - & - & - \\
\hline 162 & Pinus taeda & - & - & 0.5 & - & - & $\cdot$ & - & - & - & - & - & - & - & - & - & - & - & - & - & - \\
\hline 154 & Pluchea camphorata & - & - & - & - & - & - & - & 1 & - & - & - & - & - & - & - & - & - & - & - & - \\
\hline 95 & Pluchea footida & - & - & - & - & - & 6 & 5 & 2 & 5 & $\cdot$ & 6 & $\cdot$ & 20 & 2 & 2 & - & - & - & - & - \\
\hline 131 & Pluchea rosea & - & - & - & - & - & - & - & - & - & 0.5 & . & 0.5 & - & $\cdot$ & - & - & - & - & - & - \\
\hline 160 & Polygala lutea & - & - & - & - & - & - & - & - & - & $\cdot$ & $\cdot$ & - & $\cdot$ & 0.5 & - & - & - & - & $\cdot$ & - \\
\hline 107 & Polygonum opelousanum & - & - & - & - & - & 3 & - & $\cdot$ & 0.5 & - & 25 & 4 & 0.5 & 10 & - & 0.5 & - & - & - & - \\
\hline 102 & Polypremum procumbens & $\cdot$ & - & - & - & - & 1 & 5 & 20 & 5 & 15 & - & - & 5 & 0.5 & 15 & $\because$ & - & - & - & - \\
\hline 44 & Pontederia cordata & - & - & - & - & - & : & - & - & - & - & - & - & - & - & - & - & - & - & - & - \\
\hline 120 & Ptilimnium capillaceum & - & - & - & - & - & - & - & - & - & - & 1 & - & - & - & - & - & - & - & - & - \\
\hline 39 & Quercus laurifolla & 0.5 & 0.5 & - & - & 0.5 & - & - & - & 0.5 & - & - & 0.5 & - & * & - & - & 0.5 & - & - & 1 \\
\hline 30 & Quercus michauxil & - & 1 & - & - & - & - & - & - & $\cdot$ & - & - & - & - & - & - & - & - & - & - & - \\
\hline 114 & Rhexia mariana & - & . & - & - & - & - & - & - & - & - & - & - & - & - & 0.5 & - & - & - & - & - \\
\hline 104 & Rhynchospora caduca & - & - & - & - & - & 5 & - & - & - & - & 5 & - & - & - & - & - & - & - & - & - \\
\hline 122 & Rhynchospora fasclcularis & - & - & - & - & . & 1 & - & - & . & - & - & - & - & - & - & - & - & - & - & - \\
\hline 77 & Rubus argutus & - & - & - & - & - & : & - & - & - & 0.5 & - & - & - & - & 0.5 & 0.5 & - & - & - & - \\
\hline 134 & Sabal minor & - & - & - & - & - & - & - & - & - & - & - & - & - & - & - & - & - & - & - & - \\
\hline 129 & Sagittaria lancifolia & - & . & . & - & . & - & 0.5 & - & 2 & - & - & 0.5 & - & 0.5 & . & - & - & - & . & - \\
\hline 63 & Saururus cernuus & - & - & - & - & - & - & - & - & - & - & 0.5 & - & - & - & - & - & - & - & - & - \\
\hline 43 & Scirpus cyperinus & - & - & - & - & - & 20 & 5 & 15 & 15 & - & - & 20 & 5 & 2 & - & - & - & - & . & - \\
\hline 142 & Scleria triglomerata & - & - & 0.5 & 0.5 & - & - & - & - & $\cdot$ & 1 & - & - & - & - & - & - & - & - & - & - \\
\hline
\end{tabular}




\begin{tabular}{|c|c|c|c|c|c|c|c|c|c|c|c|c|c|c|c|c|c|c|c|c|c|}
\hline \multirow{3}{*}{$\begin{array}{l}\text { Field } \\
\text { Number }\end{array}$} & \multirow[b]{3}{*}{ Specles Name } & \multicolumn{20}{|c|}{ Areal Cover ${ }^{a}(\%)$} \\
\hline & & \multicolumn{5}{|c|}{ South Natural Area } & \multicolumn{5}{|c|}{ South ROW Area } & \multicolumn{5}{|c|}{ North ROW Area } & \multicolumn{5}{|c|}{ North Natural Area } \\
\hline & & $\mathrm{T1}$ & T2 & T3 & $\mathrm{T4}$ & T5 & $T 1$ & $\mathrm{~T} 2$ & T3 & $\mathrm{T4}$ & T5 & T1 & T2 & T3 & T4 & T5 & $\mathrm{T} 1$ & T2 & T3 & $\mathrm{T} 4$ & T5 \\
\hline 139 & Scoparla dulc/s & - & - & - & - & - & - & - & - & - & 5 & - & - & 0.5 & 0.5 & 0.5 & - & - & - & - & - \\
\hline 137 & Smilax bona-nox & - & - & 1 & 1 & 1 & - & - & - & - & - & - & - & - & - & 0.5 & - & - & - & 15 & 0.5 \\
\hline 145 & Smilax glauca & - & - & - & - & - & - & - & - & 0.5 & - & - & - & - & - & - & - & - & - & - & - \\
\hline 21 & Smilax rotundifolla & 0.5 & - & - & - & . & - & - & - & - & - & - & - & - & - & - & - & - & - & - & - \\
\hline 98 & Taxodium distichum & - & . & . & - & - & - & - & . & - & . & 1 & - & - & - & - & - & - & - & - & - \\
\hline 151 & Trifollum repens & - & - & - & - & - & - & - & - & 0.5 & - & - & - & - & 0.5 & - & - & - & - & - & - \\
\hline 99 & Unknown grass & - & - & - & - & - & 10 & 5 & - & 10 & - & - & 5 & 5 & 0.5 & - & - & - & - & . & - \\
\hline 143 & Vaccinium elliottii & - & - & 0.5 & - & - & - & - & - & - & - & - & - & - & - & - & - & - & - & - & 5 \\
\hline 125 & Viola esculenta & - & 0.5 & - & - & 0.5 & - & - & - & - & - & - & 0.5 & - & - & - & - & 0 & - & 0.5 & - \\
\hline 60 & Vitls rotundifolia & - & - & 0.5 & - & - & - & - & - & - & 0.5 & - & - & - & - & - & 1 & 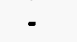 & - & - & 0.5 \\
\hline 79 & Woodwardia areolata & - & - & - & - & - & - & - & - & - & - & - & - & - & - & - & 0.5 & - & - & - & - \\
\hline 59 & Woodwardia virginica & - & . & - & - & - & - & - & . & 0.5 & - & - & - & - & - & - & - & - & - & - & - \\
\hline \multirow[t]{2}{*}{108} & Xyris sp. & $\cdot$ & 0.5 & $\cdot$ & - & - & 1 & - & 0.5 & 0.5 & $\cdot$ & 4 & 2 & - & 1 & $\cdot$ & - & - & - & $\cdot$ & - \\
\hline & SHRUB STRATUM & & & & & & & & & & & & & & & & & & & & \\
\hline 19 & Acer rubrum & - & - & 5 & 2 & - & - & - & - & - & - & - & - & - & - & - & 2 & - & 1 & 2 & 0.5 \\
\hline 22 & Carplnus caroliniana & 80 & 30 & 2 & 10 & 30 & - & - & - & - & - & - & - & - & - & - & 5 & 40 & 10 & 10 & 60 \\
\hline 75 & Cophalanthus occidentalis & - & - & - & - & - & - & - & - & - & - & - & - & - & - & - & - & - & - & 0.5 & 0.5 \\
\hline 159 & Crataegus aestivalis & - & - & - & - & - & - & - & - & - & - & - & - & - & - & - & - & - & - & 1 & - \\
\hline 40 & Cyrilla racemiflora & - & 0.5 & - & - & 1 & - & - & - & - & - & - & - & - & - & - & 1 & - & - & 1 & 0.5 \\
\hline 25 & Fraxinus caroliniana & - & 2 & - & - & 1 & . & - & - & - & - & - & - & - & - & - & - & 2 & 1 & - & 2 \\
\hline 24 & Fraxinus pennsy/vanica & 1 & - & - & - & - & - & - & - & - & - & - & - & - & - & 3 & - & - & - & - & - \\
\hline 27 & Hex opaca & - & 1 & 2 & 2 & 1 & - & - & - & - & - & - & - & - & - & - & - & - & - & - & 1 \\
\hline 35 & Llquidambar styracillua & - & 2 & 1 & - & 1 & - & - & - & - & - & - & - & . & - & - & - & - & - & - & - \\
\hline 34 & Magnolia virginiana & 1 & - & - & - & - & - & - & - & - & - & - & - & - & - & - & - & - & - & - & - \\
\hline 141 & Myrica cerifera & - & 1 & - & - & 1 & - & - & - & - & - & - & - & - & - & - & - & - & - & - & - \\
\hline 29 & Nyssa ogeche & 1 & 0.5 & 1 & 2 & - & - & - & - & - & - & - & - & - & - & - & - & - & - & - & - \\
\hline 39 & Quercus laurifolia & - & - & - & 2 & - & - & - & - & - & - & - & - & - & - & - & - & - & - & - & 2 \\
\hline 98 & Taxodium distichum & - & - & - & 1 & - & - & . & - & - & - & - & - & - & - & - & - & 1 & - & - & - \\
\hline \multirow[t]{2}{*}{143} & Vaccinium elliottil & $\cdot$ & $\cdot$ & $\cdot$ & $\cdot$ & 2 & $\cdot$ & $\cdot$ & - & - & - & - & $\cdot$ & $\cdot$ & $\cdot$ & $\cdot$ & $\cdot$ & - & - & - & 15 \\
\hline & SAPLNG STRATUM & & & & & & & & & & & & & & & & & & & & \\
\hline 19 & Acer rubrum & - & - & - & - & - & - & - & - & - & - & - & . & - & - & - & 3 & - & - & - & 5 \\
\hline 22 & Carpinus caroliniana & 10 & 40 & 1 & - & 60 & - & - & - & - & - & - & - & $\cdot$ & - & $\cdot$ & 1 & 40 & 20 & 10 & 3 \\
\hline 25 & Fraxinus caroliniana & - & 2 & . & - & • & - & - & - & - & - & - & - & - & - & - & - & - & - & - & - \\
\hline 24 & Fraxinus pennsylvanica & 1 & - & - & - & - & - & - & - & - & - & - & - & - & - & - & - & 1 & - & . & - \\
\hline 126 & Hex cassine & - & - & - & 1 & - & - & - & - & - & - & - & - & - & - & - & 0.5 & - & - & - & - \\
\hline 35 & Liquidambar styraciflua & 2 & 1 & 1 & - & - & - & - & - & - & - & - & - & - & - & - & 2 & 10 & - & 2 & - \\
\hline 146 & Magnolia granidflora & - & - & - & - & - & - & - & - & - & - & - & - & - & - & - & - & - & - & - & - \\
\hline
\end{tabular}


TABLE C.2 (Cont.)

\begin{tabular}{|c|c|c|c|c|c|c|c|c|c|c|c|c|c|c|c|c|c|c|c|c|c|}
\hline \multirow{3}{*}{$\begin{array}{l}\text { Field } \\
\text { Number }\end{array}$} & \multirow[b]{3}{*}{ Species Names } & \multicolumn{20}{|c|}{ Areal Cover ${ }^{\mathrm{a}}(\%)$} \\
\hline & & \multicolumn{5}{|c|}{ South Natural Area } & \multicolumn{5}{|c|}{ South ROW Area } & \multicolumn{5}{|c|}{ North ROW Area } & \multicolumn{5}{|c|}{ North Natural Area } \\
\hline & & $\mathrm{T} 1$ & $\mathrm{~T} 2$ & T3 & T4 & T5 & $T 1$ & $\mathrm{~T} 2$ & T3 & $T_{4}$ & T5 & $\mathrm{T} 1$ & $\mathrm{~T} 2$ & T3 & $\mathrm{T} 4$ & T5 & T1 & $\mathrm{T} 2$ & T3 & T4 & T5 \\
\hline 34 & Magnolia virginiana & - & - & $\cdot$ & - & - & - & - & - & $\cdot$ & - & - & - & - & - & - & 2 & - & - & - & - \\
\hline 29 & Nyssa ogeche & 3 & 1 & 1 & - & - & $\cdot$ & - & $\cdot$ & $\cdot$ & - & - & - & - & - & - & 1 & 10 & $\cdot$ & 1 & - \\
\hline 39 & Quercus laurifolia & 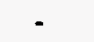 & - & 3 & 15 & - & $\cdot$ & - & $\cdot$ & $\cdot$ & $\cdot$ & - & - & - & - & $\cdot$ & 2 & $\cdot$ & 2 & 1 & 2 \\
\hline 30 & Quercus michauxii & - & - & $\cdot$ & 2 & - & $\cdot$ & - & - & $\cdot$ & - & - & - & - & - & - & - & - & - & - & - \\
\hline 135 & Quercus nigra & - & - & $\cdot$ & 2 & - & - & - & - & - & $\cdot$ & - & - & - & $\cdot$ & $\cdot$ & - & - & $\cdot$ & $\cdot$ & 0.5 \\
\hline \multirow[t]{2}{*}{98} & Taxodium distichum & - & - & 1 & - & $\cdot$ & $\cdot$ & - & $\cdot$ & - & $\cdot$ & - & $\cdot$ & - & - & - & - & - & 2 & - & - \\
\hline & TREESTRATUM & & & & & & & & & & & & & & & & & & & & \\
\hline 19 & Acer rubrum & 458 & 2190 & - & - & - & - & - & - & - & - & - & - & - & - & - & 1894 & 1254 & - & 335 & - \\
\hline 22 & Carpinus caroliniana & 134 & 0.35 & - & - & - & - & - & - & - & - & - & - & - & - & - & - & 204 & - & 134 & - \\
\hline 25 & Fraxinus caroliniana & 458 & - & - & - & $\cdot$ & - & - & - & - & - & - & - & - & - & - & - & - & 385 & - & - \\
\hline 27 & Ilex opaca & - & $\cdot$ & - & $\cdot$ & 156 & - & - & - & - & - & $\cdot$ & - & - & $\cdot$ & $\cdot$ & - & - & - & - & $\cdot$ \\
\hline 35 & Liquidambar styraciflua & 287 & 538 & - & 872 & - & - & - & - & $\cdot$ & - & $\cdot$ & $\cdot$ & - & - & - & 258 & 1447 & - & 2035 & - \\
\hline 34 & Magnolia virginiana & - & - & - & $\cdot$ & $\cdot$ & - & $\cdot$ & - & - & - & - & - & $\cdot$ & $\cdot$ & - & 3119 & - & - & - & - \\
\hline 29 & Nyssa ogeche & 134 & 204 & - & - & $\cdot$ & - & $\cdot$ & - & - & - & - & $\cdot$ & - & $\cdot$ & $\cdot$ & - & 2058 & - & $\cdot$ & 764 \\
\hline 162 & Pinus taeda & - & - & 1089 & 1044 & - & - & - & - & - & - & - & - & - & - & - & - & - & - & - & - \\
\hline 39 & Quercus laurifolia & 1833 & 1273 & 3160 & - & 179 & - & $=$ & - & - & - & - & - & - & - & - & 258 & 764 & 580 & 4156 & 204 \\
\hline 135 & Quercus nigra & - & - & 1400 & 1220 & - & - & - & - & $\cdot$ & - & - & - & - & - & - & - & - & - & - & - \\
\hline \multirow[t]{2}{*}{98} & Taxodium distichum & 5269 & $\cdot$ & 204 & $\cdot$ & $\cdot$ & $\cdot$ & $\cdot$ & - & $\cdot$ & - & - & - & $\cdot$ & - & - & 2731 & $\cdot$ & 3865 & 678 & $\cdot$ \\
\hline & VINE STRATUM & & & & & & & & & & & & & & & & & & & & \\
\hline 128 & Campsis radicans & - & - & 6 & 5 & - & - & - & - & - & - & - & - & - & - & - & - & - & - & 3 & - \\
\hline 31 & Decumaria barbara & 3 & 1 & . & 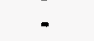 & - & - & - & - & - & - & - & - & $*$ & - & - & - & 3 & - & . & - \\
\hline 118 & Gelsemium sempervirens & 1 & 7 & $\cdot$ & - & $\cdot$ & - & $\cdot$ & $\cdot$ & $\cdot$ & $\cdot$ & $\cdot$ & $\cdot$ & - & - & $\cdot$ & $\therefore$ & 14 & $\cdot$ & $\cdot$ & - \\
\hline 161 & Rhus toxicodendron & - & 1 & - & - & - & - & - & - & - & - & - & $\cdot$ & - & - & $\cdot$ & 5 & 1 & - & - & 5 \\
\hline 145 & Smilax glauca & $\cdot$ & - & 6 & 6 & - & - & - & - & - & $\cdot$ & $\cdot$ & - & - & - & - & - & $\cdot$ & - & - & - \\
\hline 60 & Vitis rotundifolla & - & - & 7 & 1 & $\cdot$ & - & - & - & - & - & - & - & - & - & - & 24 & 1 & - & - & 1 \\
\hline
\end{tabular}

Values are percent areal cover for herb, shrub, and sapling strata; total basal area for trees of that species in the plot; or number of vines per plot. 
TABLE C.3 Average Percent Cover, Absolute Frequencies, and Distribution of Species by Stratum, Deep Creek Site

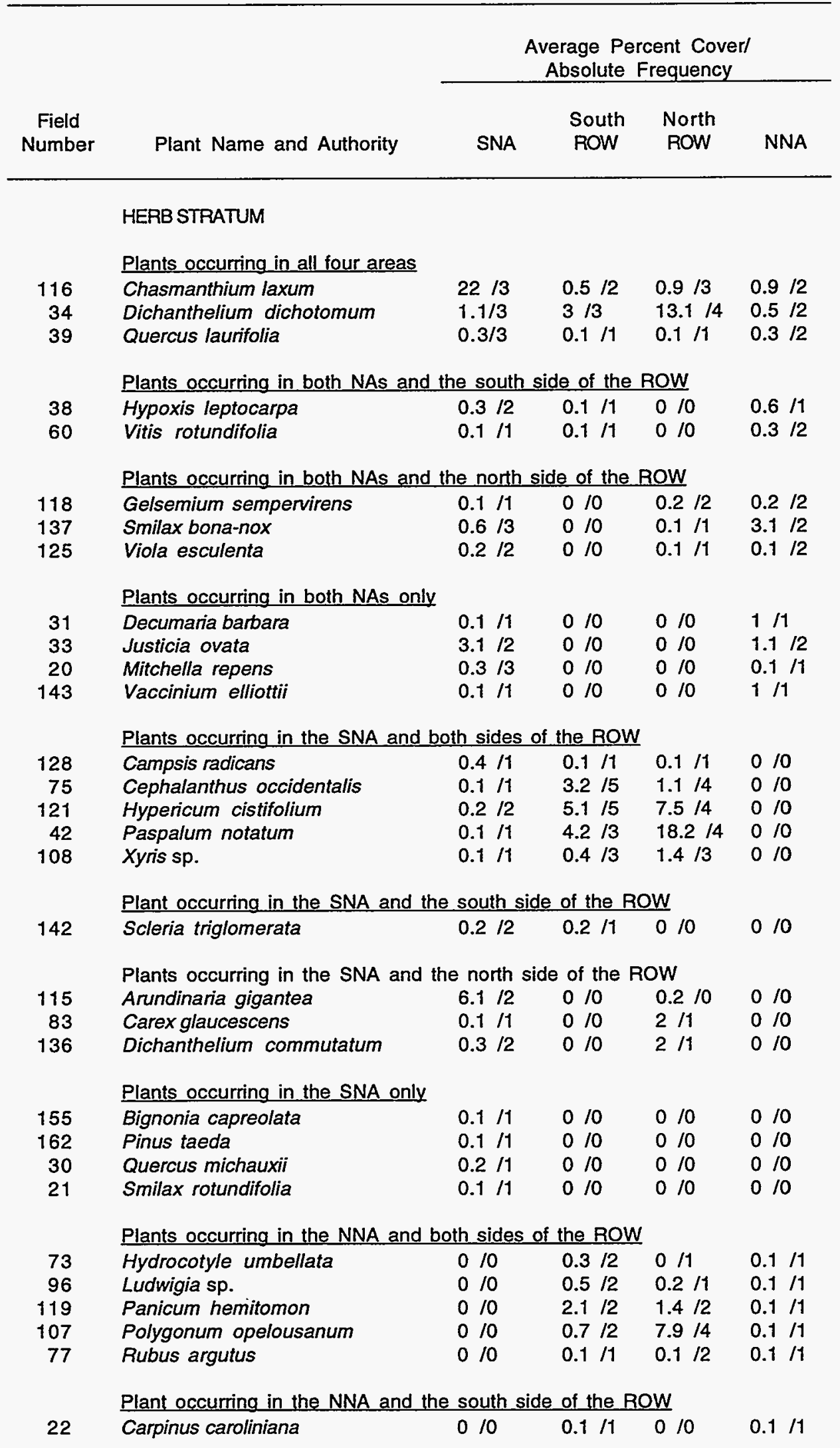




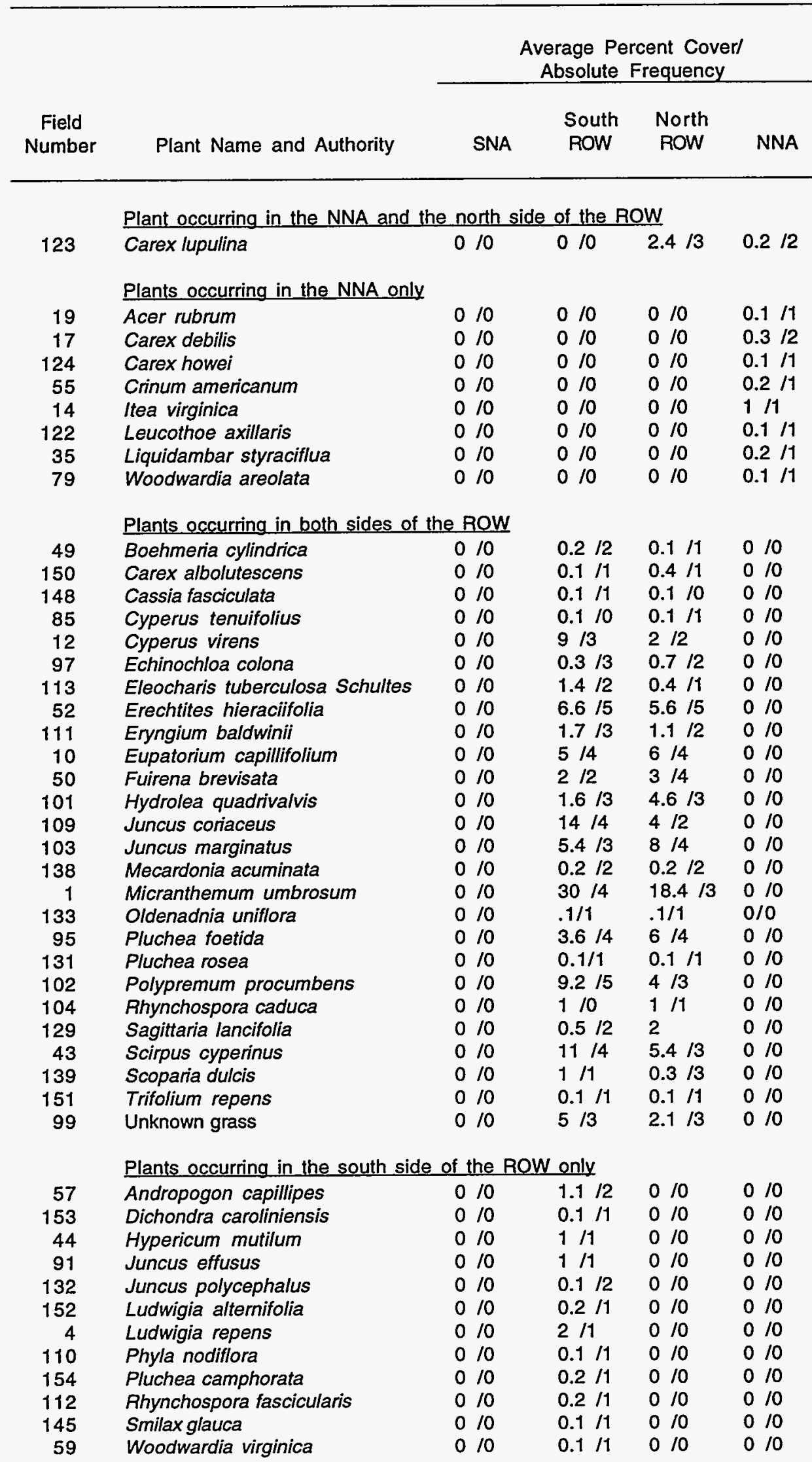


TABLE C.3 (Cont.)

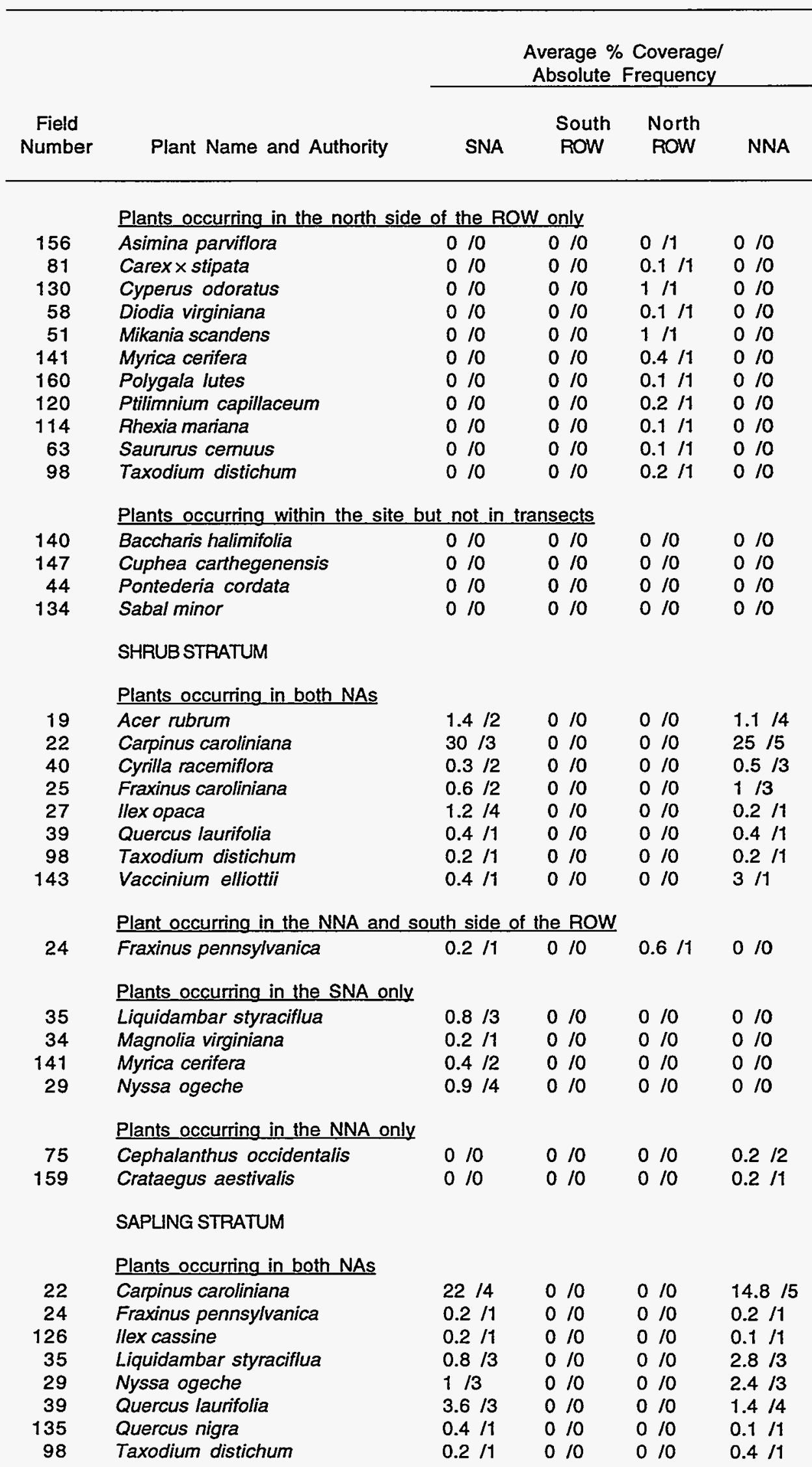




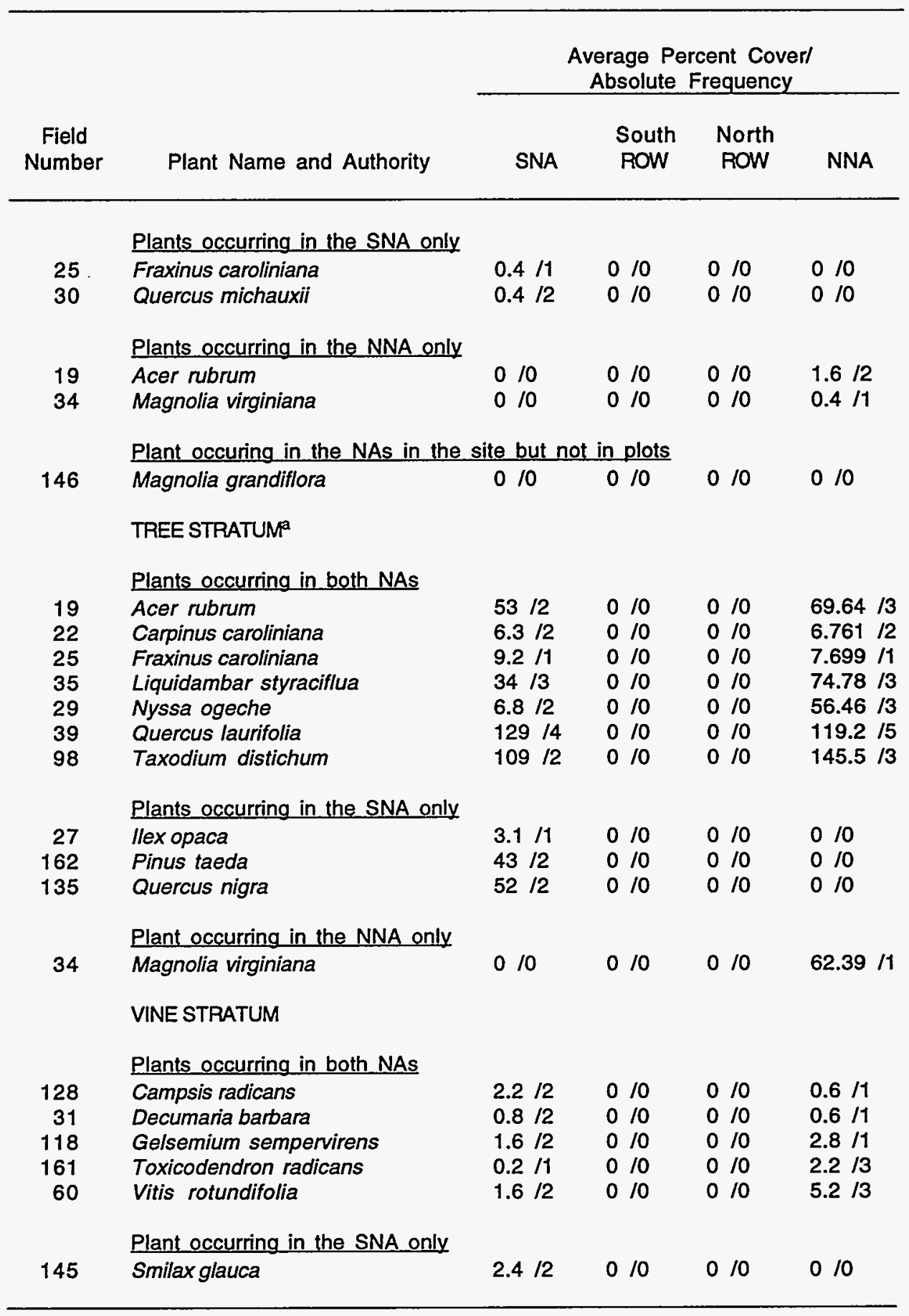

a Numbers for trees indicate average basal area per plot over the number of plots in which they occur. 


\begin{tabular}{|c|c|c|c|c|}
\hline $\begin{array}{c}\text { Field } \\
\text { Number }\end{array}$ & Scientific Name and Authority & Common Name & $\begin{array}{l}\text { Region } 2 \\
\text { Wetland } \\
\text { Indicator } \\
\text { Categories }^{\mathrm{a}}\end{array}$ & $\begin{array}{l}\text { Life- } \\
\text { Form/ } \\
\text { Origin }\end{array}$ \\
\hline 19 & Acer rubrum $L$ & Red Maple & FAC & NT \\
\hline 64 & Alternanthera philoxeroides Griseb. & Alligator Weed & OBL & PIEF \\
\hline 57 & Andropogon capillipes Nash & Chalky Bluestem & FACU & PNG \\
\hline 32 & Asclepias perennis Walter & Aquatic Milkweed & OBL & PNF \\
\hline 49 & Boehmeria cylindrica (L.) Swartz & Small-Spike False-Nettle & FACW+ & PNF \\
\hline 69 & Carex albolutescens Schweinitz & Greenish-White Sedge & $\mathrm{FAC}+$ & PNGL \\
\hline 17 & Carex debilis Michx. & White-Edge Sedge & FACW & PNGL \\
\hline 83 & Carex glaucescens Elliott & Southern Waxy Sedge & OBL & PNEGL \\
\hline 82 & Carex lunida Wahlenb. & Shallow Sedge & OBL & PNEGL \\
\hline 81 & Carex $\times$ stipata Muhl. Ex Willd. & Stalk-Grain Sedge & $\mathrm{OBL}$ & PNGL \\
\hline 22 & Carpinus caroliniana Walter & American Hornbeam & FAC & NT \\
\hline 61 & Centella asiatica (L.) Urban & Asian Coinleaf & FACW & PNF \\
\hline 75 & Cephalanthus occidentalis $L$. & Common Buttonbush & OBL & NT \\
\hline 94 & Chasmanthium laxum (L.) $H$. Yates & Slender Spikegrass & FACW- & PNG \\
\hline 3 & Commelina diffusa N.L. Burm. & Spreading Dayflower & FACW & AlF \\
\hline 55 & Crinum americanum $L$. & Southern Swamplily & $\mathrm{OBL}$ & PNF \\
\hline 7 & Cyperus distinctus Steud. & Marshland Flatsedge & FACW & PNGL \\
\hline 85 & Cyperus tenuifolius (Steud.) Dandy & Thin-Leaf Flatsedge & FACW & ANGL \\
\hline 12 & Cyperus virens Michx. & Green Flatsedge & FACW & PNEGL \\
\hline 40 & Cyrilla racemiflora $L$. & Swamp Cyrilla & FACW & NT \\
\hline 31 & Decumaria barbara $L$ & Southeast Decumaria & FACW & NWV \\
\hline 11 & Dichanthelium dicotomum (L.) Gould & Cypress Witchgrass & FAC & PNG \\
\hline 65 & Digitaria serotina (Walter) Michx. & Dwarf Crabgrass & FAC & ANG \\
\hline 58 & Diodia virginiana $L$. & Virginia Button-Weed & FACW & APNEF \\
\hline 71 & Echinochloa walteri (Pursh) A. Heller & Coast Cockspur & OBL & ANEG \\
\hline 92 & Eichhornia crassipes (Mart.) Solms. & Common Water-Hyacinth & OBL & PNE/F \\
\hline 46 & Eleocharis microcarpa Torr. & Small-Fruit Spikerush & OBL & ANEGL \\
\hline 45 & $\begin{array}{l}\text { Eleocharis tuberculosa (Michx.) Roem. \& } \\
\text { J.A. Schultes }\end{array}$ & Long-Tubercle Spikerush & FACW+ & PNGL \\
\hline 52 & Erechtites hieraciifolia (L.) Raf. Ex Dc. & American Bum & FAC- & ANF \\
\hline 87 & Erigeron vernus (L.) Torr. \& Gray & Early Whitetop Fleabane & OBL & PNF \\
\hline 10 & Eupatorium capillifolium (Lam.) Small & $\begin{array}{l}\text { Small Dog-Fennel } \\
\text { Thorough-Wort }\end{array}$ & FAOU & PNF \\
\hline 66 & $\begin{array}{l}\text { Fimbristylis autumnalis (L.) Roem. \& J.A. } \\
\text { Schultes }\end{array}$ & Slender Fimbry & OBL & $G$ \\
\hline 25 & Fraxinus caroliniana Mill. & Carolina Ash & OBL & NETS \\
\hline 24 & Fraxinus pennsylvanica Marshall & Green Ash & FACW & NT \\
\hline 68 & Fuirena breviseta Coville & Saltmarsh Umbrella-Sedge & OBL & PNGL \\
\hline 5 & Gratiola virginana $L$. & Round-Fruit Hedgehyssop & $\mathrm{OBL}$ & ABNEF \\
\hline 73 & Hydrocotyle umbellata $L$. & Many-Flower Penny-Wort & OBL & PN/F \\
\hline 44 & Hypericum mutilum $L$. & Slender St. John's-Wort & FACW & PNF \\
\hline 38 & $\begin{array}{l}\text { Hypoxis leptocarpa (Engelm. \& Gray) Engelm. } \\
\text { \& Gray ex Small }\end{array}$ & Clubpod Goldstar & FACW & PNEF \\
\hline 27 & Ilex opaca Soland In Ait. & American Holly & FAC & NTS \\
\hline 6 & Iris hexagona Walter & Prairie Iris & OBL & PNF \\
\hline 14 & Itea virginica $L$. & Virginia Willow & FACW+ & NS \\
\hline 91 & Juncus effusus $L$ & Soft Rush & FACW+ & PNEGL \\
\hline 84 & Juncus polycephalus Michx. & Many-Head Rush & OBL & PNGL \\
\hline 47 & Juncus repens Michx. & Creeping Rush & OBL & PNGL \\
\hline 33 & Justicia ovata (Walter) Lindau & Loose-Flower Water-Willow & OBL & PNF \\
\hline 26 & Leucothoe racemosa (L.) Gray & Fetter-Bush & FACW & NS \\
\hline 35 & Liquidambar styraciflua $L$ & Sweet Gum & $\mathrm{FAC+}$ & NT \\
\hline 13 & Ludwigia glandulosa Walter & Cylindric-Fruit Seedbox & OBL & PNEF \\
\hline 4 & Ludwigia repens J. Forst. & Creeping Sandbox & $\mathrm{OBL}$ & PNEF \\
\hline
\end{tabular}


TABLE C.4 (Cont.)

\begin{tabular}{|c|c|c|c|c|}
\hline $\begin{array}{l}\text { Field } \\
\text { Number }\end{array}$ & Scientific Name and Authority & Common Name & $\begin{array}{l}\text { Region } 2 \\
\text { Wetland } \\
\text { Indicator } \\
\text { Categories }^{a}\end{array}$ & $\begin{array}{l}\text { Life- } \\
\text { Form/ } \\
\text { Origin }^{b}\end{array}$ \\
\hline 88 & Ludwigia sp. & & & \\
\hline 16 & Lyonia lucida (Lam.) K. Koch & Fetter-Bush & FACW & NS \\
\hline 34 & Magnolia virginiana $L$. & Sweetbay Magnolia & FACW+ & NT \\
\hline 1 & Micranthemum umbrosum (Walter) Blake & Shade Mudflower & OBL & PFF \\
\hline 51 & Mikania scandens (L.) Willd. & Climbing Hempweed & $\mathrm{FACW}_{+}$ & PNV \\
\hline 20 & Mitchella repens $L$. & Partridge-Berry & FACUt & PNF \\
\hline 28 & Myrica cerifera $L$. & Southern Bayberry & FAC+ & NST \\
\hline 53 & Myriophyllum brasiliense Cambees. & Parrot-Feather & OBL & PNZF \\
\hline 93 & Nyssa ogeche W. Bartram Ex Marshall & Ogeechee Tupelo & OBL & NT \\
\hline 89 & Panicum hemitomon J.A. Schultes & Maiden-Cane & OBL & PNEG \\
\hline 72 & Panicum maximum Jacq. & Guinea Grass & FAC & PIG \\
\hline 42 & Paspalum notatum Fluegge & Bahia Grass & FACU+ & PIG \\
\hline 62 & Persea borbonia (L.) Spreng. & Red Bay & FACW & NT \\
\hline 74 & Pinus glabra Walter & Spruce Pine & FACW & NT \\
\hline 67 & Pluchea camphorata (L.) DC. & Salt Marsh Camphor-Weed & FACW & APIF \\
\hline 2 & Polygonum punctatum Elloitt & Dotted Smartweed & $\mathrm{FACW}_{+}$ & PNEF \\
\hline 36 & Polygonum setaceum Baldw. & Swamp Smartweed & FACW & PNEF \\
\hline 41 & Pontederia cordata $L$. & Pickerel Weed & OBL & PNEF \\
\hline 39 & Quercus laurifolia Michx. & Laurel Oak & FACW & NT \\
\hline 30 & Quercus michauxii Nutt. & Swamp Chestnut Oak & FACW- & NT \\
\hline 18 & Rhododendron canescens (Michx.) Sweet & Hoary Azalea & FACW- & NS \\
\hline 70 & Rhynchospora microcephala (Britton) Britton & Capitate Beakrush & OBL & GL \\
\hline 77 & Rubus argutus Link & Serrate-Leaf Blackberry & FACUt & NS \\
\hline 48 & Salix nigra Marshall & Black Willow & OBL & NT \\
\hline 63 & Saururus cermuus $L$. & Lizard's Tail & OBL & PNEF \\
\hline 43 & Scirpus cyperinus (L.) Kunth & Wool-Grass & OBL & PNEGL \\
\hline 15 & Smilax laurifolia $L$. & Laurel-Leaf Greenbrier & FACW+ & NWV \\
\hline 21 & Smilax rotundifolia $L$. & Common Greenbrier & FAC & NWV \\
\hline 37 & Smilax smallii Morong & Lance-Leaf Greenbrier & FACU & NWV \\
\hline 98 & Taxodium distichum (L.) L.C. Rich. & Bald Cypress & OBL & NET \\
\hline 161 & Toxicodendron radicans (L.) Kuntze & Poison Ivy & FAC & NWVS \\
\hline 76 & Triadenum walteri (J.F. Gmel.) Gleason & $\begin{array}{l}\text { Larger Marsh } \\
\text { St.John's-Wort }\end{array}$ & OBL & PNEF \\
\hline 9 & Typha latifolia $L$. & Broad-Leaf Cattail & OBL & PNEF \\
\hline 163 & Ulmus americana $L$. & American Elm & FACW & NT \\
\hline 54 & Vaccinium arboreum Marshall & Farkleberry & FACU & NST \\
\hline 56 & Vaccinium fuscatum Ait. & Fuscous Blueberry & FACt & NS \\
\hline 60 & Vitis rotundifolia Michx. & Muscadine Grape & FAC & NWV \\
\hline 79 & Woodwardia areolata (L.) T. Moore & Netted Chainfern & OBL & PNEF3 \\
\hline 59 & Woodwardia virginica (L.) J.E. Smith & Virginia Chainfern & OBL & PNF3 \\
\hline 90 & Xyris jupica L.C. Rich. & Richard's Yellow-Eyed Grass & OBL & APNEF \\
\hline
\end{tabular}

a Wetland indicator categories are assigned to plants in the United States on a regional basis. Florida is located in Region 2. A ' + ' following an indicator indicates a frequency toward the high end of the category (more frequently found in wetlands), while a '-' indicates a frequency toward the low end (less frequently found in wetlands).

b Plant characteristics and life-forms assigned to species in Reed (1988). 
TABLE C.5 Cover Estimates for Each Species by Stratum, Brandy Branch Site

\begin{tabular}{|c|c|c|c|c|c|c|c|c|c|c|c|c|c|c|c|c|c|c|c|c|c|}
\hline \multirow{3}{*}{$\begin{array}{l}\text { Field } \\
\text { Number }\end{array}$} & \multirow{3}{*}{$\begin{array}{l}\text { Species Name and } \\
\text { Authority }\end{array}$} & \multicolumn{20}{|c|}{ Areal Cover $(\%)$} \\
\hline & & \multicolumn{5}{|c|}{ West Natural Area } & \multicolumn{5}{|c|}{ West ROW Area } & \multicolumn{5}{|c|}{ East ROW Area } & \multicolumn{5}{|c|}{ East Natural Area } \\
\hline & & $T 1$ & $\mathrm{~T} 2$ & T3 & T4 & T5 & T1 & T2 & T3 & $T_{4}$ & T5 & T1 & T2 & T3 & $\mathrm{T}_{4}$ & T5 & T1 & $\mathrm{T} 2$ & T3 & T4 & T5 \\
\hline & Exposed soll & - & - & - & - & - & 10 & 13 & 30 & 20 & 20 & 10 & 13 & 10 & 10 & 10 & - & - & - & - & - \\
\hline & HERB STRATUM & & & & & & & & & & & & & & & & & & & & \\
\hline 19 & Acer rubrum & 0.5 & 0.5 & - & - & . & - & . & - & - & - & - & 0.5 & - & . & - & 0.5 & - & 5 & - & 0.55 \\
\hline 64 & Alternanthera phlloxeroldes & $\therefore$ & - & 1 & 1 & - & - & - & 30 & - & 5 & - & - & 5 & - & - &. & - & - & - & - \\
\hline 57 & Andropogon capillipes & - & - & - & : & - & - & $\cdot$ & - & - & - & - & - & - & - & - & - & 0.5 & - & - & - \\
\hline 32 & Asclepias perennis & - & - & - & - & - & - & - & - & - & - & - & - & - & - & - & - & - & $\cdot$ & - & - \\
\hline 49 & Boohmeria cylindrica & - & - & - & 0.5 & - & - & - & - & - & - & . & 0.5 & - & - & - & - & 0.5 & 10 & - & - \\
\hline 69 & Carex albolutescons & - & - & - & - & - & - & - & - & - & - & - & $\cdot$ & - & 7 & - & - & $\cdot$ & - & - & - \\
\hline 17 & Carox debills & - & - & - & - & - & - & - & - & . & - & . & - & . & . & - & - & - & - & - & - \\
\hline 83 & Carex glaucescens & - & - & - & - & - & - & . & - & - & - & - & - & - & - & - & - & - & - & 0.5 & . \\
\hline 82 & Carex Iurida & - & - & - & - & - & - & - & - & - & - & - & - & - & - & - & . & - & - & - & - \\
\hline 81 & Carex $\cdot$ stipata & - & - & - & - & - & - & - & . & - & - & - & - & - & . & - & - & - & - & - & - \\
\hline 22 & Carpinus caroliniana & - & - & - & 0.5 & 0.5 & - & . & - & - & - & - & - & - & . & - & - & 0.5 & 1 & . & - \\
\hline 61 & Contella asiatica & . & - & - & $\cdot$ & $\cdot$ & - & - & - & - & - & - & - & - & - & - & - &. & . & - & - \\
\hline 75 & Cephalanthus occidentalis & - & - & - & - & - & - & - & - & - & - & - & - & - & - & - & . & - & 0.5 & - & - \\
\hline 94 & Chasmanthium laxum & - & - & - & - & - & - & - & - & - & - & . & - & - & - & . & - & . &. & - & - \\
\hline 3 & Commellna diffusa & - & - & - & - & - & - & - & 5 & - & - & 5 & - & . & . & - & - & . & - & - & 1 \\
\hline 55 & Crinum americanum & - & 5 & - & - & - & - & - & - & - & - & - & - & - & - & - & - & - & - & - & - \\
\hline 7 & Cyperus dlstinctus & - & - & - & - & - & 10 & - & - & - & - & 1 & 1 & - & . & 8 & . & - & - & . & - \\
\hline 85 & Cyperus tenuifollus & - & - & - & - & - & - & - & - & - & . & : & . & - & 1 & - & . & - & - & - & - \\
\hline 12 & Cyperus virens & - & - & - & - & 5 & - & - & - & 2 & 5 & - & 25 & 12 & . & 5 & $\cdot$ & 1 & 0.5 & - & - \\
\hline 31 & Decumaria barbara & - & - & - & - & - & - & . & - & $=$ & - & - & 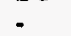 & - & - & . & 0.5 & - & - & 0.5 & - \\
\hline 11 & Dichanthellum dicotomum & - & 0.5 & - & - & - & 2 & - & - & 1 & - & - & - & - & - & . &. & - & 5 & 0.5 & - \\
\hline 65 & Digitaria serotina & - & - & - & - & - & $=$ & - & - & $:$ & - & - & - & 2 & - & - & - & - & 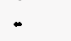 & - & - \\
\hline 58 & Diodia virginlana & - & - & - & - & - & - & - & - & - & - & - & - & - & - & - & - & 8 & - & - & - \\
\hline 71 & Echinochloa walteri & - & - & . & - & - & - & - & . & 0.5 & . & - & - & 0.5 & 15 & . & - & . & - & - & - \\
\hline 92 & Eichhornia crassipes & - & - & - & - & - & - & . & - & . & - & - & . & 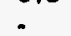 & . & . & - & . & - & . & - \\
\hline 46 & Eleocharis microcarpa & - & - & - & - & - & - & . & - & - & - & - & 0.5 & . & - & - & . & - & - & - & - \\
\hline 45 & Eleocharis tuberculosa & - & - & - & - & - & . & - & - & - & - & - & 7 & - & - & - & . & . & - & - & - \\
\hline 52 & Erechtites hieracilfolia & - & - & - & - & - & - & - & - & - & - & - & 0.5 & 0.5 & - & 0.5 & - & 1 & 0.5 & - & 1 \\
\hline 87 & Erigeron vermus & $\cdot$ & - & - & - & - & $\cdot$ & - & - & - & - & - &. & - & - & - & - & $\cdot$ & 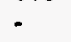 & - & - \\
\hline 10 & Eupatorium capillifollum & 0.5 & . & - & - & - & 0.5 & - & - & 0.5 & - & - & 0.5 & 0.5 & 0.5 & $\cdot$ & - & 1 & - & - & - \\
\hline 66 & Fimbristylis autumnalis & - & - & . & - & - &. & . & - & 1 & - & - &. & 15 & 2 & 0.5 & - & . & - & - & . \\
\hline 24 & Fraxinus pennsylvanica & 0.5 & - & - & - & - & - & . & - & - & . & - & - & - & $=$ & 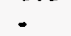 & - & - & - & - & - \\
\hline 50 & Fuirena breviseta & - & - & . & - & - & - & . & - & . & - & - & 3 & 25 & . & - & - & - & - & . & . \\
\hline 5 & Gratiola virginana & - & - & 3 & - & - & 10 & 5 & 3 & 2 & 0.5 & 5 & 5 & 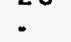 & 1 & 2 & 0.5 & - & - & - & - \\
\hline 73 & Hydrocotylo umbellata & - & . & - & . & - &. & . & - & - & . & . & . & - & $\therefore$ & : & . & - & - & - & 0.5 \\
\hline 44 & Hypericum mutilum & $\cdot$ & - & - & 0.5 & - & - & . & - & 1 & - & - & 0.5 & 3 & - & - & - & - & - & . &. \\
\hline 38 & Hypoxis loptocarpa & 0.5 & - & - & 1 & - & - & - & - & $\therefore$ & - & - & - & - & - & - & - & 0.5 & - & - & - \\
\hline
\end{tabular}




\begin{tabular}{|c|c|c|c|c|c|c|c|c|c|c|c|c|c|c|c|c|c|c|c|c|c|}
\hline \multirow{3}{*}{$\begin{array}{l}\text { Field } \\
\text { Number }\end{array}$} & \multirow{3}{*}{$\begin{array}{l}\text { Species Name and } \\
\text { Authority }\end{array}$} & \multicolumn{20}{|c|}{ Areal Cover ${ }^{\mathrm{a}}(\%)$} \\
\hline & & \multicolumn{5}{|c|}{ West Natural Area } & \multicolumn{5}{|c|}{ West RoW Area } & \multicolumn{5}{|c|}{ East ROW Area } & \multicolumn{5}{|c|}{ East Natural Area } \\
\hline & & $\mathrm{T} 1$ & $\mathrm{~T} 2$ & T3 & T4 & T5 & $\mathrm{T} 1$ & T2 & T3 & T4 & T5 & T1 & T2 & T3 & T4 & T5 & T1 & $\mathrm{T} 2$ & T3 & T4 & T5 \\
\hline 27 & Ilex opaca & 0.5 & $\cdot$ & $\cdot$ & - & - & - & $\cdot$ & - & - & - & - & - & - & - & - & - & - & 0.5 & - & - \\
\hline 6 & Iris hexagona & - & - & $\cdot$ & $\cdot$ & - & - & - & - & $\cdot$ & - & 0.5 & $\cdot$ & - & $\cdot$ & $\cdot$ & - & $\cdot$ & $\cdot$ & $\cdot$ & $\cdot$ \\
\hline 14 & Itea virginica & - & - & - & - & 0.5 & - & - & - & $\cdot$ & - & - & $\cdot$ & - & - & $\cdot$ & 2 & $\cdot$ & - & $\cdot$ & $\cdot$ \\
\hline 91 & Juncus effusus & - & - & $\cdot$ & - & $\cdot$ & - & - & - & $\cdot$ & - & - & $\cdot$ & $\cdot$ & - & $\cdot$ & - & $\cdot$ & $\cdot$ & - & $\cdot$ \\
\hline 84 & Juncus polycephalus & $\cdot$ & - & $\cdot$ & $\cdot$ & $\cdot$ & - & $\cdot$ & - & $\cdot$ & - & - & $\cdot$ & - & $\cdot$ & $\cdot$ & $\cdot$ & $\cdot$ & * & $\cdot$ & $\cdot$ \\
\hline 47 & Juncus repens & - & - & $\cdot$ & - & $\cdot$ & $\cdot$ & $\cdot$ & $\cdot$ & - & $\cdot$ & - & 1 & - & - & - & - & - & - & - & - \\
\hline 33 & Justicia ovata & 75 & 2 & - & 1 & 15 & - & - & - & - & $\cdot$ & - & 1 & - & 0.5 & - & $\cdot$ & - & 5 & 10 & 1 \\
\hline 35 & Liquidambar styraciflua & 0.5 & - & - & 0.5 & - & - & - & $\cdot$ & $\cdot$ & - & - & $\cdot$ & $\cdot$ & - & - & - & 0.5 & - & - & $\cdot$ \\
\hline 13 & Ludwigia glandulosa & $\cdot$ & - & - & $\cdot$ & $\cdot$ & $\cdot$ & - & $\cdot$ & $\cdot$ & - & - & - & - & 0.5 & - & - & - & 2 & - & 0.5 \\
\hline 4 & Ludwigla repens & 0.5 & 3 & 5 & 5 & - & 15 & 8 & 5 & 50 & 8 & 20 & 0.5 & 10 & 50 & 25 & - & 8 & 5 & 1 & $\cdot$ \\
\hline 88 & Ludwigia sp. & $\cdot$ & $\cdot$ & - & - & $\cdot$ & - & $\cdot$ & $\cdot$ & $\cdot$ & $\cdot$ & - & $\cdot$ & $\cdot$ & $\cdot$ & 0.5 & - & - & - & $\cdot$ & $\cdot$ \\
\hline 16 & Lyonia lucida & 0.5 & 3 & - & 2 & - & - & - & - & - & - & - & - & - & - & - & 10 & 0.5 & - & - & - \\
\hline 34 & Magnolla virginlana & 10 & - & - & - & - & - & - & $\cdot$ & - & - & - & - & - & - & - & - & - & - & - & - \\
\hline 1 & Micranthemum umbrosum & 25 & 50 & 20 & 8 & 10 & 50 & 50 & 20 & 60 & 20 & 50 & 75 & 50 & 40 & 80 & 2 & $\cdot$ & - & 1 & 20 \\
\hline 51 & Mikanla scandens & $\cdot$ & $\cdot$ & - & - & $\cdot$ & $\cdot$ & $\cdot$ & $\cdot$ & $\cdot$ & $\cdot$ & - & 0.5 & $\cdot$ & - & - & - & - & - & - & - \\
\hline 20 & Mitchella repens & - & - & - & - & $\cdot$ & $\cdot$ & - & $\cdot$ & - & $\cdot$ & - & - & - & - & - & 0.5 & - & - & - & 0.5 \\
\hline 53 & Myriophyllum brasilionse & - & - & - & - & - & $\cdot$ & 10 & & - & $\cdot$ & - & - & $\cdot$ & $\cdot$ & - & $\cdot$ & - & $\cdot$ & - & - \\
\hline 93 & Nyssa ogeche & - & - & - & - & $\cdot$ & $\cdot$ & - & - & - & $\cdot$ & $\cdot$ & - & - & $\cdot$ & - & - & - & - & - & - \\
\hline 89 & Panicum hemitomon & $\cdot$ & $\cdot$ & - & - & - & - & - & $\cdot$ & - & - & - & - & - & - & 2 & - & - & - & - & - \\
\hline 72 & Panicum maximum & - & - & 5 & - & - & - & $\cdot$ & $\cdot$ & - & - & - & - & $\cdot$ & - & $\cdot$ & - & $\cdot$ & - & - & - \\
\hline 42 & Paspalum notatum & - & - & - & - & - & - & - & - & - & - & - & 40 & $\cdot$ & - & - & $\cdot$ & - & - & - & - \\
\hline 67 & Pluchea camphorata & - & - & - & - & $\cdot$ & - & - & - & 0.5 & - & - & - & 0.5 & 0.5 & - & - & - & $\cdot$ & - & - \\
\hline 2 & Polygonum punctatum & 5 & - & 0.5 & 3 & 0.5 & 10 & $\cdot$ & 0.5 & 0.5 & - & 10 & - & - & 0.5 & - & 1 & - & 0.5 & 2 & - \\
\hline 36 & Polygonum setaceum & 0.5 & $\cdot$ & $\cdot$ & - & - & - & - & - & $\cdot$ & $\cdot$ & $\cdot$ & - & - & $\cdot$ & - & - & $\cdot$ & $\cdot$ & - & $\cdot$ \\
\hline 41 & Pontederla cordata & $\dot{-}$ & - & - & - & - & $\cdot$ & - & - & - & 5 & $\cdot$ & $\cdot$ & - & $\cdot$ & - & - & $\cdot$ & - & - & - \\
\hline 39 & Quercus laurifolla & 0.5 & 0.5 & 0.5 & - & 0.5 & - & $\cdot$ & - & - & $\cdot$ & - & - & - & - & - & - & 0.5 & - & - & - \\
\hline 18 & Rhododendron canescens & - & 0.5 & 0.5 & - & $\cdot$ & - & - & 0.5 & - & - & $\cdot$ & $\cdot$ & - & - & $\cdot$ & 1 & $\cdot$ & $\cdot$ & $\cdot$ & 4 \\
\hline 70 & Ahynchospora microcephala & - & - & $\cdot$ & - & $\cdot$ & - & - & $\cdot$ & $\cdot$ & - & - & - & 8 & $\cdot$ & - & $\cdot$ & $\cdot$ & - & $\cdot$ & - \\
\hline 77 & Rubus argutus & - & - & $\cdot$ & $\cdot$ & $\cdot$ & - & - & - & $\cdot$ & - & - & - & - & $\cdot$ & - & - & - & 2 & - & - \\
\hline 48 & Sallx nigra & - & - & - & - & - & - & - & - & - & - & - & 0.5 & - & 0.5 & - & - & $\cdot$ & - & - & - \\
\hline 63 & Saururus cermuus & - & - & - & - & - & - & - & - & - & - & - & - & - & - & - & - & - & - & - & - \\
\hline 43 & Scirpus cyperinus & - & - & - & - & - & - & - & - & - & - & - & 1 & - & - & - & - & - & - & - & - \\
\hline 15 & Smilax laurifolla & - & - & $\cdot$ & $\cdot$ & - & - & - & - & $\cdot$ & $\cdot$ & - & $\cdot$ & - & $\cdot$ & - & 3 & $\cdot$ & $\cdot$ & $\cdot$ & - \\
\hline 21 & Smilax rotundifolla & 0.5 & - & - & 0.5 & - & - & - & - & * & - & - & - & - & - & $\cdot$ & 0.5 & - & - & $\cdot$ & $\cdot$ \\
\hline 37 & Smilax smallII & 5 & - & - & - & - & - & - & $\cdot$ & - & - & - & - & - & $\cdot$ & - & $\cdot$ & $\cdot$ & - & $\cdot$ & $\cdot$ \\
\hline 161 & Toxicodendron radicans & - & 0.5 & - & - & - & - & - & - & - & - & - & - & - & - & - & - & - & - & - & - \\
\hline 76 & Triadenum walteri Gleason & - & $\cdot$ & - & - & - & - & - & - & - & - & $\cdot$ & $\cdot$ & $\cdot$ & $\cdot$ & - & $\cdot$ & - & 0.5 & $\cdot$ & $\cdot$ \\
\hline 9 & Typha latifolla & - & - & - & - & - & - & - & - & 0.5 & - & 0.5 & 0.5 & - & - & - & - & - & - & - & - \\
\hline 54 & Vaccinium arboreum & - & 0.5 & - & - & $\cdot$ & - & - & $\cdot$ & $\cdot$ & $\cdot$ & $\cdot$ & - & $\cdot$ & $\cdot$ & - & $\cdot$ & - & - & $\cdot$ & - \\
\hline 56 & Vaccinium fuscatum & - & - & - & - & - & - & - & - & - & - & - & - & - & - & - & - & 10 & - & - & - \\
\hline 60 & Vitis rotundifolia & $\cdot$ & $\cdot$ & $\cdot$ & $\cdot$ & $\cdot$ & - & $\cdot$ & $\cdot$ & - & - & - & - & $\cdot$ & $\cdot$ & - & $\cdot$ & $\cdot$ & 0.5 & $\cdot$ & $\cdot$ \\
\hline
\end{tabular}




\begin{tabular}{|c|c|c|c|c|c|c|c|c|c|c|c|c|c|c|c|c|c|c|c|c|c|}
\hline \multirow{3}{*}{$\begin{array}{l}\text { Field } \\
\text { Number }\end{array}$} & \multirow{3}{*}{$\begin{array}{l}\text { Species Name and } \\
\text { Authority }\end{array}$} & \multicolumn{20}{|c|}{ Areal Cover $r^{a}(\%)$} \\
\hline & & \multicolumn{5}{|c|}{ West Natural Area } & \multicolumn{5}{|c|}{ West ROW Area } & \multicolumn{5}{|c|}{ East ROW Area } & \multicolumn{5}{|c|}{ East Natural Area } \\
\hline & & T1 & $\mathrm{T} 2$ & T3 & $\mathrm{T} 4$ & T5 & $\mathrm{T1}$ & T2 & T3 & T4 & T5 & T1 & $\mathrm{T} 2$ & T3 & $\mathrm{T} 4$ & T5 & T1 & $\mathrm{T} 2$ & T3 & $T_{4}$ & T5 \\
\hline 79 & Woodwardla areolata & - & - & - & - & - & - & - & - & - & - & - & - & - & . & - & - & - & - & - & - \\
\hline 59 & Woodwardla virginica & - & - & - & - & - & - & - & - & - & - & - & $\cdot$ & - & - & - & - & 0.5 & - & - & - \\
\hline \multirow[t]{2}{*}{90} & Xyris Juplcal & $\cdot$ & $\cdot$ & $\cdot$ & $\cdot$ & $\cdot$ & $\cdot$ & $\cdot$ & - & $\cdot$ & - & - & $\cdot$ & $\cdot$ & $\cdot$ & - & $\cdot$ & - & $\cdot$ & - & $\cdot$ \\
\hline & SHRUBSTRATUM & & & & & & & & & & & & & & & & & & & & \\
\hline 19 & Acer rubrum & - & - & 1 & - & - & - & - & - & - & - & - & . & - & - & - & - & 1 & - & - & - \\
\hline 22 & Carpinus caroliniana & 1 & 10 & 1 & 3 & 3 & - & - & - & $\cdot$ & - & - & $\cdot$ & - & $\cdot$ & - & 5 & 8 & 40 & 1 & 3 \\
\hline 40 & Cyrilla racemiflora & 1 & - & 1 & - & 2 & - & - & - & - & - & - & - & - & - & - & - & - & $\cdot$ & 3 & 2 \\
\hline 25 & Fraxinus carolliniana & 5 & 1 & - & 3 & 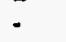 & - & - & - & - & $\cdot$ & - & - & - & - & - & 5 & - & - & - & 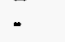 \\
\hline 24 & Fraxinus pennsylvanica & 8 & - & - & - & 10 & - & - & - & - & $\cdot$ & - & - & - & $\cdot$ & - & 2 & - & 1 & - & 0.5 \\
\hline 27 & Hex ораса & - & 4 & - & - & - & $\cdot$ & - & $\cdot$ & $\cdot$ & - & - & - & - & - & - & 3 & $\cdot$ & - & 0.5 & 0.5 \\
\hline 14 & Itea virginica & - & - & $\cdot$ & - & $\cdot$ & $\cdot$ & - & - & - & - & - & - & - & - & - & - & - & - & - & - \\
\hline 26 & Leucothoo racemosa & - & - & 0.5 & - & - & - & $\cdot$ & - & - & - & - & - & * & - & $\cdot$ & 1 & $\cdot$ & - & - & - \\
\hline 35 & Liquidambar styraciflua & 0.5 & - & - & - & 1 & - & - & - & - & - & - & - & - & - & $\cdot$ & - & 5 & $\cdot$ & 3 & - \\
\hline 16 & Lyonia lucida & - & 1 & - & - & - & - & - & - & - & - & - & - & - & - & - & 3 & - & $\cdot$ & 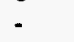 & - \\
\hline 34 & Magnolia virginiana & 2 & $\cdot$ & - & 1 & - & - & - & - & - & - & - & - & - & - & - & - & - & 1 & 2 & - \\
\hline 28 & Myrica cerifora & - & $\cdot$ & - & - & - & - & $\cdot$ & $\cdot$ & - & $\cdot$ & $\cdot$ & - & - & - & . & 1 & - & - & $\cdot$ & - \\
\hline 29 & Nyssa ogeche & - & - & 2 & 1 & 2 & - & - & - & - & - & - & - & $\cdot$ & - & - & $\cdot$ & $\cdot$ & - & - & 1 \\
\hline 30 & Quercus michauxil & - & - & . & - & - & - & - & - & - & - & - & - & $\cdot$ & - & - & 0.5 & 0.5 & - & $\cdot$ & $\cdot$ \\
\hline 18 & Rhododendron canescens & - & $\cdot$ & . & 1 & - & - & - & - & $\cdot$ & $\cdot$ & $\cdot$ & - & $\cdot$ & - & - & - & $\cdot$ & $\cdot$ & $\cdot$ & - \\
\hline \multirow[t]{2}{*}{56} & Vaccinium fuscatum & $\cdot$ & 0.5 & $\cdot$ & - & - & $\cdot$ & $\cdot$ & $\cdot$ & $\cdot$ & - & $\cdot$ & $\cdot$ & $\cdot$ & $\cdot$ & $\cdot$ & - & 0.5 & $\cdot$ & $\cdot$ & $\cdot$ \\
\hline & SAPLNG STRATUM & & & & & & & & & & & & & & & & & & & & \\
\hline 19 & Acer rubrum & - & 1 & - & 1 & - & - & - & - & - & - & - & - & - & - & - & - & - & 4 & - & - \\
\hline 22 & Carpinus caroliniana & - & : & - & - & 2 & - & . & - & - & - & - & - & - & - & - & - & - & - & $\cdot$ & 5 \\
\hline 25 & Fraxinus caroliniana & $\cdot$ & - & $\cdot$ & $\cdot$ & - & - & - & - & $\cdot$ & - & - & $\cdot$ & - & $\cdot$ & - & - & $\cdot$ & 2 & - & - \\
\hline 24 & Fraxinus pennsylvanica & 10 & 15 & 15 & 2 & - & - & - & - & $\cdot$ & - & - & - & - & $\cdot$ & - & 2 & - & - & 3 & - \\
\hline 27 & llex opaca & $\cdot$ & 1 & $\cdot$ & $=$ & - & - & - & - & - & - & - & - & - & $\cdot$ & - & - & - & - & $\cdot$ & $\cdot$ \\
\hline 35 & Liquidambar styraciflua & $\cdot$ & 1 & 2 & 1 & - & - & $\cdot$ & - & - & $\cdot$ & - & - & - & $\cdot$ & - & - & 1 & 2 & - & 2 \\
\hline 34 & Magnolia virginiana & - & 5 & - & $\cdot$ & - & - & - & - & - & $\cdot$ & - & $\cdot$ & - & $\cdot$ & - & 3 & 1 & 3 & 2 & 1 \\
\hline 29 & Nyssa ogeche & - & 1 & - & - & 3 & - & $\cdot$ & - & - & - & - & - & - & - & - & 1 & - & 2 & - & 2 \\
\hline 74 & Pinus glabra & - & - & 1 & - & - & - & - & - & - & - & - & - & - & - & - & - & - & - & - & 1 \\
\hline 39 & Quercus laurifolia & $\cdot$ & - & - & - & - & - & - & - & $\cdot$ & $\cdot$ & - & $\cdot$ & - & - & $\cdot$ & $\cdot$ & 2 & $\cdot$ & - & - \\
\hline 163 & UImus americana & 5 & $\cdot$ & $\cdot$ & - & $\cdot$ & - & - & $\cdot$ & $\cdot$ & $\cdot$ & - & - & $\cdot$ & - & $\cdot$ & $\cdot$ & $\cdot$ & $\cdot$ & $\cdot$ & $\cdot$ \\
\hline
\end{tabular}


TABLE C.5 (Cont.)

\begin{tabular}{|c|c|c|c|c|c|c|c|c|c|c|c|c|c|c|c|c|c|c|c|c|c|}
\hline \multirow{3}{*}{$\begin{array}{l}\text { Field } \\
\text { Number }\end{array}$} & \multirow{3}{*}{$\begin{array}{l}\text { Species Name and } \\
\text { Authority }\end{array}$} & \multicolumn{20}{|c|}{ Areal Cover ${ }^{a}(\%)$} \\
\hline & & \multicolumn{5}{|c|}{ West Natural Area } & \multicolumn{5}{|c|}{ West ROW Area } & \multicolumn{5}{|c|}{ East ROW Area } & \multicolumn{5}{|c|}{ East Natural Area } \\
\hline & & T1 & $\mathrm{T} 2$ & T3 & $T_{4}$ & T5 & T1 & T2 & T3 & $\mathrm{T}_{4}$ & T5 & T1 & T2 & T3 & T4 & T5 & $\mathrm{T} 1$ & $\mathrm{~T} 2$ & T3 & T4 & T5 \\
\hline & TREESTRATUM & & & & & & & & & & & & & & & & & & & & \\
\hline 19 & Acer rubrum & 2344 & - & 7020 & - & - & - & - & - & - & - & - & - & - & - & - & 1895 & 4771 & 383 & - & 624 \\
\hline 25 & Fraxinus caroliniana & 204 & $\cdot$ & - & - & $\cdot$ & - & - & - & - & - & - & - & $\cdot$ & - & - & - & 765 & - & - & - \\
\hline 24 & Fraxinus pennsylvanica & 1090 & 156 & 421 & 1934 & 641 & $\cdot$ & - & $\cdot$ & - & $\cdot$ & - & - & - & - & - & 976 & 624 & 409 & $\cdot$ & - \\
\hline 35 & Liquidambar styraciflua & 1989 & 1833 & 3980 & 5039 & 2961 & - & - & - & - & $\cdot$ & - & - & - & - & - & 134 & 204 & 1911 & 1938 & 624 \\
\hline 34 & Magnolia virginiana & 287 & 1930 & - & - & - & - & - & - & $\cdot$ & - & $\cdot$ & $\cdot$ & - & - & - & 156 & - & - & 421 & 258 \\
\hline 29 & Nyssa ogecho & 3052 & 3647 & 522 & - & - & - & $\cdot$ & $\cdot$ & - & $\cdot$ & $\cdot$ & - & - & - & - & - & - & 2025 & 909 & 1312 \\
\hline 62 & Persea borbonia & - & 4476 & - & $\cdot$ & - & - & $\cdot$ & - & - & - & - & - & - & - & - & - & 2531 & - & - & - \\
\hline 74 & Pinus glabra & 872 & - & 716 & - & $\cdot$ & - & - & - & - & - & - & $\cdot$ & - & - & $\cdot$ & - & - & 2564 & $\cdot$ & $\cdot$ \\
\hline 39 & Quercus laurifolia & - & 287 & 2407 & 2585 & 2961 & - & - & $\cdot$ & - & - & - & - & - & - & - & 2784 & 2675 & 2331 & - & 8150 \\
\hline 98 & Taxodium distichum & - & - & - & - & - & - & $\cdot$ & - & $\cdot$ & - & - & $\cdot$ & - & - & - & - & 2235 & - & - & - \\
\hline \multirow[t]{2}{*}{163} & Ulmus americana & - & - & - & $\cdot$ & - & $\cdot$ & - & - & - & $\cdot$ & $\cdot$ & $\cdot$ & $\cdot$ & - & $\cdot$ & 258 & $\cdot$ & - & - & $\cdot$ \\
\hline & VINE STRATUM & & & & & & & & & & & & & & & & & & & & \\
\hline 78 & Decumaria barbara & - & $=$ & 2 & 1 & 2 & - & - & - & - & - & - & - & - & - & - & - & - & - & - & 1 \\
\hline 161 & Toxicodendron radicans & . & - & 3 & - & 1 & - & - & - & - & - & - & - & - & - & - & 1 & - & 1 & - & - \\
\hline 161 & Vitis rotundifolia & - & - & - & - & - & $\cdot$ & - & - & $\cdot$ & - & - & $\cdot$ & - & - & - & - & - & - & - & - \\
\hline
\end{tabular}

a Values are percent areal cover for herb, shrub, and sapling strata; total basal area for trees of that species in the plot; or number of vines per plot. 
TABLE C.6 Average Percent Cover, Absolute Frequencies, and Distribution of Species by Stratum, Brandy Branch Site

\begin{tabular}{|c|c|c|c|c|c|}
\hline \multirow[b]{2}{*}{$\begin{array}{l}\text { Field } \\
\text { Number }\end{array}$} & \multirow[b]{2}{*}{$\begin{array}{c}\text { Species Name and } \\
\text { Authoritiy }\end{array}$} & \multicolumn{4}{|c|}{$\begin{array}{c}\text { Average Percent Cover/ } \\
\text { Absolute Frequency }\end{array}$} \\
\hline & & WNA & $\begin{array}{l}\text { West } \\
\text { ROW }\end{array}$ & $\begin{array}{l}\text { East } \\
\text { ROW }\end{array}$ & ENA \\
\hline & Exposed soil & $0.0 / 0$ & $18.6 / 5$ & $10.6 / 5$ & $0.0 / 0$ \\
\hline & HERB STRATUM & & & & \\
\hline & Plants occurring in all four & & & & \\
\hline 12 & Cyperus virens & $1.0 / 1$ & $1.4 / 2$ & $8.4 / 3$ & $0.3 / 2$ \\
\hline 10 & Eupatorium capillifolium & $0.1 / 1$ & $0.2 / 2$ & $0.3 / 3$ & $0.2 / 1$ \\
\hline 5 & Gratiola virginana & $0.6 / 1$ & $4.1 / 5$ & $2.6 / 4$ & $-0.1 / 1$ \\
\hline 4 & Ludwigia repens & $2.7 / 4$ & $17.2 / 5$ & $21.1 / 5$ & $2.8 / 3$ \\
\hline 1 & Micranthemum umbrosum & $22.6 / 5$ & $40.0 / 5$ & $59.0 / 5$ & $4.6 / 3$ \\
\hline \multirow[t]{2}{*}{2} & Polygonum punctatum & $1.8 / 4$ & $2.2 / 3$ & $2.1 / 2$ & $0.7 / 3$ \\
\hline & Plants occurring in both $\mathrm{N}$ & and the & side of & OW & \\
\hline 11 & $\begin{array}{l}\text { Dichanthelium } \\
\text { dicotomum }\end{array}$ & $0.1 / 1$ & $0.6 / 2$ & $0.0 / 0$ & $1.1 / 2$ \\
\hline \multirow[t]{2}{*}{18} & Rhododendron canescens & $0.2 / 2$ & $0.1 / 1$ & $0.0 / 0$ & $1.0 / 2$ \\
\hline & Plants occurring in both $N$ & and the & side of $t$ & OW & \\
\hline 19 & Acer rubrum & $0.2 / 2$ & $0.0 / 0$ & $0.1 / 1$ & $1.2 / 3$ \\
\hline 49 & Boehmeria cylindrica & $0.1 / 1$ & $0.0 / 0$ & $0.1 / 1$ & $2.0 / 1$ \\
\hline \multirow[t]{2}{*}{33} & Justicia ovata & $18.6 / 4$ & $0.0 / 0$ & $0.3 / 2$ & $3.2 / 3$ \\
\hline & Plants occurring in both $\mathrm{N}$ & only & & & \\
\hline 22 & Carpinus caroliniana & $0.2 / 2$ & $0.0 / 0$ & $0.0 / 0$ & $0.3 / 2$ \\
\hline 38 & Hypoxis leptocarpa & $0.3 / 2$ & $0.0 / 0$ & $0.0 / 0$ & $0.1 / 1$ \\
\hline 27 & llex opaca & $0.1 / 1$ & $0.0 / 0$ & $0.0 / 0$ & $0.1 / 1$ \\
\hline 14 & Itea virginica & $0.1 / 1$ & $0.0 / 0$ & $0.0 / 0$ & $0.4 / 1$ \\
\hline 35 & Liquidambar styraciflua & $0.2 / 2$ & $0.0 / 0$ & $0.0 / 0$ & $0.1 / 1$ \\
\hline 16 & Lyonia lucida & $1.1 / 3$ & $0.0 / 0$ & $0.0 / 0$ & $2.1 / 2$ \\
\hline 39 & Quercus laurifolia & $0.4 / 4$ & $0.0 / 0$ & $0.0 / 0$ & $0.1 / 1$ \\
\hline \multirow[t]{2}{*}{21} & Smilax rotundifolia & $0.2 / 2$ & $0.0 / 0$ & $0.0 / 0$ & $0.1 / 1$ \\
\hline & Plants occurring in the Wh & ind both & s of the & & \\
\hline 64 & $\begin{array}{l}\text { Alternanthera } \\
\text { philoxeroides }\end{array}$ & $0.4 / 2$ & $7.0 / 2$ & $1.0 / 1$ & $0.0 / 0$ \\
\hline \multirow[t]{2}{*}{44} & Hypericum mutilum & $0.1 / 1$ & $0.2 / 1$ & $0.7 / 2$ & $0.0 / 0$ \\
\hline & Plants occurring in the WI & oniy & & & \\
\hline 55 & Crinum americanum & $1.0 / 1$ & $0.0 / 0$ & $0.0 / 0$ & $0.0 / 0$ \\
\hline 24 & Fraxinus pennsylvanica & $0.1 / 1$ & $0.0 / 0$ & $0.0 / 0$ & $0.0 / 0$ \\
\hline 34 & Magnolia virginiana & $2.0 / 1$ & $0.0 / 0$ & $0.0 / 0$ & $0.0 / 0$ \\
\hline 72 & Panicum maximum & $1.0 / 1$ & $0.0 / 0$ & $0.0 / 0$ & $0.0 / 0$ \\
\hline 36 & Polygonum setaceum & $0.1 / 1$ & $0.0 / 0$ & $0.0 / 0$ & $0.0 / 0$ \\
\hline 37 & Smilax smallii & $1.0 / 1$ & $0.0 / 0$ & $0.0 / 0$ & $0.0 / 0$ \\
\hline 161 & Toxicodendron radicans & $0.1 / 1$ & $0.0 / 0$ & $0.0 / 0$ & $0.0 / 0$ \\
\hline 54 & Vaccinium arboreum & $0.1 / 1$ & $0.0 / 0$ & $0.0 / 0$ & $0.0 / 0$ \\
\hline
\end{tabular}


TABLE C.6 (Cont.)

\begin{tabular}{|c|c|c|c|c|c|}
\hline \multirow[b]{2}{*}{$\begin{array}{l}\text { Field } \\
\text { Number }\end{array}$} & \multirow[b]{2}{*}{$\begin{array}{l}\text { Species Name and } \\
\text { Authoritiy }\end{array}$} & \multicolumn{4}{|c|}{$\begin{array}{c}\text { Average Percent Cover/ } \\
\text { Absolute Frequency }\end{array}$} \\
\hline & & WNA & $\begin{array}{l}\text { West } \\
\text { ROW }\end{array}$ & $\begin{array}{l}\text { East } \\
\text { ROW }\end{array}$ & ENA \\
\hline & \multicolumn{5}{|c|}{ Plant occurring in the ENA and both sides of the ROW } \\
\hline \multirow[t]{2}{*}{3} & Commelina diffusa & $0.0 / 0$ & $1.0 / 1$ & $1.0 / 1$ & $0.2 / 1$ \\
\hline & \multicolumn{5}{|c|}{ Plants occurring in the ENA and the east side of the ROW } \\
\hline \multirow[t]{2}{*}{13} & $\begin{array}{l}\text { Erechtites hieraciifolia } \\
\text { Ludwigia glandulosa }\end{array}$ & $\begin{array}{l}0.0 / 0 \\
0.0 / 0\end{array}$ & $\begin{array}{l}0.0 / 0 \\
0.0 / 0\end{array}$ & $\begin{array}{l}0.3 / 3 \\
0.1 / 1\end{array}$ & $\begin{array}{l}0.5 / 2 \\
0.5 / 2\end{array}$ \\
\hline & \multicolumn{5}{|c|}{ Plants occurring in the ENA only } \\
\hline 57 & Andropogon capillipes & $0.0 / 0$ & $0.0 / 0$ & $0.0 / 0$ & $0.1 / 1$ \\
\hline 17 & Carex debilis & $0.0 / 0$ & $0.0 / 0$ & $0.0 / 0$ & $0.2 / 2$ \\
\hline 83 & Carex glaucescens & $0.0 / 0$ & $0.0 / 0$ & $0.0 / 0$ & $2.0 / 1$ \\
\hline 75 & $\begin{array}{l}\text { Cephalanthus } \\
\text { occidentalis }\end{array}$ & $0.0 / 0$ & $0.0 / 0$ & $0.0 / 0$ & $0.1 / 1$ \\
\hline 31 & Decumaria barbara & $0.0 / 0$ & $0.0 / 0$ & $0.0 / 0$ & $0.1 / 0$ \\
\hline 58 & Diodia virginiana & $0.0 / 0$ & $0.0 / 0$ & $0.0 / 0$ & $0.2 / 2$ \\
\hline 73 & Hydrocotyle umbellata & $0.0 / 0$ & $0.0 / 0$ & $0.0 / 0$ & $1.6 / 1$ \\
\hline 20 & Mitchella repens & $0.0 / 0$ & $0.0 / 0$ & $0.0 / 0$ & $0.1 / 1$ \\
\hline 77 & Rubus argutus & $0.0 / 0$ & $0.0 / 0$ & $0.0 / 0$ & $0.2 / 2$ \\
\hline 15 & Smilax laurifolia & $0.0 / 0$ & $0.0 / 0$ & $0.0 / 0$ & $0.4 / 1$ \\
\hline 76 & Triadenum walteri & $0.0 / 0$ & $0.0 / 0$ & $0.0 / 0$ & $0.6 / 1$ \\
\hline 56 & Vaccinium fuscatum & $0.0 / 0$ & $0.0 / 0$ & $0.0 / 0$ & $0.1 / 1$ \\
\hline 60 & Vitis rotundifolia & $0.0 / 0$ & $0.0 / 0$ & $0.0 / 0$ & $2.0 / 1$ \\
\hline \multirow[t]{3}{*}{59} & Woodwardia virginica & 0.010 & $0.0 / 0$ & $0.0 / 0$ & $0.1 / 1$ \\
\hline & & $0.0 / 0$ & $0.0 / 0$ & $0.0 / 0$ & $0.1 / 1$ \\
\hline & \multicolumn{5}{|c|}{ Plants occurring in both sides of the ROW } \\
\hline 7 & Cyperus distinctus & & & & \\
\hline 71 & Echinochloa walteri & $0.0 / 0$ & $2.0 / 1$ & $2.0 / 3$ & $0.0 / 0$ \\
\hline 66 & Fimbristylis autumnalis & $0.0 / 0$ & $0.1 / 1$ & $3.1 / 2$ & $0.0 / 0$ \\
\hline 67 & Pluchea camphorata & $0.0 / 0$ & $0.2 / 1$ & $3.5 / 3$ & $0.0 / 0$ \\
\hline \multirow[t]{3}{*}{9} & Typha latifolia & $0.0 / 0$ & $0.1 / 1$ & $0.2 / 2$ & $0.0 / 0$ \\
\hline & & $0.0 / 0$ & $0.1 / 1$ & $0.2 / 2$ & $0.0 / 0$ \\
\hline & \multicolumn{5}{|c|}{ Plants occurring in the west side of the ROW only } \\
\hline 53 & Myriophyllum brasiliense & & & & \\
\hline \multirow[t]{3}{*}{41} & Pontederia cordata & $0.0 / 0$ & $2.0 / 1$ & $0.0 / 0$ & $0.0 / 0$ \\
\hline & & $0.0 / 0$ & $1.0 / 1$ & $0.0 / 0$ & $0.0 / 0$ \\
\hline & \multicolumn{5}{|c|}{ Plants occurring in the east side of the ROW only } \\
\hline 69 & Carex albolutescens & & & & \\
\hline 85 & Cyperus tenuifolius & $0.0 / 0$ & $0.0 / 0$ & $1.4 / 1$ & $0.0 / 0$ \\
\hline 65 & Digitaria serotina & $0.0 / 0$ & $0.0 / 0$ & $0.2 / 1$ & $0.0 / 0$ \\
\hline 46 & Eleocharis microcarpa & $0.0 / 0$ & $0.0 / 0$ & $0.4 / 1$ & $0.0 / 0$ \\
\hline 45 & Eleocharis tuberculosa & $0.0 / 0$ & $0.0 / 0$ & $0.1 / 1$ & $0.0 / 0$ \\
\hline 50 & Fuirena breviseta & $0.0 / 0$ & $0.0 / 0$ & $1.4 / 1$ & $0.0 / 0$ \\
\hline 6 & Iris hexagona & $0.0 / 0$ & $0.0 / 0$ & $5.6 / 2$ & $0.0 / 0$ \\
\hline 47 & Juncus repens & $0.0 / 0$ & $0.0 / 0$ & $0.1 / 1$ & $0.0 / 0$ \\
\hline 88 & Ludwigia sp. & $0.0 / 0$ & $0.0 / 0$ & $0.2 / 1$ & $0.0 / 0$ \\
\hline 51 & Mikania scandens & $0.0 / 0$ & $0.0 / 0$ & $0.1 / 1$ & $0.0 / 0$ \\
\hline 89 & Panicum hemitomon & $0.0 / 0$ & $0.0 / 0$ & $0.1 / 1$ & $0.0 / 0$ \\
\hline 42 & Paspalum notatum & $0.0 / 0$ & $0.0 / 0$ & $0.4 / 1$ & $0.0 / 0$ \\
\hline 70 & $\begin{array}{l}\text { Rhynchospora } \\
\text { microcephala }\end{array}$ & $0.0 / 0$ & $0.0 / 0$ & $8.0 / 1$ & 0.010 \\
\hline 48 & Salix nigra & $0.0 / 0$ & $0.0 / 0$ & $1.6 / 1$ & $0.0 / 0$ \\
\hline 43 & Scirpus cyperinus & $0.0 / 0$ & $0.0 / 0$ & $0.2 / 2$ & $0.0 / 0$ \\
\hline & & $0.0 / 0$ & $0.0 / 0$ & $0.2 / 1$ & $0.0 / 0$ \\
\hline
\end{tabular}


TABLE C.6 (Cont.)

\begin{tabular}{|c|c|c|c|c|c|}
\hline \multirow[b]{2}{*}{$\begin{array}{l}\text { Field } \\
\text { Number }\end{array}$} & \multirow[b]{2}{*}{$\begin{array}{c}\text { Species Name and } \\
\text { Authoritiy }\end{array}$} & \multicolumn{4}{|c|}{$\begin{array}{c}\text { Average Percent Cover/ } \\
\text { Absolute Frequency }\end{array}$} \\
\hline & & WNA & $\begin{array}{l}\text { West } \\
\text { ROW }\end{array}$ & $\begin{array}{l}\text { East } \\
\text { ROW }\end{array}$ & ENA \\
\hline & \multicolumn{5}{|c|}{ Plants occurring within the site but not in the sample plots } \\
\hline 32 & Asclepias perennis & & & & \\
\hline 82 & Carex lurida & $0.0 / 0$ & $0.0 / 0$ & $0.0 / 0$ & $0.0 / 0$ \\
\hline 81 & Carex $\times$ stipata & $0.0 / 0$ & $0.0 / 0$ & $0.0 / 0$ & $0.0 / 0$ \\
\hline 61 & Centella asiatica & $0.0 / 0$ & $0.0 / 0$ & $0.0 / 0$ & $0.0 / 0$ \\
\hline 94 & Chasmanthium laxum & $0.0 / 0$ & $0.0 / 0$ & $0.0 / 0$ & $0.0 / 0$ \\
\hline 92 & Eichhomia crassipes & $0.0 / 0$ & $0.0 / 0$ & $0.0 / 0$ & $0.0 / 0$ \\
\hline 87 & Erigeron vernus & $0.0 / 0$ & $0.0 / 0$ & $0.0 / 0$ & $0.0 / 0$ \\
\hline 91 & Juncus effusus & $0.0 / 0$ & $0.0 / 0$ & $0.0 / 0$ & $0.0 / 0$ \\
\hline 84 & Juncus polycephalus & $0.0 / 0$ & $0.0 / 0$ & $0.0 / 0$ & $0.0 / 0$ \\
\hline 93 & Nyssa ogeche & $0.0 / 0$ & $0.0 / 0$ & $0.0 / 0$ & $0.0 / 0$ \\
\hline 63 & Saururus cemuus & $0.0 / 0$ & $0.0 / 0$ & $0.0 / 0$ & $0.0 / 0$ \\
\hline 79 & Woodwardia areolata & $0.0 / 0$ & $0.0 / 0$ & $0.0 / 0$ & $0.0 / 0$ \\
\hline \multirow[t]{4}{*}{90} & Xyris jupicai & $0.0 / 0$ & $0.0 / 0$ & $0.0 / 0$ & $0.0 / 0$ \\
\hline & & $0.0 / 0$ & $0.0 / 0$ & $0.0 / 0$ & $0.0 / 0$ \\
\hline & SHRUB STRATUM & & & & \\
\hline & Plants occurring in both NAs & & & & \\
\hline 19 & Acer rubrum & $0.2 / 1$ & $0.0 / 0$ & $0.0 / 0$ & $0.2 / 1$ \\
\hline 22 & Carpinus caroliniana & $3.6 / 5$ & $0.0 / 0$ & $0.0 / 0$ & $11.4 / 5$ \\
\hline 40 & Cyrilla racemiflora & $0.8 / 3$ & $0.0 / 0$ & $0.0 / 0$ & $1.0 / 2$ \\
\hline 25 & Fraxinus caroliniana & $1.8 / 3$ & $0.0 / 0$ & $0.0 / 0$ & $1.0 / 1$ \\
\hline 24 & Fraxinus pennsylvanica & $3.6 / 2$ & $0.0 / 0$ & $0.0 / 0$ & $0.7 / 3$ \\
\hline 27 & llex opaca & $0.8 / 1$ & $0.0 / 0$ & $0.0 / 0$ & $0.8 / 3$ \\
\hline 26 & Leucothoe racemosa & $0.1 / 1$ & $0.0 / 0$ & $0.0 / 0$ & $0.2 / 1$ \\
\hline 35 & Liquidambar styraciflua & $0.3 / 2$ & $0.0 / 0$ & $0.0 / 0$ & $1.6 / 2$ \\
\hline 16 & Lyonia lucida & $0.2 / 1$ & $0.0 / 0$ & $0.0 / 0$ & $0.6 / 1$ \\
\hline 34 & Magnolia virginiana & $0.6 / 2$ & $0.0 / 0$ & $0.0 / 0$ & $0.6 / 2$ \\
\hline 29 & Nyssa ogeche & $1.0 / 3$ & $0.0 / 0$ & $0.0 / 0$ & $0.2 / 1$ \\
\hline \multirow[t]{2}{*}{56} & Vaccinium fuscatum & $0.1 / 1$ & $0.0 / 0$ & $0.0 / 0$ & $0.1 / 1$ \\
\hline & \multicolumn{5}{|c|}{ Plant occurring in the WNA only } \\
\hline \multirow[t]{2}{*}{18} & Rhododendron canescens & $0.2 / 1$ & $0.0 / 0$ & 0.010 & $0.0 / 0$ \\
\hline & \multicolumn{5}{|c|}{ Plants occurring in the ENA only } \\
\hline 28 & Myrica cerifera & $0.0 / 0$ & $0.0 / 0$ & $0.0 / 0$ & $0.2 / 1$ \\
\hline \multirow[t]{2}{*}{30} & Quercus michauxii & $0.0 / 0$ & $0.0 / 0$ & $0.0 / 0$ & $0.2 / 2$ \\
\hline & \multicolumn{5}{|c|}{ Plant occurring within the site but not in sample plots } \\
\hline \multirow[t]{3}{*}{14} & Itea virginica & $0.0 / 0$ & $0.0 / 0$ & $0.0 / 0$ & $0.0 / 0$ \\
\hline & SAPLING STRATUM & & & & \\
\hline & \multicolumn{5}{|l|}{ Plants occurring in both NAs } \\
\hline 19 & Acer rubrum & $0.4 / 2$ & $0.0 / 0$ & $0.0 / 0$ & $0.8 / 1$ \\
\hline 22 & Carpinus caroliniana & $0.4 / 1$ & $0.0 / 0$ & $0.0 / 0$ & $1.0 / 1$ \\
\hline 24 & Fraxinus pennsylvanica & $8.4 / 4$ & $0.0 / 0$ & $0.0 / 0$ & $1.0 / 2$ \\
\hline 35 & Liquidambar styraciflua & $0.8 / 3$ & $0.0 / 0$ & $0.0 / 0$ & $1.0 / 3$ \\
\hline 34 & Magnolia virginiana & $1.0 / 1$ & $0.0 / 0$ & $0.0 / 0$ & $2.0 / 5$ \\
\hline 29 & Nyssa ogeche & $0.8 / 2$ & $0.0 / 0$ & $0.0 / 0$ & $1.0 / 3$ \\
\hline 74 & Pinus glabra & $0.2 / 1$ & $0.0 / 0$ & $0.0 / 0$ & $0.2 / 1$ \\
\hline
\end{tabular}


TABLE C.6 (Cont.)

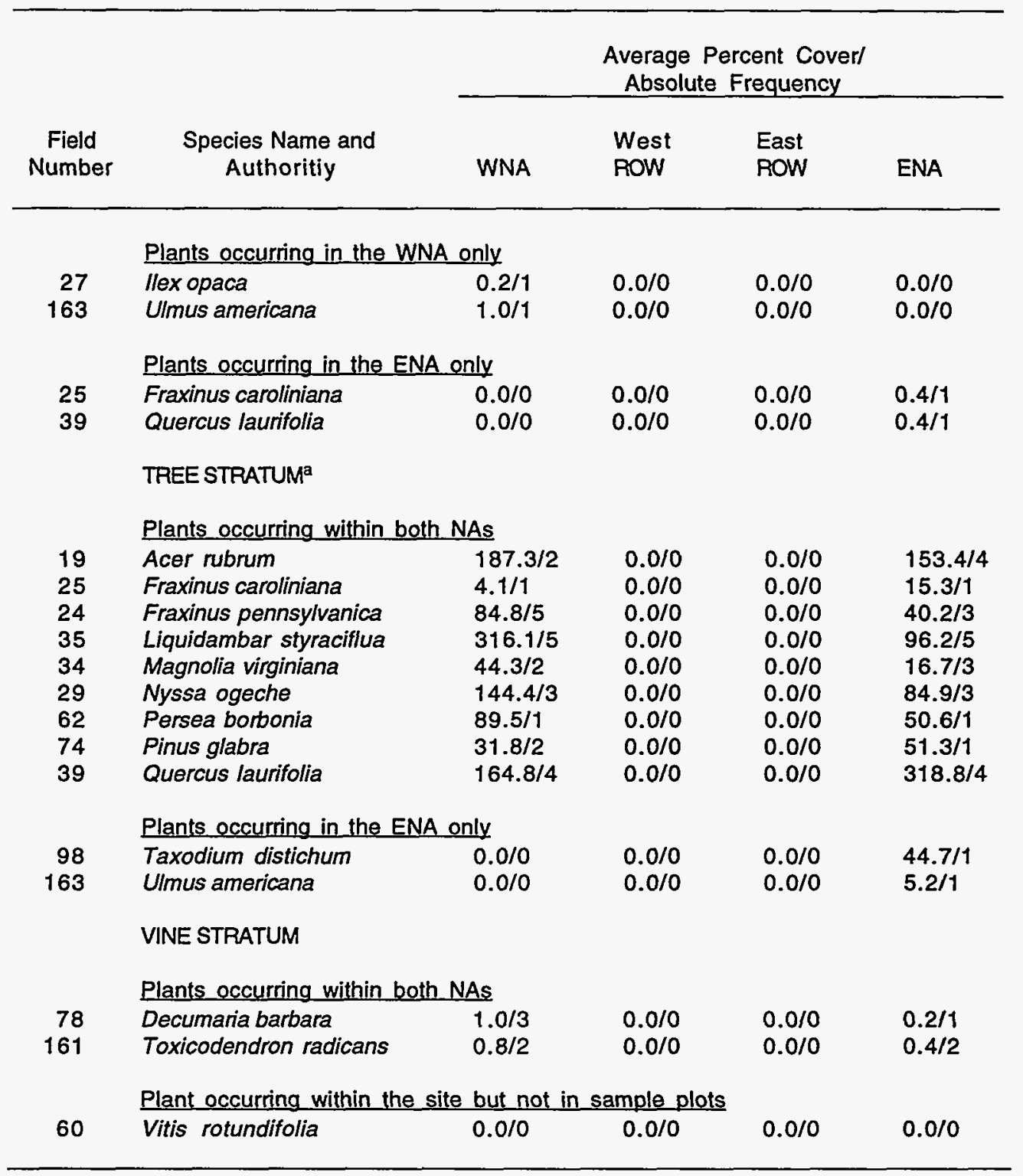

a Numbers for trees indicate average basal areas over numbers of plots in which they occurred. 